CARlos Augusto de Miranda e MARTins

RACISMO ANUNCIADO:

o negro e a publicidade no Brasil
1985-2005 
Carlos Augusto de Miranda e Martins

\section{Racismo Anunciado: o negro e a publicidade no Brasil (1985-2005)}

Dissertação apresentada ao Programa de Pós-Graduação em Ciências da Comunicação da Universidade de São Paulo, área de concentração III - Interfaces Sociais da Comunicação, como requisito parcial para obtenção do título de Mestre em Ciências da Comunicação.

Orientadora: Profa. Dra. Solange Martins Couceiro de Lima

São Paulo 2009 

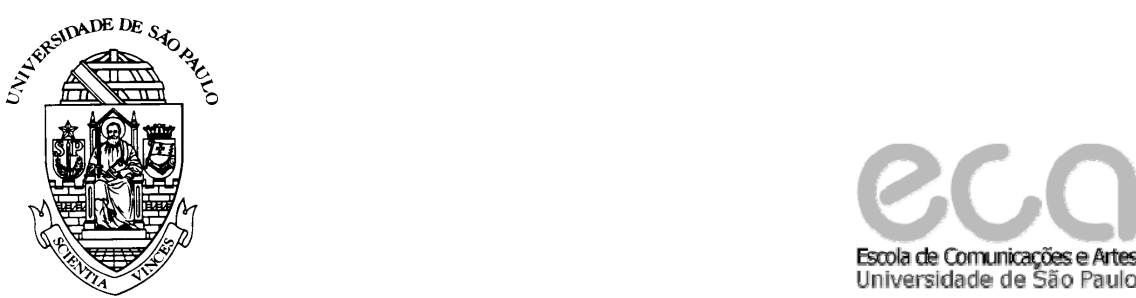

Capa*: Carina Nascimento

Revisão: Wany Martinho e Cláudia Dunder

*Foto gentilmente cedida pela atriz Cinthya Rachel, a quem agradecemos.

Martins, Carlos Augusto de Miranda e

Racimo anunciado: o negro e a publicidade no Brasil (1985-2005) /

Carlos Augusto de Miranda e Martins. - São Paulo: C. A. M. Martins, 2009.

115.: il. + CD-ROM.

Dissertação (Mestrado) - Departamento de Comunicações e Artes / Escola

de Comunicações e Artes/USP.

Orientadora: Profa. Dra. Solange Martins Couceiro de Lima.

Bibliografia

1. Meios de Comunicação - Brasil 2. Publicidade - Brasil 3. Relações Raciais - Brasil

4. Racismo - Brasil 5. Negros e afrodescendentes - Brasil 6. Estereótipos

7. Representaç̃̃es I. Couceiro de Lima, Solange Martins II. Universidade de São Paulo III. Título.

CDD 21.ed. -306

Autorizo a reprodução e divulgação total ou parcial deste trabalho, por qualquer meio convencional ou eletrônico, para fins de estudo e pesquisa, desde que citada a fonte e observada a legislação referente à propriedade intelectual e direitos autorais. 
Racismo Anunciado: o negro e a publicidade no Brasil (1985-2005)

Carlos Augusto de Miranda e Martins

Dissertação apresentada à Escola de Comunicação e Artes da Universidade de São Paulo como requisito parcial para obtenção do título de Mestre em Ciências da Comunicação.

Aprovado em:

Banca examinadora: 
José Carlos Martins (in memorian)

Veralucia Miranda Martins Marina de Miranda e Martins 


\section{AGRADECIMENTOS}

À minha mãe Veralucia, cujo apoio, incentivo e dedicação não poderei retribuir em uma só encarnação; à minha irmã Marina e ao meu tio Geraldo Martins;

À Profa. Dra. Solange Couceiro, minha orientadora, pela paciência e atenção dispensadas em todos esses anos de elaboração e execução do projeto; à Profa. Dra. Rosana Soares; à Profa. Dra. Dilma de Melo Silva ao Prof. Dr. Ricardo Alexino, à Profa. Dra. Maria Immacolata Vassallo de Lopes; e à Profa. Roberta Brandalise;

Na Argentina, meus agradecimentos à Profa. Dra. Vanina Papalini, minha co-orientadora, pela prestatividade e atenção em todo o processo que envolveu minha estância na Universidade Nacional de Córdoba, ao Prof. Magter. Eduardo Zabatel, da Cátedra de Estudos Brasileiros da Universidade de Buenos Aires (UBA); à Profa. Laura Zambrini (UBA); e ao Prof. Dr. Carlos Hasenbalg;

Gostaria de agradecer também o Centro de Estudos Afro-Asiáticos da Universidade Federal da Bahia, em especial à Profa. Dra. Ângela Figueiredo, coordenadora do Curso Internacional Avançado de Relações Raciais e Cultura Negra, por toda a vivência proporcionada pelo programa;

Por fim, agradeço às pessoas que de alguma maneira tiveram participação fundamental na realização dessa pesquisa: Kelly Dunder, minha namorada, Carlos Rogério Gonçalves, Juliana Serzedello, Eliane Costa, Carina Nascimento, Ricardo Inamine e Cláudia Beck Inamine, Altair Freitas, Daniela Torres, Tatiana Pacheco, Wany Martinho, Sandra Mascarenhas, Vera Coppola, Marco Antonio Aleixo, Família Toida, Cezar Telles, Cristina Topa, Raphael Sayeg e Beatriz Cortez e Lucimar Felisberto. E mesmo sem necessidade ou cabimento, agradeço pessoas que num passado não tão distante colaboraram muito com esse trabalho;

O presente trabalho foi realizado com apoio financeiro da Rede de Macro Universidades da América Latina e Caribe (RedMacro), à qual também agradecemos. 
Precisamos entender melhor como o racismo opera, desvendando suas raízes intelectuais e demonstrando ponto por ponto a sua dinâmica e metamorfose contemporânea a fim de desenvolver novas estratégias para combatê-lo.

Kabengele Munanga 
RESUMO: O presente trabalho tem como principal objetivo estudar a participação do negro na publicidade brasileira entre os anos de 1985 e 2005, buscando não apenas mensurar sua presença nos anúncios desse período, mas também identificar e analisar os estereótipos mais comuns sob os quais aparece representado. A hipótese que buscamos comprovar é a de que a imagem do negro na publicidade do final do século XX e início do século XXI é baseada em representações pejorativas e subalternizantes construídas socialmente ainda no século XIX. Para tanto, iniciamos nossa dissertação examinando o surgimento do pensamento racista no Brasil (por volta de 1850) e sua conseqüente materialização em projetos políticos conservadores e eugenistas que tinham como meta a constituição de um país branco. Num segundo momento, procuramos trabalhar com a influência desse pensamento na produção cultural oitocentista - com especial atenção à literatura, à imprensa escrita e aos anúncios de jornal - discutindo também os modos de consolidação e perpetuação dos estereótipos no transcorrer do século XX. O passo seguinte consistiu na análise das imagens que compõe nossa amostra, buscando apontar rupturas e permanências tanto em relação ao passado oitocentista como dentro do balizamento proposto. A escolha do período indicado (19852005) deu-se em razão de sua importância no contexto da luta anti-racista, e nossa amostra teve como fonte documental a revista Veja, tendo em vista a relevância da publicação e também o grande valor que certas pesquisas conferem à publicidade veiculada em revistas. Por fim, convém esclarecer que o foco na publicidade deve-se à importância desse segmento no universo dos meios de comunicação, seja como esteio financeiro, seja como vetor de idéias e comportamentos.

Palavras-chave: Meios de Comunicação - Brasil; Publicidade - Brasil; Relações Raciais Brasil; Racismo - Brasil; Negros e afrodescendentes - Brasil; Estereótipos; Representações.

ABSTRACT: This presented work has as a main objective the study of the Afro-Americans participation in Brazilian advertisement from years 1985 to 2005, searching not only their appearance in advertisement during this period, but also identifying and analising the most common stereotypes they are impersonating. The hypothesis we want to prove is that the black people image presented in advertisement from the end of the 20th century to the beginning of the 21st century is based upon depreciative and subalterning representations socially built during the 19th century. To do so, we will start our dissertation examining the arise of racist thoughts in Brazil (circa 1850) and the outcome as eugenist and conservative political projects that had a formation of a white country as their target. Hereafter, we will work about the influence of these thoughts in the cultural production of the 19th century with special focus to literature, press, and newspaper advertisements - also debating the consolidating and perpetuating means of the stereotypes through the 20th century. The following step consisted in the analysis of those images that make our sample, searching breaches and remainings not only related to the 19th century past but also inside the proposed framework. The chosen period (1985-2005) is related to the importance in the anti-racist fight context, and our sample had as the main documental source "Veja" magazine, not only because of the publication weightiness, but also for the importance of certain researches give to advertisements carried in magazines. Lastly, shall we clarify that the centre of interest is advertisement due to the importance given for this industry among the communication means as a whole, as a financial prop or as a ideas and behavior agent.

Key-words: Communication Means - Brazil; Advertisement - Brazil, Racial Relations Brazil; Racism - Brazil; Black people and afro-americans - Brazil; Stereotypes, Representations. 
RESUMEN: El presente trabajo tiene como principal objetivo estudiar la participación de los negros en la publicidad brasileña entre los años 19852 2005, buscando no sólo mensurar su presencia en los anuncios del periodo, pero también identificar y analizar los estereotipos más comunes bajo aparecen representados. La hipótesis que intentamos comprobar es que la imagen de los negros en la publicidad de fines del siglo XX y comienzo del siglo XXI está basada en representaciones peyorativas y subalternizantes socialmente construidas en el siglo XIX. Para logar eso empezamos por examinar el surgimiento del pensamiento racista en Brasil (cerca del año 1850) y su consecuente materialización en proyectos políticos conservadores y eugenesistas que tenían como objetivo la construcción de un país blanco. En un segundo momento, buscamos trabajar con la influencia de ese pensamiento en la producción cultural de los años 1800 - con especial atención a la literatura de ficción, a la prensa escrita y a los anuncios de periódicos - discutiendo también los modos de consolidación y perpetuación de eses estereotipos durante el siglo XX. El paso siguiente se constituyo en la analice de las imágenes que componen nuestra muestra, procurando apuntar rupturas y permanencias tanto con relación a los años 1800 como dentro del periodo propuesto. Elegimos el período indicado (1985-2005) por su importancia en el contexto de la lucha anti-racista, y nuestra muestra tuvo como fuente documental la revista semanal Veja, teniendo en cuenta la preeminencia de la publicación y también la importancia que determinadas investigaciones confieren a la publicidad vehiculada en revistas. Por fin, conviene aclarar que el foco en la publicidad se debe a la relevancia de ese segmento en el universo de los medios de comunicación, tanto como financiero, como vector de ideas y comportamientos.

Palabras-clave: Medios de comunicación - Brasil; Publicidad - Brasil; Relaciones Raciales Brasil; Racismo - Brasil; Negros y afrodescendientes - Brasil; Estereotipos; Representaciones. 


\section{SUMÁRIO}

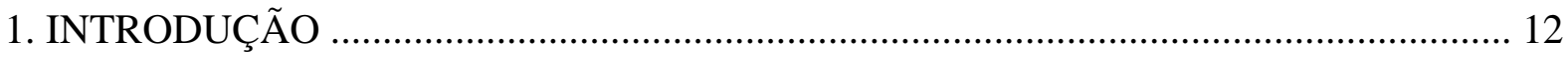

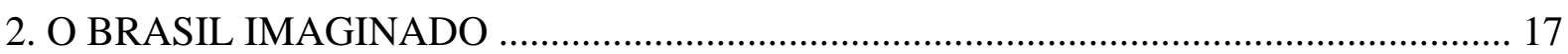

2.1 - Os projetos políticos de Brasil ....................................................................... 24

2.2 - Abolição, imigração e branqueamento ............................................................. 30

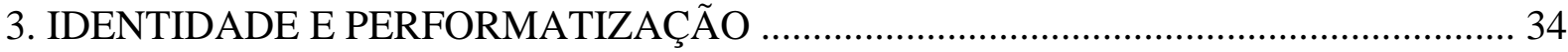

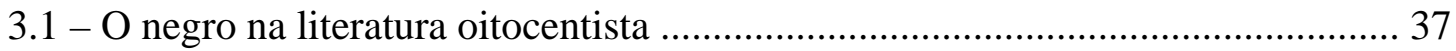

3.2 - O negro e a imprensa do século XIX …........................................................... 42

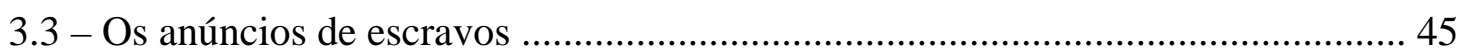

3.4 - O século XX e o registro branco do Brasil ......................................................... 50

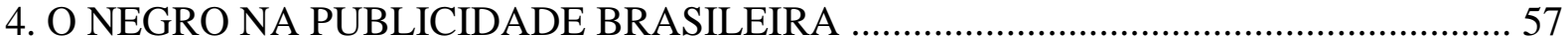

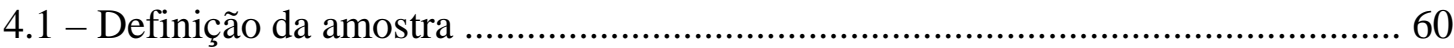

4.2 - Observação e tratamento das fontes ................................................................... 62

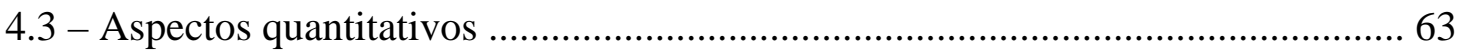

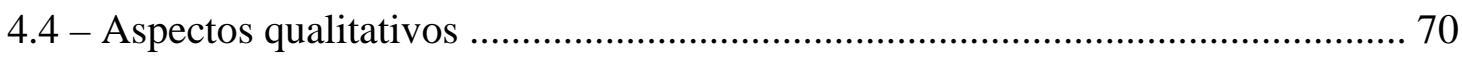

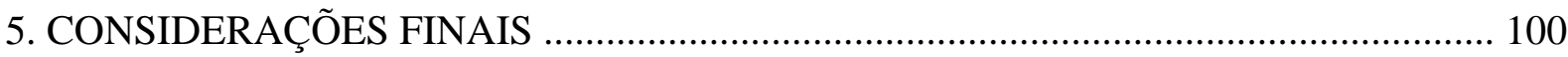

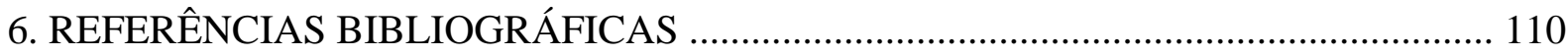

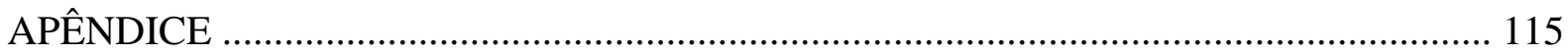




\section{INTRODUÇÃO}

...entro em cena com a vida em jogo, aceito o desafio da folha em branco... Paulo Augusto de Lima

Em seu livro A Cultura da Mídia, Douglas Kellner afirma que as narrativas e as imagens veiculadas pelos meios de comunicação são elementos que "ajudam a urdir o tecido da vida cotidiana”, não apenas fornecendo os símbolos, os mitos e os recursos que ajudam a construir uma cultura comum para a maioria dos indivíduos, mas fornecendo também o material com que as pessoas forjam as identidades pelas quais se inserem nas sociedades tecnocapitalistas (KELLNER, 2001, p.9):

O rádio, a televisão, o cinema e os outros produtos da indústria cultural fornecem os modelos daquilo que significa ser homem ou mulher, bemsucedido ou fracassado, poderoso ou impotente. A cultura da mídia também fornece o material com que muitas pessoas constroem o seu senso de classe, de etnia e raça, de nacionalidade, de sexualidade, de "nós" e "eles" (KELLNER, 2001, p.9).

Da mesma forma, os meios de comunicação ajudariam a modelar as opiniões políticas e os comportamentos sociais, definindo o que é considerado bom ou mau, positivo ou negativo, moral ou imoral. E mais do que isso: os espetáculos midiáticos demonstrariam quem tem e quem não tem poder, quem pode e quem não pode exercer força e violência. Em outras palavras, dramatizariam e legitimariam as relações de poder vigentes (KELLNER, 2001, p.9-10).

Nesse sentido, o autor entende que a cultura da mídia "é um terreno de disputa, no qual, grupos sociais importantes e ideologias rivais lutam pelo domínio”, luta essa que os indivíduos vivenciam "por meio de imagens, discursos, mitos e espetáculos veiculados pela mídia”. (KELLNER, 2001, p.11).

Assim, partindo do "pressuposto de que sociedade e cultura são terrenos de disputa e de que as produções culturais nascem e produzem efeitos em determinados contextos”, Kellner realiza um estudo cultural crítico da cultura da mídia: "Um estudo cultural crítico conceitua a sociedade como um terreno de dominação e resistência, fazendo uma crítica da dominação e dos modos como a cultura veiculada pela mídia se empenha em reiterar as relações de dominação e opressão (KELLNER, 2001, p.12-13).

No caso do Brasil, a questão racial é uma das principais (se não a principal) causas de disputas e conflitos. Estudos como os realizados pelo Instituto de Pesquisas Econômicas Aplicadas (IPEA) comprovam que apesar de não haver no país uma política positivada de apartheid, o segmento negro da população sofre severas restrições no que tange ao acesso a 
bens materiais e serviços públicos.

Dados referentes a 2007 nos mostram, por exemplo, que os negros - 49,8\% da população - correspondem a $67 \%$ das pessoas situadas na faixa dos $10 \%$ mais pobres do país, número que cai para $21 \%$ quando se consideram os $10 \%$ mais ricos. Nesse mesmo ano enquanto $20 \%$ da população branca situava-se abaixo da linha de pobreza, esse número entre os negros era de $41 \%$. No caso da situação de indigência observamos o mesmo: 6\% de brancos contra 17\% de negros: "Isso significa 20 milhões a mais de negros pobres do que brancos e 9,5 milhões de indigentes negros a mais do que brancos (PINHEIRO, 2008, p.33).

Se olharmos para os dados referentes ao mercado de trabalho também encontraremos graves distorções. Ainda com respeito a 2007, os números revelam que do total de desocupados $^{1}$ no país $54 \%$ eram negros e $45 \%$ brancos, isso sem falar na precariedade, já que se observarmos, por exemplo, as proporções de homens brancos e negros que trabalham sem carteira assinada veremos que os números são de $16 \%$ e $23 \%$ respectivamente (PINHEIRO, 2008, p.24).

Os números relativos à renda vão nessa mesma linha: a renda média do trabalhador negro equivale a aproximadamente $54 \%$ do rendimento médio de um trabalhador branco, sendo que as mulheres negras acabam sendo duplamente penalizadas, vez que têm seu rendimento inferior ao da mulher branca e ao do homem negro (PINHEIRO, 2008, p.33).

Como conseqüência das desigualdades educacionais, da segregação de mulheres e negros em postos de trabalho de menor qualidade e do próprio fenômeno social da discriminação, os rendimentos de homens e de brancos tendem a ser mais elevados do que o de mulheres e negros. Com efeito, em 2007, enquanto as mulheres brancas ganhavam, em média, 62,3\% do que ganhavam homens brancos, as mulheres negras ganhavam $67 \%$ do que recebiam os homens do mesmo grupo racial e apenas 34\% do rendimento médio de homens brancos (PINHEIRO, 2008, p.33).

A propósito, cabe dizer que a média de anos de estudo para pessoas com 15 anos de idade ou mais é maior entre os brancos (8,1 anos) que entre os negros (6,3 anos), da mesma forma que as taxas de analfabetismo: $6 \%$ entre brancos e $14 \%$ entre negros (PINHEIRO, 2008).

Mas as dificuldades da população negra não se restringem ao âmbito material, repercutindo também no "mercado" de bens simbólicos. Ou seja, todos os lugares de representação simbólica, como espaços públicos, livros didáticos, produções artísticas e, em especial, os meios de comunicação, acabam por reproduzir a segregação presente nos demais setores da sociedade:

\footnotetext{
${ }^{1}$ Pessoas desocupadas: são aquelas que não tinham trabalho, na semana de referência, mas estavam dispostas a trabalhar e que, para isso, tomaram alguma providência efetiva (PINHEIRO, 2008).
} 
Discutir as dinâmicas da mídia frente às questões de raça e etnicidade é, em grande medida, discutir as matrizes do racismo no Brasil. Os meios de comunicação são, por assim dizer, um caso-modelo de reprodução das nossas relações raciais (RAMOS, 2002, p.9).

No universo das mídias, a publicidade assume relevância que extrapola sua função de estímulo e incentivo ao consumo. Para além de seu papel precípuo, está não apenas sua importância econômica ${ }^{2}$, mas também o fato de ser ela um dos mais eficientes vetores de discursos e mensagens simbólicas. De acordo com os argumentos de Kellner, a publicidade nos "vende produtos e visões de mundo por meio de imagens, retórica e slogans justapostos em anúncios nos quais são postos em ação recursos artísticos psicológicos e mercadológicos” (KELLNER, 2001, p.322).

...a propaganda "interpela" os indivíduos e convida-os a identificar-se com produtos, imagens e comportamentos. Apresenta uma imagem utópica de novidade, sedução, sucesso e prestígio mediante a compra de certos bens. (...) Por conseguinte, os indivíduos aprendem a identificar-se com valores, modelos e comportamentos sociais através da propaganda, que é portanto, um importante instrumento de socialização ao mesmo tempo que determina a demanda do consumidor (KELLNER, 2001, p.322).

Considerando então o contexto histórico-social brasileiro, e tendo em vista a influência que a publicidade pode exercer, buscamos realizar um trabalho que, de alguma forma, se posicionasse como um estudo cultural crítico da mídia nacional.

Assim, no capítulo 2 procuramos examinar de que maneira o conceito de raça (bem como as teorias raciais) foi introduzido no Brasil durante o século XIX, e como esse novo paradigma “científico" - que "atestava” a inferioridade ontológica da raça negra - concorreu para a formação de um pensamento racista no país e orientou a construção da identidade nacional brasileira.

No capítulo 3 nosso objetivo foi analisar a reverberação desse pensamento racista nas diferentes formas de produção cultural não só no século XIX, mas também nas primeiras décadas do século XX - com especial atenção à literatura ficcional e à imprensa escrita. Recorrendo a autores que se dedicaram ao estudo da imagem pública do negro nesse período fomos capazes de apontar os principais estereótipos sob os quais o negro aparecia representado e verificar que quase todos traziam consigo forte conotação negativa.

Já no capítulo 4 entramos na questão da publicidade propriamente dita. É o momento em que apresentamos dados quantitativos sobre a presença do negro na publicidade brasileira, assim como realizamos a análise qualitativa da amostra, buscando comparar a imagem pública

\footnotetext{
2 "Na verdade, seria impossível considerarmos o advento de uma indústria cultural sem levarmos em conta o avanço da publicidade; em grande parte, é através dela que todo o complexo de comunicação se mantém. O caso brasileiro não foge à regra” (ORTIZ, 2001, p.130).
} 
contemporânea do negro às imagens historicamente atribuídas ao grupo, identificando assim continuidades e rupturas.

A hipótese que procuramos comprovar é a de que a despeito de toda a luta anti-racista levada a cabo pelo movimento negro, por setores da Academia, por intelectuais e até mesmo pelo poder público, a imagem do negro veiculada pela publicidade mais atual é ainda baseada nos mesmos estereótipos forjados para o negro no século XIX.

Convém dizer que no âmbito dessa pesquisa o estereótipo é tratado como uma “percepção social falsa” fruto de um "processo de facilitação e inércia” que ocorre durante aquilo que Ecléa Bosi chama de "trabalho perceptivo”. Para Bosi, “é o trabalho perceptivo, que colhe as determinações do real, as quais se tornam estáveis para o nosso reconhecimento, durante algum tempo” (BOSI, 2004, p.115-117).

Esse processo de facilitação consiste na colheita de "aspectos do real já recortados e confeccionados pela cultura" e as imagens que se formam a partir desse processo acabam por exercer forte autoridade sobre nós: “O estereótipo nos é transmitido com tal força e autoridade que pode parecer um fato biológico” (BOSI, 2004, p.115-117).

Do mesmo modo, é conveniente fazermos aqui uma diferenciação entre publicidade e propaganda ${ }^{3}$. Em geral (ou no senso comum), os termos publicidade e propaganda acabam sendo utilizados indiscriminadamente como sinônimos. Entretanto, nesse trabalho, entendemos que a publicidade é um meio de tornar conhecido um produto, um serviço ou uma firma, com o objetivo de despertar na massa consumidora o desejo pela coisa anunciada ou criar prestígio ao anunciante. São ações pagas, e realizadas abertamente, sem encobrir o nome e as intenções do anunciante (BIGAL, 1999, p.20). Já para definir propaganda, utilizamos a conceituação feita por Norberto Bobbio, para quem:

A Propaganda pode ser definida como difusão deliberada e sistemática de mensagens destinadas a um determinado auditório e visando a criar uma imagem positiva ou negativa de determinados fenômenos (pessoas, movimentos, acontecimentos, instituições, etc.) e a estimular determinados comportamentos. A Propaganda é, pois, um esforço consciente e sistemático destinado a influenciar as opiniões e ações de um certo público ou de uma sociedade total. (...) Em suas acepções mais correntes, a Propaganda difere de outras formas de persuasão, enquanto realça elementos puramente emotivos, recorre a estereótipos, põe em relevo só certos aspectos da questão, revela um caráter sectário, etc (BOBBIO; MATEUCCI; PASQUINO, 1998, 1018).

\footnotetext{
${ }^{3}$ Em algumas passagens do texto, inclusive aqui na introdução, publicidade e propaganda são utilizados como sinônimo, contudo trata-se de citações de autores que em seus trabalhos não fazem distinção entre os dois termos.
} 
Nesse sentido, poderíamos discutir até que ponto a publicidade (e a cultura da mídia como um todo) traz consigo componentes de propaganda, principalmente pelo fato da propaganda valer-se "de todos os instrumentos que as condições tecnológicas põem à sua disposição em cada época” (BOBBIO; MATEUCCI; PASQUINO, 1998, 1018). No entanto, optamos por deixar essa questão para trabalhos futuros, priorizando neste a perspectiva histórica.

Por fim, é importante fazer alguns esclarecimentos. O primeiro é que apesar da pesquisa ter sido desenvolvida numa escola de comunicação, e apesar do objeto de estudo ser a publicidade, este trabalho não foi realizado por um publicitário ou por um profissional de comunicação. Na verdade, essa dissertação nasce de uma proposta de unir nossa formação em História ao campo da Comunicação Social, no intuito de investigar através dos meios de comunicação a trajetória das imagens historicamente atribuídas pelas elites aos negros no Brasil.

O segundo também diz respeito à autoria, mas num sentido mais subjetivo. Acreditamos que no transcorrer do texto deixamos transparecer que, de fato, a autoria deste trabalho é de um pesquisador negro. Contudo, como afirma Kabengele Munanga, "a emoção não impede uma análise científica”. Ocorre que essa análise é feita “de um ponto de vista que é a linguagem da vítima”4.

Já o terceiro, e aqui encerramos, é sobre capa. A idéia de colocar a “menina do Tang” para “apresentar” o trabalho ocorreu justamente porque a temos na memória como primeira referência (dos tempos de infância, inclusive) de uma pessoa negra num anúncio comercial. Outros personagens, como o “Alemão” da DPaschoal ou o “Sebastian” da C\&A também são referências - e surpreendentemente não apareceram na amostra - entretanto, a personagem interpretada pela atriz Cinthya Rachel é a única dos três que não aparece representada sob estereótipos subalternizantes.

\footnotetext{
${ }^{4}$ Entrevista concedida a Renata Nóbrega para o jornal Ìrohìn (nº 17). Disponível em: <www.irohin.org.br/imp/ template.php?edition=17 \&id=1> Acesso em: 20 ago. 2009.
} 


\section{O BRASIL IMAGINADO}

Não é que o negro não seja visto, mas sim que ele é visto como não existente. Ilka Boaventura Leite

Stuart Hall, em seu livro A Identidade Cultural na Pós-Modernidade, afirma que "as identidades nacionais não são coisas com as quais nascemos, mas são formadas e transformadas no interior da representação” (HALL, 2005, p.48). A nação seria não apenas um ente político, mas também um sistema de representação cultural, ou seja, cada pessoa, mais do que possuir o status jurídico de cidadão, participaria “da idéia de nação tal como é representada em sua cultura nacional” (HALL, 2005, p.49).

O autor argumenta que a cultura nacional é um discurso, é um modo de construir sentidos que influencia diretamente a concepção que temos de nós mesmos. Tais sentidos estariam "contidos nas estórias que são contadas sobre a nação, memórias que conectam seu presente com seu passado e imagens que dela são construídas”. Em outras palavras, para Hall, a identidade nacional seria uma "comunidade imaginada" - no sentido que Benedict Anderson dá à expressão (HALL, 2005, p.51).

Anderson entende que a condição nacional [nation-ness] é sempre uma invenção. Para o autor, a nação é um construto, é um produto cultural específico a partir do qual os membros de uma determinada comunidade (mesmo aqueles que não se conhecessem e jamais se conhecerão) criam "laços imaginários" que lhes permitem compartilhar sentimentos e objetivos comuns, daí o sentido de “imaginada” (ANDERSON, 2008).

Podemos dizer que o Brasil começou a ser "imaginado" na década de 1820, com o advento da Independência. Naquele momento, as elites nacionais careceriam de uma “autoctonia”, isto é, algo que as diferenciasse do antigo elemento colonizador.

Sabe-se que as sociedades com um passado colonial, como as americanas, tiveram de buscar novas justificativas para a sua existência histórica, ou seja, tiveram de reinventar a sua identidade, no momento em que romperam com a colonização européia (SODRÉ, 1999, p.77).

Contudo, é importante dizer que o fim do vínculo colonial não significou uma ruptura com os valores e com a cultura da metrópole. O processo de conquista e colonização da América permitiu a coexistência (no mais das vezes forçada) de elementos culturais distintos, o que resultou numa formação híbrida, sincrética, impossível de ser desfeita pelos movimentos de independência ${ }^{5}$.

\footnotetext{
${ }^{5}$ Conforme aponta Stuart Hall: “Os momentos de independência e pós-colonial (...) são necessariamente, portanto, momentos de luta cultural, de revisão e de reapropriação”. No entanto, essa “reconfiguração” não pode
} 
Apesar disso, ao falarmos em sincretismo, não estamos afirmando que os diferentes elementos culturais tenham estabelecido entre si relações não-conflitantes e igualitárias. As relações culturais, assim como toda relação social, estão sempre sujeitas a vetores de força, ainda mais quando inseridas nas relações de poder próprias do sistema colonial.

Nesse sentido, ocorreu no Brasil o que Hall chama de crioulização ou transculturação: "grupos subordinados ou marginais selecionam e inventam a partir de materiais a eles transmitidos pela cultura metropolitana dominante” (HALL, 2006, p.31).

Isso significa que no momento em que se começou a pensar o elemento nacional, ou seja, no século XIX, a construção da identidade brasileira sofreu influência capital dos ideais positivistas e das teorias raciais que reinavam no Velho Mundo.

Segundo Todorov, os filósofos iluministas foram os primeiros a desenvolver teorias sobre as raças humanas (apud SANTOS, 2002, p.45). Mas, no século XVIII, a crença na igualdade universal fazia a humanidade una, e as diferenças biológicas entre os povos não eram consideradas determinantes para o grau evolutivo do homem (SANTOS, 2002, p.47).

É no século XIX que o debate em torno das raças se amplia e ganha novos contornos. A origem comum da humanidade continuava a ser defendida pelos monogenistas, que viam nos fatores geográficos e culturais a causa das diferenças entre os povos. Mas em oposição a eles estavam os poligenistas ${ }^{6}$, que apoiados no fortalecimento das ciências biológicas, afirmavam a origem difusa do homem - correspondendo a diferença de origem às diferenças entre as raças.

Frenologia e antropometria, teorias que relacionavam a capacidade intelectual dos homens ao tamanho e formato do cérebro, foram doutrinas que surgiram profundamente ligadas à crença poligenista, assim como a antropologia criminal - para a qual a "natureza biológica do comportamento criminoso” fazia da tendência à criminalidade um elemento hereditário e passível de identificação por características somáticas (SCHWARCZ, 2008): “A versão poligenista permitia (...) o fortalecimento de uma interpretação biológica na análise dos comportamentos humanos, que passam a ser crescentemente encarados como resultado imediato de leis biológicas e naturais” (SCHWARCZ, 2008, p.48).

No entanto, a grande mudança de paradigma nos estudos racialistas do século XIX vem com a publicação de A origem das espécies (1859), de Charles Darwin. De acordo com

ser entendida como "uma volta ao lugar onde estávamos antes”, uma vez que "sempre existe algo no meio" (HALL, 2006, p.34).

6 “A partir de meados do século XX a hipótese poligenista transformava-se em alternativa plausível, em vista da crescente sofisticação das ciências biológicas e sobretudo diante da contestação ao dogma monogenista da Igreja” (SCHWARCZ, 2008, p.48). 
Lilia Schwarcz, o impacto dessa obra foi tamanho que as máximas de Darwin passaram a ser referência obrigatória, e significou uma reorientação teórica tanto para monogenistas, quanto para poligenistas (SCHWARCZ, 2008).

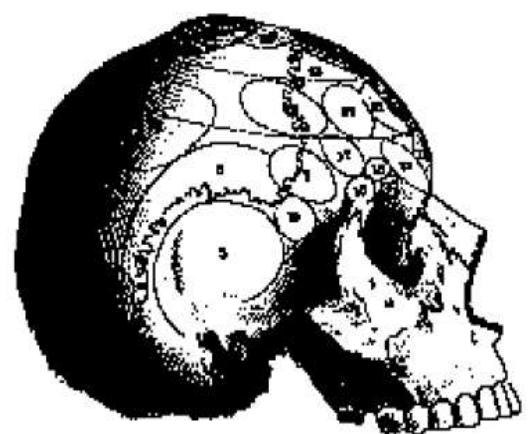

Fig. 1 - Ilustração do sistema frenológico de Gall (Human Physiology, 1841)

Apesar do teor essencialmente biológico da obra, conceitos como "seleção natural”, “evolução”, “adaptação” e "hereditariedade" foram transpostos a diversos campos das ciências sociais e aplicados (muitas vezes de maneira deturpada) ao entendimento das sociedades humanas ${ }^{7}$.

Conformava-se então a etnologia social (ou antropologia cultural), que "tinha como foco central a questão da cultura, vista, no entanto, sob uma ótica evolucionista”. Para esses antropólogos culturais, também chamados de evolucionistas sociais, o desenvolvimento das culturas deu-se de maneira sucessiva e linear, sendo cada estágio de evolução único e necessário, indo sempre do mais simples para o mais complexo (SCHWARCZ, 2008, p.57).

Schwarcz chama a atenção para o "princípio otimista” do evolucionismo social, que enxergava progresso e evolução como modelos universais e, de certa forma, obrigatórios a todos os povos, o que transformava as diferenças em contingências - "como se o conjunto da humanidade estivesse sujeito a passar pelos mesmos estágios de progresso evolutivo" (SCHWARCZ, 2008, p.58).

De outro lado estavam as escolas deterministas, entre as quais se destacou o darwinismo social ou teoria das raças. Além de afirmar a existência das raças humanas enquanto fator biológico, os darwinistas sociais acreditavam na "continuidade entre o físico e o moral”, determinando que das diferenças físicas decorreriam diferenças mentais que seriam transmitidas hereditariamente. Advém daí outra característica importante do darwinismo, que é a crença na predominância do grupo sócio-cultural ou étnico sobre o comportamento do indivíduo (SANTOS, 2002).

Para os darwinistas, raça corresponderia a um tipo final e imutável, sendo que cada uma delas teria um potencial ontológico diverso. A miscigenação representaria, por princípio, uma degeneração racial e social, vez que para esses teóricos os indivíduos mestiços seriam

\footnotetext{
7 "O darwinismo forneceu uma nova relação com a natureza e, aplicado a várias disciplinas sociais antropologia, sociologia, história, teoria política e economia - formou uma geração social-darwinista” (HOFSTADTER apud SCHWARCZ, 2008, p.55).
} 
sempre mais fracos que seus genitores, pois a eles seriam transmitidos apenas os defeitos e não as qualidades de seus ancestrais (SCHWARCZ, 2008).

Dessa forma, o progresso estaria reservado às raças puras, e a evolução não seria um fenômeno obrigatório a todos os grupos humanos. Nesse sentido, o desenvolvimento das nações estaria diretamente ligado à sua formação racial mais ou menos pura.

Independente do conhecimento "científico" de cada vertente, o fato é que ao identificar e classificar as raças humanas, evolucionistas e darwinistas estabeleceram uma hierarquização dos diferentes grupos, o que tornava certos povos superiores ou inferiores a outros.

Como a escala de valores teve uma origem marcadamente etnocêntrica, a Europa branca e “civilizada” converteu-se no paradigma para a “compreensão” do novo mundo ${ }^{8}$. Assinala Gislene Santos: “Com o apogeu da sociedade industrial e do elogio ao trabalho, os povos que não acompanhassem o grau de desenvolvimento europeu eram condenados à inferioridade” (SANTOS, 2002, p.55).

Enquanto o modelo ideal de civilização humana era a Europa, ao continente africano restou o papel de símbolo mor da barbárie e selvageria. A mitologia criada em torno da África desde os tempos antigos ${ }^{9}$ encontrava agora respaldo científico, o que formava uma base consistente para a antonimia branco civilizado versus negro primitivo. “A cultura desse povo era encarada como signo de barbárie. A vida sexual, política, social dos povos africanos foi sendo devassada e diminuída diante da vida dos europeus” (SANTOS, 2002, p.55).

No entanto, é importante ressaltar que a construção ideológica da inferioridade dos negros não foi motivada unicamente pelo estranhamento cultural. Por detrás do racismo científico estava a legitimação da conquista, dominação e usurpação dos africanos e de outros povos considerados inferiores ${ }^{10}$.

Se na Europa as teorias raciais serviram aos propósitos imperialistas de dominação da África e da Ásia, no Brasil o racismo científico foi utilizado pelas elites nacionais como

\footnotetext{
${ }^{8}$ Utilizo a expressão "novo mundo" referindo-me genericamente aos novos territórios "descobertos” pelos europeus, sem fazer correlação específica ao Novo Mundo - ou seja, à América.

9 "Para William Cohen, desde a Antigüidade greco-romana existe uma imagem distorcida acerca da África e dos africanos. Terra de figuras monstruosas segundo Heródoto, Plínio, Rabelais e tantos outros, a África era vista pela Europa como 'uma porta para o inferno'; a cultura islamita também via o negro de forma pejorativa justificando praticamente a escravidão (...)” (SANTOS, 2002, p.53).

${ }^{10}$ A superioridade do branco também serviu de caução para a penetração européia na Ásia. Para autores como Carl Carus (1849), por exemplo, a humanidade estava dividida em povos do dia (brancos), do crepúsculo oriental (hindus, malaios, mongóis), do crepúsculo ocidental (índios americanos) e da noite (africanos e australianos) (SANTOS, 2002, p.49).
} 
justificativa de um “imperialismo local” (SCHWARCZ, 2008, p.28), ou seja, a dominação de negros e mulatos para além do ordenamento social escravocrata.

Segundo Luciana Jaccoud, durante o Brasil Colônia a valorização do branco em relação ao negro não foi amparada por um pensamento racial sistemático, nem havia um projeto de nação ancorado na superioridade racial. A autora argumenta que, embora as elites compartilhassem um repertório de estereótipos negativos sobre os negros, a legitimação da escravidão vinha de outros elementos, como o imperativo econômico ou o direto de propriedade, mas nunca de teorias raciais:

antes do clímax da abolição da escravidão no Brasil, em 1888, a maior parte da sua elite pouca atenção dava ao problema da raça em si, bem como à relação entre características raciais e seu desenvolvimento futuro (SKIDMORE, 1976 apud JACCOUD, 2008, p.46-47).

Com efeito, a escravidão deixava claro qual era o papel de cada grupo dentro da hierarquia social, inibindo aspirações maiores de ascensão e mobilidade. Foi no momento em que o escravismo deixou de ser uma instituição perpétua e absoluta, que as doutrinas raciais européias passaram a ter penetração no Brasil.

A extinção do tráfico negreiro, na opinião do brasilianista George Andrews, foi o primeiro passo no caminho da abolição (ANDREWS, 1998). De fato, a lei de 1850 significou um duro golpe no sistema escravocrata, não apenas porque interrompeu o fluxo de cativos ${ }^{11}$, mas porque representou também uma vitória abolicionista, o que deu impulso ao movimento.

Além disso, a intensificação dos atos de resistência dos próprios negros (principalmente a partir de 1830) produziu um forte movimento de fugas e alforrias que diminuiu sensivelmente o número de escravos. Por volta de 1870, a escravidão atingia apenas 26\% dos 5,7 milhões de negros que habitavam terras brasileiras (em 1798, 79\% dos negros eram cativos). O censo de 1872 mostra que dentro da população total de 9,9 milhões de habitantes, existiam 4,2 milhões de negros (e mulatos) livres, número que representava 42\% da população (BACCI, 2002).

Ora, se a extinção do tráfico negreiro foi como dissemos há pouco, um duro golpe no sistema escravocrata, a Lei do Ventre Livre pode ser considerada o prenúncio do fim. Editado em 1791, o novo regulamento concedia liberdade aos filhos nascidos de escravas e, mais do que isso, alforriava os escravos pertencentes ao estado, garantia juridicamente o direito do

\footnotetext{
${ }^{11}$ No período que antecedeu a extinção do tráfico negreiro, o Brasil recebia, em média, 55 mil africanos por ano (ANDREWS, 1998).
} 
escravo comprar sua própria liberdade ${ }^{12}$, reconhecia o direito de herança entre escravos ${ }^{13} \mathrm{e}$ isentava de impostos as alforrias.

A Lei do Ventre Livre não fixou uma data específica para a Abolição. Entretanto, havia a clara percepção de que o fim do escravismo era apenas uma questão de tempo, e isso suscitava questionamentos sobre o futuro do país.

O sistema escravocrata, mesmo que nos estertores, ainda era a base sobre a qual se estruturava não só a economia, mas também as relações sociais no Brasil - ou seja, o escravismo garantia a distinção do branco em relação ao negro (escravo ou ex-escravo). Isso quer dizer que para as elites nacionais refletir sobre o futuro da nação envolvia mais do que pensar na mão-de-obra que substituiria o trabalhador escravo, envolvia pensar no que fazer com esse escravo que seria elevado ao status de cidadão. Perguntava, em 1889, o jornal a Província de São Paulo: “O que vai acontecer quando os libertos, assim educados [com liberdade] formarem paredes para impor condições de salários, de horas de trabalho de proteção para seus filhos?” (ANDREWS, 1998, p.84).

É importante lembrar que, paralelamente a isso, estavam sendo fundadas as primeiras “instituições de saber” no Brasil. As faculdades de direito de São Paulo e Recife (1827), por exemplo, surgiram logo após a Independência com o objetivo de elaborar leis próprias para o Brasil, assim como as faculdades de medicina do Rio de Janeiro e Bahia (1832) foram fundadas com o intuito de criar no país um saber médico voltado às mazelas da população ${ }^{14}$.

O Brasil independente também precisava de "elementos que garantissem se não a unidade política, ao menos uma centralidade cultural”. Assim, a cargo dos museus etnográficos (fundados a partir de 1808) e dos institutos históricos e geográficos (fundados a partir de 1838) ${ }^{15}$ ficaram as tarefas de “classificar as espécies humanas locais”, construir uma história para o país e conformar uma cultura "genuinamente nacional”. Em outras palavras, museus e institutos tinham a função de "não deixar mais ao gênio especulador dos estrangeiros a tarefa de escrever nossa história...” (SCHWARCZ, 1998).

\footnotetext{
${ }^{12}$ Apesar de ser prática comum, até então não havia legislação que garantisse tal direito.

${ }^{13} \mathrm{O}$ artigo $4^{\circ}$ da referida lei permitia ao escravo formar um pecúlio que, na ocasião de sua morte, deveria ser dividido entre o cônjuge e os herdeiros. O controle dos casamentos e dos nascimentos caberia à Igreja.

${ }^{14} \mathrm{O}$ ensino de práticas médicas teve início em 1808 com a chegada da família Real ao Brasil. Entretanto, tais estabelecimentos eram apenas “escolas cirúrgicas”, não aptas a fornecer diplomas de medicina - o que era prerrogativa da Universidade de Coimbra (SCHWARCZ, 2008).

${ }^{15}$ O Museu Nacional do Rio de Janeiro foi fundado em 1808, o Museu Paraense Emilio Goeldi em 1871 e o Museu Paulista em 1894. O Instituto Histórico e Geográfico do Rio de Janeiro foi fundado em 1838, o Instituto Arqueológico e Geográfico Pernambucano em 1862 e o Instituto Histórico e Geográfico de São Paulo em 1894 (SCHWARCZ, 2008).
} 
De um modo geral, esses estabelecimentos nasceram comprometidos com o desenvolvimento de uma ciência que respondesse às necessidades locais e com a formação de uma elite intelectual mais autônoma, capaz de pensar e intervir no futuro do país. Caberia, portanto, aos "homens de sciencia” solucionar os problemas e apontar os destinos da nação (SCHWARCZ, 2008).

Sem dúvida alguma, para as elites nacionais do século XIX, o grande problema do Brasil era o negro. Mesmo antes da penetração do racismo científico europeu, as imagens de imoral, dolente e boçal que haviam sido construídas no período colonial já eram suficientes para que muitos imputassem ao escravo (e não à escravidão) a causa do atraso brasileiro em relação à Europa.

Mais do que um problema social, o negro era uma "ameaça” ao Brasil que nascia. Para os intelectuais e líderes políticos da época, não haveria de prosperar uma nação formada majoritariamente por “elementos de cor”.

Essa crença “inabalável” na inferioridade do negro e a vontade do grupo dominante se manter no poder, explicam o pronto acolhimento que as teorias raciais tiveram no país. Além disso, para as elites brasileiras, que "sempre fantasiaram em torno da Europa como espaço simbólico superior e adequado” (SODRÉ, 1999, p.81), adotar doutrinas européias significava estar em contato direto com o progresso e a civilização.

Assim, nos diversos centros de pesquisa a discussão racial assumiu papel central, uma vez que segundo as teorias evolucionistas e social-darwinistas que aqui chegaram o "fator 'raça' era entendido como um tipo de influência vital no ‘potencial civilizatório' de uma nação” (SCHWARCZ, 2001, p.23).

No entanto, é equivocado pensar que essas doutrinas foram copiadas ou simplesmente transpostas à realidade brasileira. Na verdade, as teorias raciais européias foram introduzidas no Brasil de maneira crítica e seletiva, combinando-se darwinismo e evolucionismo de um modo que fosse possível explicar a hierarquia racial e, ao mesmo tempo, dar esperança de progresso a uma nação mestiça (SCHWARCZ, 2008).

O que interessava não era recordar o debate original, restituir a lógica primeira dessas teorias, ou o contexto de sua produção, mas, antes, adaptar o que "combinava" - da justificação de uma espécie de hierarquia natural à comprovação da inferioridade de largos setores da população - e descartar o que de alguma maneira soava estranho (...) (SCHWARCZ, 2008, p.41).

Dessa forma, do darwinismo social adotou-se a idéia da diferença e hierarquia entre as raças e a crença no mal da mestiçagem, enquanto do evolucionismo social extraiu-se o 
postulado de que as raças humanas não permanecem estagnadas, estando em constante evolução (SCHWARCZ, 2008).

Esses arranjos ficam evidentes, por exemplo, no discurso dos "homens de medicina”, para os quais a raça, ou melhor, a miscigenação, havia transformado o Brasil num país enfermo e degenerado cuja população era acometida de uma debilidade física e mental, mas que poderia ser curada através da implantação de programas eugenistas e higienistas.

Nos institutos históricos e geográficos, a combinação de teorias permitiu a seus pesquisadores justificar as hierarquias sociais e a necessidade do "branqueamento" da população, bem como criar uma História oficial para o Brasil na qual o branco fosse figura proeminente. Conforme a tese de Karl von Martius ${ }^{16}$, apresentada ao Instituto Histórico e Geográfico Brasileiro em 1844, a história do Brasil estaria atrelada ao desenvolvimento de suas raças formadoras, cabendo ao branco o papel de elemento civilizador e ao negro o espaço da detração: “Não ha dúvida que o Brasil teria tido uma evolução muito diferente sem a introdução dos míseros escravos negros” (MARTIUS apud SCHWARCZ, 2008, p.112).

O discurso racial das instituições científicas oitocentistas apontava o negro e a miscigenação como obstáculos ao progresso da nação. Se a heterogenia era um impeditivo, necessitava-se, então, compor uma nação homogênea e alinhada aos padrões de civilização. Foi dentro desse cenário que os projetos de “nação brasileira’ foram desenvolvidos. O racismo científico caucionava o caráter conservador das propostas que, de uma maneira ou de outra, “imaginavam” um Brasil no qual o negro seria “apagado”.

\section{1 - Os projetos políticos de Brasil}

Conforme dissemos há pouco, a inquietação das elites nacionais com relação ao negro teve início antes mesmo das teorias raciais chegarem ao Brasil. De fato, a preocupação com o grande contingente de “elementos de cor” já está presente na fala de políticos e intelectuais das primeiras décadas do século XIX, que viam o negro como o inimigo interno a ser domesticado.

As rebeliões de escravos, os quilombos e os ataques às fazendas faziam com que a elite branca nutrisse um grande medo da parcela negra da população. Temia-se que o escravo ao buscar a sua liberdade buscasse também exterminar seus opressores. E a revolução ocorrida em São Domingos na última década do século XVIII (processo no qual os negros

\footnotetext{
${ }^{16}$ O projeto de von Martius foi o vencedor do concurso “Como escrever a história do Brasil” realizado pelo IHGB em 1844 (SCHWARCZ, 2008).
} 
insurgiram-se contra a escravidão, tomaram o poder e declararam a independência da ilha) só fez acirrar esse temor (AZEVEDO, 2004).

Nessa época, a escravidão já era vista como o grande mal da sociedade brasileira. Por um lado, o estado de “coação, violência e miséria” no qual viviam os escravos era entendido como o fato gerador do ódio racial; por outro, o escravismo era condenado por "inundar" o país com gente "sem moral, sem leis” e “quase sem elevação sensível acima dos irracionais” (COSTA apud AZEVEDO, 2004, p.32).

Se a escravidão era um mal para o Brasil, extingui-la acarretaria outro sério problema: a falta de mão-de-obra. Assim, cabia aos pensadores do início do século XIX encontrar uma solução em que o fim o sistema escravocrata não interferisse no poder do grande proprietário.

A saída encontrada pelos emancipacionistas - nome dado aos intelectuais do período foi a abolição gradativa da escravidão, que poria fim aos conflitos raciais e daria tempo para que o Estado tomasse medidas no sentido de educar e disciplinar ex-escravos e trabalhadores livres, tornando-os úteis ao país (AZEVEDO, 2004).

Alguns autores, como José Bonifácio e Francisco Brandão Jr., propunham como medida disciplinadora a distribuição de terras aos escravos, transformando cativos em colonos que receberiam um salário e máquinas simples para a plantação. No entanto, deveriam permanecer vinculados aos seus antigos donos, visto que não seriam capazes de cuidar de si.

Outros defendiam a obrigatoriedade do trabalho para o escravo liberto, cabendo, inclusive, o uso de coação policial. Haveria liberdade para que cada um trabalhasse "segundo a sua vocação”, mas não para vagar "sem destino útil e honesto” (BARRETO apud AZEVEDO, 2004, p.40). A coerção estatal ao trabalho deveria atingir também os mendigos inclusive os inválidos ${ }^{17}$ - e os condenados às galés, que deveriam aprender um ofício útil ao invés de permanecerem nos trabalhos forçados. (AZEVEDO, 2004).

Célia Maria Azevedo ressalta que embora a população negra e mestiça "fosse considerada de baixo nível mental”, os intelectuais do período não viam empecilho na incorporação do negro à sociedade, desde que observadas certas prescrições (AZEVEDO, 2004, p.40).

Assim, era preciso coagir ex-escravos e pobres ao trabalho e manter o seu dia-a-dia sob um controle social estrito, sem descuidar de lhes abrir novas perspectivas de vida, o que significava incentivar novas perspectivas de consumo e de prazer. Estas perspectivas, porém, deveriam restringir-se ao

\footnotetext{
${ }^{17}$ Domingos Alves Branco, em sua obra Memória sobre a Abolição do Commercio da Escravatura, de 1817, afirmava, entre outras coisas, que os mendigos cegos dariam bons ferreiros e os "aleijados" bons alfaiates (AZEVEDO, 2004, p.41).
} 
âmbito do trabalho constante e disciplinado. Fora dele não haveria mais espaço para os homens livres a caminho da cidadania (AZEVEDO, p.44).

Podemos notar que os projetos emancipacionistas buscavam mais do que a educação e coação ao trabalho. O que está presente no discurso desses políticos e pensadores é uma cândida proposta de "liberdade ilusória”, através da qual a escravidão seria extinta apenas nominalmente e o espaço do negro na sociedade seria limitado ao espaço do trabalho braçal.

O movimento emancipacionista exerceu grande influência sobre o pensamento identitário brasileiro, sendo praticamente o único até meados do século XIX, quando o movimento imigrantista passou a ganhar força.

A extinção do tráfico negreiro, em 1850, coincidiu com um período de grande desenvolvimento das lavouras de café do Sudeste. Sem poder contar com o fluxo de escravos africanos, os cafeicultores da região viram-se obrigados a recorrer ao tráfico interprovincial para suprir suas necessidades de mão-de-obra.

Como o ritmo da produção cafeeira era intenso, um número acentuado de cativos foram transportados do nordeste para as lavouras paulistas, principalmente. Esse movimento demográfico - que acabou conhecido como “onda negra”, dado o volume de "elementos de cor” trazidos - fez com que a região chegasse a concentrar, em meados da década de 1880, $53 \%$ do total de escravos do Brasil ${ }^{18}$.

O crescimento da população escrava trouxe consigo o aumento das fugas, rebeliões e demais atos de resistência à escravidão, exacerbando assim o medo que o branco nutria pelo negro. Além disso, o escravo nordestino era considerado menos inteligente e mais violento que o escravo do sudeste (conseqüência do meio rústico em que viviam), o que potencializava os riscos à "segurança da raça branca” (AZEVEDO, 2004).

Frente à radicalização dos conflitos entre escravos e senhores, impunha-se aos políticos a necessidade de dar uma pronta resposta ao problema, antes que a situação fugisse ao controle institucional. Não demoraram a surgir projetos que visavam dificultar a entrada de escravos vindos de outras partes do país ${ }^{19}$. E, paralelamente a isso, aumentava cada vez mais o número de deputados que defendiam a necessidade de se promover a imigração de trabalhadores europeus, sobretudo na Assembléia Legislativa de São Paulo, província que mais absorveu escravos nesse período (AZEVEDO, 2004).

\footnotetext{
18 “Segundo o recenseamento de 1819, um quinto da população escrava residia nos estados do Norte (Maranhão, Ceará, Pará); 28\% na Bahia, Pernambuco e Alagoas; 36\% no Rio de Janeiro, Minas Gerais e São Paulo (IBGE, 1987, p. 30). A proporção dos escravos nestas três últimas províncias, às vésperas da abolição, crescera para 53\%” (BACCI, 2002, p.150).

${ }^{19}$ Esses projetos baseavam-se na cobrança de elevadas taxas e impostos para a matrícula e manutenção dos escravos, bem como a isenção de impostos para a venda dos cativos para outras províncias.
} 
Ao contrário dos emancipacionistas, que defendiam a possibilidade de elevação e integração do negro à sociedade (ainda que de maneira parcial), os assim chamados imigrantistas não acreditavam na capacidade do negro de "interiorizar sentimentos civilizados” e apontavam como única solução redentora a “importação” de trabalhadores europeus.

Claramente identificados com as doutrinas raciais européias, para os imigrantistas a abolição em si não representaria uma saída para os problemas do país, tendo em vista que os negros "imorais e degenerados” permaneceriam dispersos entre a população. Além do mais, com a desproporção entre negros e brancos haveria a tendência do mestiço se cruzar com o negro, fazendo com que o povo “enegrecido” caminhasse no sentido da degradação: “ao extinguir-se o escravo, permanecia o negro ou o mestiço com todos os seus defeitos étnicos. Por isso a emancipação por si só não poderia mudar em nada os defeitos mentais dos trabalhadores nacionais” (AZEVEDO, 2004, p.69).

A imigração, por sua vez, traria para o Brasil indivíduos de uma raça considerada superior e mais predisposta ao trabalho, que substituiria com vantagens a mão-de-obra nacional (escrava e livre). E, além disso, a presença do imigrante trazia esperanças de branqueamento (e conseqüente de progresso) da população.

Políticos como Domingos Jaguaribe Filho, médico e deputado da Assembléia paulista, argumentavam que a chegada dos imigrantes equilibraria o número de brancos e negros, facilitando assim os cruzamentos inter-raciais que conduziriam à “purificação” da sociedade brasileira: “o cruzamento do Africano muito comum com os portugueses no Brasil produz o chamado cabra ou mulato, que em cinco gerações cruzando-se por sua vez com o branco se transforma neste” (JAGUARIBE apud AZEVEDO, 2004, p.64).

O tema da purificação racial vai aparecer também na obra de Sylvio Romero, para o qual o era mestiço “a condição de vitória do branco no país”. Certo da inexistência de uma composição étnica definitiva para o país, Romero encontrava no mestiço o resultado da luta pela sobrevivência das espécies, e ao invés de condenar o processo de mestiçagem, encontrava nele a viabilidade da nação (SCHWARCZ, 2008, p.154).

A minha tese, pois, é que na vitória na luta pela vida, entre nós, pertencerá, no porvir ao branco (...). Pela seleção natural, todavia, depois de prestado o auxílio de que necessita, o tipo branco irá tomando a preponderância até mostrar-se puro e belo como no velho mundo (ROMERO apud AZEVEDO, 2004, p.60). 


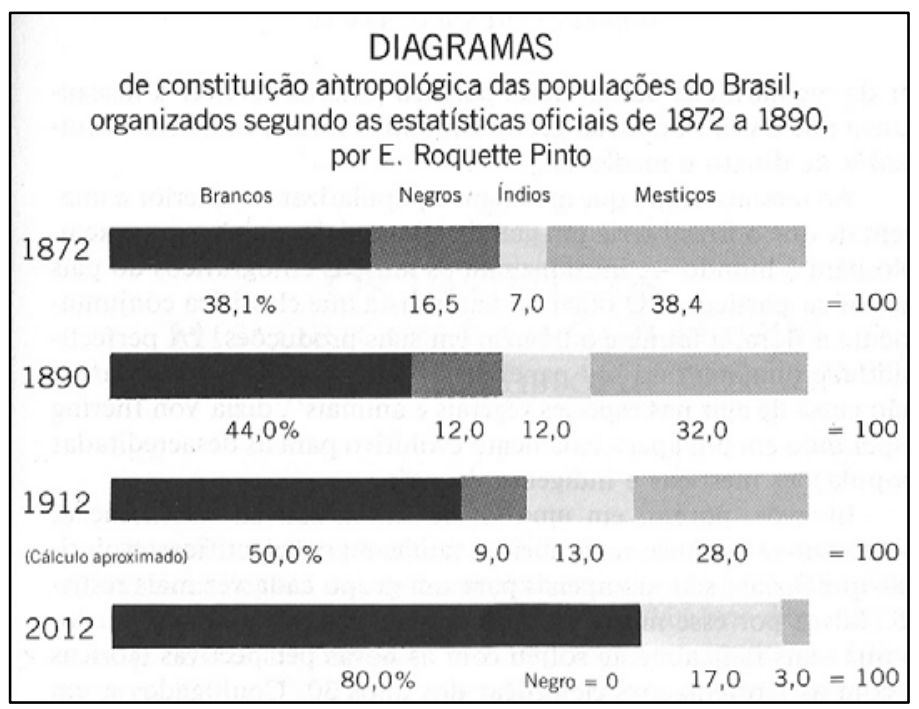

Fig. 2 - Prognósticos de branqueamento da população brasileira

Embora a formação de um mercado de trabalho livre fosse uma questão importante para os imigrantistas, o conteúdo racista de seus argumentos deixa claro que as intenções do movimento extrapolavam a questão da mão-de-obra. O que estava em jogo era a implementação de uma política eugenista que buscava a eliminação física do negro e do mestiço, garantindo assim, a prevalência da raça branca na conformação da sociedade brasileira.

Ao acompanhar passo a passo os debates parlamentares destes anos 1870 e 1880, vimos como o imigrantismo, bem como a formulação correspondente de seu ideário racista, emerge tal qual uma arma ou instrumento político manejado contra os negros, adversários temidos do cotidiano passado, presente e futuro (...) (AZEVEDO, 2004, p.136-137).

É também na década de 1850 que começa a ganhar corpo no Brasil o movimento abolicionista. A extinção do tráfico negreiro, ao mesmo tempo em que impulsionou o crescimento do imigrantismo, deu certo estímulo ao abolicionismo, já que para aqueles que lutavam contra a escravidão, a Lei Eusébio de Queiroz representou uma conquista.

Entretanto, mesmo com a "vitória” na questão antitráfico, o abolicionismo permaneceu circunscrito a uma pequena parcela da elite nacional até o final da década de 1860: “A não ser por alguns escritores anti-escravistas, não havia nada que pudesse evocar a imagem de uma comunidade de sentimento abolicionista até meados da década de 1860” (AZEVEDO, 2003, p.36).

Azevedo afirma que durante este período “os abolicionistas mais propagandeavam a abolição do que se posicionavam firmemente a respeito”. Na verdade, mesmo na década de 1880, quando o abolicionismo passa a ter vulto e caráter popular, o movimento não tinha nenhuma proposta concreta para o negro que ganharia a liberdade (AZEVEDO, 2004, p.76). 
Os abolicionistas, assim como os emancipacionistas, acreditavam na possibilidade de integração do negro à sociedade, bem como na sua regeneração através do trabalho. No entanto, ao contrário dos pensadores do início do século XIX, defendiam a imposição de um prazo final para a libertação.

Além da necessidade premente de se acabar com um regime de trabalho irracional e obsoleto, era a percepção de que o fim do escravismo estava próximo, podendo inclusive ocorrer sem a "mediação racionalizadora da política” (AZEVEDO, 2004, p.76-77), que levava os abolicionistas a enxergarem a imediata Abolição como algo imprescindível.

Manter o controle do movimento sobre o clamor das ruas era uma preocupação dos abolicionistas, para os quais uma Abolição realizada “cegamente” apenas traria desordem e colocaria o negro “degradado e viciado pela escravidão” no caminho da vagabundagem e da criminalidade.

Proclamando a si mesmos como “dirigentes máximos” do processo que levaria ao fim da escravidão, os abolicionistas enfatizavam que o negro, até mesmo pela sua condição de cativo, era incapaz de tomar por si só consciência da sua condição de explorado, tampouco seria capaz de dar sentido político aos seus atos violentos de resistência (AZEVEDO, 2004, p.188).

O movimento abolicionista insistia que a libertação dos escravos deveria acontecer dentro dos limites da legalidade, pois fora dele só restava a alternativa de uma revolução, e a intenção do movimento "não era revolucionária, mas tão-somente reformista”20. Isso significa que os abolicionistas buscavam "reordenar o social a partir das próprias condições sociais vigentes”, ou seja, a luta pela libertação dos escravos não deveria abalar “o poder do capital” (AZEVEDO, 2004, p.76).

O liberalismo que levou segmentos da elite monarquista a reivindicar a abolição da escravatura não estava comprometido com a realidade social e humana da maioria populacional, que era constituída pelos africanos e seus descendentes, e sim com a adequação das idéias nacionais ao ideário culto da Europa (SODRÉ, 1999, p.79).

Apesar das divergências entre abolicionismo e imigrantismo, é importante ressaltar que num ponto os dois movimentos tinham idéias bastante próximas: ambos buscavam minimizar a questão do ódio racial em terras brasileiras.

\footnotetext{
20 “A escravidão não há de ser suprimida no Brasil por uma guerra civil, muito menos por insurreições ou atentados locais. Não deve sê-lo, tampouco, por uma guerra civil, como o foi nos Estados Unidos. Ela poderia desaparecer, talvez, depois de uma revolução, como aconteceu na França, sendo essa revolução obra exclusiva da população livre; mas tal possibilidade não entra nos cálculos de nenhum abolicionista” (NABUCO, 1883, $\mathrm{n} / \mathrm{d})$.
} 
Para os abolicionistas, os conflitos raciais encontravam-se diretamente ligados à escravatura, e teriam fim tão logo ocorresse a abolição e o negro se tornasse um trabalhador livre. Joaquim Nabuco, por exemplo, dizia que ao contrário dos Estados Unidos no Brasil não existia “prevenção da cor”, uma vez que a “extensão ilimitada dos cruzamentos sociais entre escravos e livres" havia produzido uma população mestiça e uma sociedade sem "castas perpétuas” que aceitava o negro forro como cidadão sem restrições (NABUCO, 1883).

A escravidão, por felicidade nossa, não azedou nunca a alma do escravo contra o senhor - falando coletivamente - nem criou entre as duas raças o ódio recíproco que existe naturalmente entre opressores e oprimidos. Por esse motivo, o contato entre elas sempre foi isento de asperezas, fora da escravidão, e o homem de cor achou todas as avenidas abertas diante de si (NABUCO, 1883, n/d).

O objetivo dos abolicionistas era compor um cenário no qual a harmonia racial e social que viria com o final da escravidão (obviamente conduzido pelo movimento) permitiria uma transição pacífica do regime escravista para o sistema de trabalho livre, sem revanchismos de negros contra brancos.

Esse discurso da harmonia racial foi utilizado também pelos imigrantistas, mas com outro objetivo: propagandear nos países de imigração que no Brasil havia (e haveria) uma convivência pacífica entre as raças (AZEVEDO, 2004, p.89).

\section{2 - Abolição, imigração e branqueamento}

Depois de quase um século de discussões e medidas protelatórias, o regime escravocrata foi terminantemente abolido em maio de 1888. Se durante a escravidão os negros já eram desprezados por serem considerados inferiores, após a Abolição esse desprezo só aumentou (SANTOS, 2002, p.119). No lugar da liberdade prometida pela Lei Áurea (1888) e da igualdade enunciada pela República proclamada pouco depois (1889), o que o negro encontrou depois de tornar-se livre foi o recrudescimento das posturas racistas e das políticas imigrantistas.

Na cabeça das elites nacionais, passava a idéia de que com o fim da dominação garantida pelo escravismo “o negro, em grande quantidade no país, poderia querer alçar vôo em direção aos lugares dos brancos, poderia acreditar em sua cidadania e exigir direitos iguais, poderia crer que, de fato era livre” (SANTOS, 2002, p.130).

Na opinião de Jaccoud, o agravamento da questão racial aparece exatamente como “contrapartida possível à generalização de uma concepção universalizante de direitos do cidadão” (JACCOUD, 2008, p.48), ou seja, no momento em que a cidadania (com todos os benefícios e privilégios) foi legalmente estendida aos negros - o que, em tese, lhes permitiria 
“competir” no mundo dos brancos - a exasperação do racismo foi a maneira encontrada para mantê-los à margem da sociedade.

As teorias racialistas que orientaram os projetos de nação nos tempos do Brasil Império, apesar de ultrapassadas no continente europeu, continuaram em voga nos primeiros anos do Brasil República. Assim, ao lado do avanço econômico e da necessidade de instituições modernas, o aprimoramento racial da população persistia como fator determinante do progresso da nação.

Um exemplo de “intelectual típico” do período de transição entre Império e República foi o médico e professor da Escola de Medicina da Bahia Raimundo Nina Rodrigues. Grande nome da medicina entre o final do século XIX e as primeiras décadas do século XX, Nina Rodrigues “abraçava integralmente a idéia de uma política positiva alicerçada em diferenças naturais entre os grupos/classes que compunham a sociedade” (SANTOS, 2002, p.133).

O autor acreditava que as raças apresentam diferentes graus de evolução e inteligência, e que cada grau evolutivo compreende uma moral, de forma que valores universais - tais como os pressupostos republicanos de liberdade e igualdade - não poderiam ser utilizados como sustentáculo para uma noção única de justiça e cidadania (SANTOS, 2002, p.134).

Nesse sentido, Nina Rodrigues defendia a necessidade de uma lei que atenuasse a responsabilidade penal de negros e mestiços, já que a inferioridade atribuída a esses grupos os impedia de compartilhar da mesma noção de moral dos povos civilizados. Mas ao contrário do que possa parecer, esse tratamento diferenciado não representava uma "vantagem” ou “proteção” para a população negra.

A relativização da lei penal significava a relativização dos direitos à igualdade e à liberdade. Se o negro não deveria ser punido da mesma forma que o branco por ser inferior, também não poderia gozar de igual direito à cidadania (SANTOS, 2002, p.135).

A inferioridade natural atribuída aos "elementos de cor” e a sua suposta incapacidade de “desenvolver uma civilização” e uma “cultura elevada” eram os argumentos que justificavam o “cerceamento” da cidadania de negros e mestiços postulada pelo autor (SANTOS, 2002, 148).

Nina Rodrigues, assim como seus contemporâneos, sustentava a tese de "que o nível de civilização que o País poderia alcançar estaria na dependência do componente racial branco de sua população”. A idéia de que a estagnação de certas áreas do país estava associada à grande concentração de negros e que o progresso de outras se devia à predominância de população branca era um dos argumentos utilizados por esse pensador não 
só para dar suporte à sua tese, mas também para apoiar a imigração européia (COUCEIRO DE LIMA, 1984, p.20-21).

Aliás, é importante dizer que no início do período republicano o apoio à causa imigrantista era praticamente unânime entre intelectuais e políticos, vindo a tornar-se, inclusive, política de Estado - como bem demonstra o artigo $1^{\circ}$ do Decreto 528, de julho de 1890:

É inteiramente livre a entrada, nos portos da República, dos indivíduos válidos e aptos ao trabalho, que não se acharem sujeitos a ação criminal do seu país, excetuados os indígenas da Ásia, ou da África, que somente mediante autorização do Congresso Nacional poderão ser admitidos de acordo com as condições que forem então estabelecidas (DOMINGUES, 2003, p.37).

Mais do que proibir a entrada de "povos indesejados” e abrir o país aos europeus, os governos nacionais e estaduais buscaram incentivar a vinda de imigrantes prometendo-lhes benefícios e subsidiando as viagens. No período de 1890 a 1914, por exemplo, 63\% dos mais de 1,5 milhão de europeus que vieram para São Paulo tiveram suas passagens pagas pelo governo do estado (ANDREWS, 1998, p.98).

A imigração era tida pelas elites nacionais como prioritária para o desenvolvimento do Brasil $^{21}$, afinal traria para o país um grande contingente de indivíduos considerados de raça pura e superior, que constituiria uma mão-de-obra mais inteligente e adaptada ao trabalho livre, ao mesmo tempo em que promoveria o branqueamento "físico e moral” da população.

Contudo, a “importação” de trabalhadores europeus não foi a única iniciativa do Estado para fazer do Brasil um país branco. A eliminação física do negro não seria suficiente para negar o passado escravocrata, tampouco apagaria a "mácula” da origem mestiça. Para além de uma perspectiva futura de embranquecimento, impunha-se a necessidade de tornar “invisível” a participação do negro na História nacional.

A primeira medida nesse sentido foi tomada pelo então ministro a Fazenda Rui Barbosa, que em 1890 mandou queimar todos os papéis, livros e documentos públicos relativos à escravidão. Outra medida importante foi a não inclusão do item raça nos censos de 1900 e 1920, fato este que recebeu boa acolhida de intelectuais como João Ribeiro, que em seu artigo Brancos de toda cor, de 1923, dizia: “O nosso governo, é sabido desde há muitos anos, riscou (e fez bem em riscar) das listas de recenseamento o estigma da cor. Ninguém mais é preto nem pardo: são todos brancos” (RIBEIRO apud DOMINGUES, 2003, p.262).

\footnotetext{
${ }^{21}$ Vale ressaltar que a imigração européia foi um projeto implementado com vigor nas regiões Sul e Sudeste do Brasil. Em estados da Região Nordeste, por exemplo, a imigração teve caráter apenas residual. Podemos citar o caso do estado de Pernambuco, que em 1900 tinha apenas 11 mil imigrantes (THEODORO, 2008, p.28).
} 
O branqueamento enquanto preocupação e meta estatal fica evidenciado também na participação do Brasil no $1^{0}$ Congresso Universal das Raças, realizado em 1911. A importância atribuída ao evento pelo governo brasileiro era grande, tanto é que João Batista de Lacerda, na época diretor do Museu Nacional, participou do congresso "na condição de delegado nomeado pelo Presidente da República”, ou seja, era o representante oficial do governo brasileiro $^{22}$. E de acordo com Giralda Seyferth, Lacerda foi ao congresso justamente para "defender a tese do branqueamento da raça através da mestiçagem, como forma de resolver os conflitos e a questão racial brasileira” (SEYFERTH, 1985, p.2-3).

Em sua apresentação, Lacerda reconhecia a igualdade entre as raças, no entanto, não deixou de caracterizar a raça negra como inferior e não civilizada, sendo portadora de apenas duas qualidades: a robustez física e a força muscular. Já os mestiços, apesar de certas qualidades (quase todas herdadas do ascendente branco), não constituíam uma "raça verdadeira” por não possuírem “características fixas”. Mas dada a superioridade das características raciais do branco, a tendência da mestiçagem seria a aproximação com o tipo europeu (SEYFERTH, 1985).

A participação do Brasil no Congresso Universal das Raças, assim como a publicação do texto de Lacerda (Memória sobre os mestiços do Brasil) em francês e em inglês, deixava claro que a “ideologia do branqueamento” ${ }^{23}$ não tinha por única função confortar as angústias de uma elite agro-exportadora temerosa. Havia o interesse de propagar na Europa uma imagem civilizada e embranquecida de um país que sempre fora descrito por viajantes e exploradores do Velho Mundo como um pedaço da África na América.

Não é o objetivo, tampouco seria possível, tratar aqui de todas as facetas do processo de embranquecimento da sociedade brasileira. Nossa intenção era apenas demonstrar que "a identidade nacional brasileira emergiu para expressar a adesão a uma nação que deliberadamente rejeitava identificar-se com o todo corpo social do país, e dotou-se para tanto de um Estado para manter sob controle o inimigo interno”, ou seja, o negro (JANCSÓ; PIMENTA, 2000, p.440).

\footnotetext{
${ }^{22}$ Conforme Seyferth: "Enviar um delegado a este evento constitui por si mesmo um exemplo de que a questão racial era considerada relevante: o Brasil foi o único país latino-americano que mandou representante ao congresso' (SEYFERTH, 1985, p.2)

${ }^{23}$ Na opinião Seyferth o branqueamento se constituiu enquanto ideologia tendo em vista o seu caráter mais doutrinário do que propriamente científico (SEYFERTH, 1985, p.18).
} 


\section{IDENTIDADE E PERFORMATIZAÇÃO}

As identidades podem funcionar, ao longo de toda a sua história, como pontos de identificação e apego apenas por causa de sua capacidade para excluir, para transformar o diferente em 'exterior', em abjeto.

Stuart Hall

Analisando, ainda que brevemente, os projetos de Brasil elaborados durante o século XIX, podemos perceber no teor das propostas a presença daquilo que Sodré classifica de “funcionalidade política do racismo”, isto é, a tentativa de se garantir a unidade política da nação não só pelo ordenamento estatal, mas também pela manipulação das diferenças (SODRÉ, 1999, p.79).

Ao proporem maneiras de limitar ou apagar a participação do negro na sociedade, as elites brasileiras buscavam "reprimir a divisão do 'corpo' nacional próprio ou mesmo a simbolização do 'outro' nacional”, empenhando-se "na elaboração de uma imagem de unidade conciliatória e não conflitiva (...), ao passo que a realidade sócio-histórica é feita de contradições e diversidade” (SODRÉ, 1999, p.81).

Essa funcionalidade política do racismo apontada por Sodré vai ao encontro da idéia defendida por Hall, que vê a nação não como um simples ponto de união e identificação, mas como uma "estrutura de poder social”. A maioria das nações, afirma o autor, "consiste de culturas separadas que só foram unificadas por um longo processo de conquista violenta - isto é, pela supressão forçada da diferença cultural” (HALL, 2005, p.59); dessa forma, ao invés de pensarmos "as culturas nacionais como unificadas, deveríamos pensá-las como constituindo um dispositivo discursivo que representa a diferença como unidade ou identidade” (HALL, 2005, p.62).

Na perspectiva de Tomaz Tadeu da Silva, a representação deve ser "concebida unicamente em sua dimensão de significante, isto é, como sistema de signos, como pura marca material”. Nesse sentido, entendemos que o conceito de representação se afasta de qualquer conotação mentalista ou psicológica, sendo considerada aqui como "marca ou traço visível, exterior” (SILVA, 2006, p.90-91).

Além disso, é importante frisar que a representação não é um meio de expressão do “real”. Na verdade, conforme aponta Silva, a representação é uma “forma de atribuição de sentido”, uma vez que ela, assim como todo produto cultural, está diretamente ligada às dinâmicas sociais e relações de poder. É por meio da representação, portanto, que a identidade e a diferença adquirem sentido e se ligam aos sistemas de poder: "Quem tem o poder de representar tem o poder de definir e determinar a identidade” (SILVA, 2006, p.91). 
Ao se marcar a identidade, ou seja, ao dizer "quem somos” ou "o que somos”, estamos automaticamente marcando a diferença, isto é, dizendo "quem não somos” ou "o que não somos”. Daí, podemos depreender que “nós” e “eles” operam como “indicadores de posiçõesde-sujeito”, instrumentos que definem quem pertence e quem não pertence a determinado grupo, quem está incluído e quem está excluído, enfim, são instrumentos que demarcam fronteiras: "Ela [identidade] obedece à lógica do mais-que-um. E uma vez que, como num processo, a identificação opera por meio da différance, ela envolve um trabalho, o fechamento e a marcação de fronteiras simbólicas, a produção de efeitos de fronteira”24 (HALL, 2000, p.106).

Sendo, então, a marcação da identidade e da diferença um "ato de poder”, podemos considerar que uma identidade conseguirá se afirmar “apenas por meio da repressão daquilo que a ameaça" (LACLAU apud HALL, 2000, p.110). Assim, se o "elemento de cor" constituía, como já dito, uma ameaça à identidade eurocêntrica desejada pelas elites nacionais, foi através da representação do negro como não-civilizado (e “não-civilizável”) que o branco forjou-se civilizado: “caracterizar o negro degenerado como o ‘não cidadão’ significava também delimitar, a si próprio, como modelo ideal e último de cidadania” (SCHWARCZ, 2001, p.252).

Silva alerta para que ao entendermos identificação e diferenciação como processos discursivos, não corramos o risco de compreender a representação como elemento puramente descritivo. Conforme argumenta o autor, o conceito de representação tal como apresentado tende a fixar a identidade como descrição, como “aquilo que é”. Será o conceito de performatividade que permitirá dar ênfase à idéia de “tornar-se”, ou seja, uma concepção de identidade como construção, como transformação (SILVA, 2000, p.92).

A performatividade pode ser definida enquanto "proposições que não se limitam a descrever um estado de coisas, mas que fazem com que alguma aconteça”. São expressões que ao serem pronunciadas fazem com que algo se torne efetivo ou se realize, por exemplo: "Eu vos declaro marido e mulher”, "Declaro inaugurado este monumento" ou ainda "Você está preso” (SILVA, 2000, p.92-93).

Devemos ressaltar que, strictu sensu, "só podem ser consideradas performativas aquelas proposições cuja enunciação é absolutamente necessária para consecução do resultado que anunciam”. No entanto, expressões inicialmente descritivas podem funcionar como

\footnotetext{
${ }^{24}$ A differance citada por Hall tem a ver com o processo de formação da identidade por meio da diferença: "é apenas por meio da relação com o Outro, da relação com aquilo que não é, com precisamente aquilo que falta, com aquilo que tem sido chamado de seu exterior constitutivo que o significado 'positivo' de qualquer termo - e assim sua ‘identidade’ - pode ser construído” (HALL, 2000, p.110).
} 
proposições performativas uma vez que a repetição constante de uma idéia pode produzir o fato descrito. Seria algo próximo à profecia que se auto-realiza: um professor, ao repetir insistentemente que um determinado aluno é pouco inteligente, acaba por transformar em fato aquilo que aparentemente está apenas descrevendo. É nesse sentido que a performatividade pode ser relacionada à construção da identidade (SILVA, 2000, p.93).

Em geral, ao dizer algo sobre certas características identitárias de algum grupo cultural, achamos que estamos simplesmente descrevendo uma situação existente, um "fato" do mundo social. O que esquecemos é que aquilo que dizemos faz parte de uma rede mais ampla de atos lingüísticos que, em seu conjunto, contribui para definir ou reforçar a identidade que supostamente apenas estamos descrevendo. Assim, por exemplo, quando utilizamos uma palavra racista como "negrão" para nos referir a uma pessoa negra do sexo masculino, não estamos simplesmente fazendo uma descrição sobre a cor da pessoa. Estamos, na verdade, inserindo-nos em um sistema lingüístico mais amplo que contribui para reforçar a negatividade atribuída à identidade "negra” (SILVA, 2004, p.93).

Assim sendo, no contexto do século XIX, o aparecimento recorrente de representações pejorativas da população “de cor” nas diferentes formas de manifestação artística e cultural possibilitou a performatização da imagem subalternizante atribuída ao negro, e favoreceu sobremaneira a fixação de uma identidade negativa desse grupo no imaginário nacional.

Contudo, não devemos entender a representação (e a performatização) como fenômeno que remete a uma realidade manipulada. Como afirma Schwarcz, a representação é um "movimento dinâmico, simultaneamente condição e produto da prática social” (SCHWARCZ, 2001, p.253).

O "falar branco" manifestado nos produtos culturais do século XIX não deve ser encarado, portanto, como uma "estratégia” do grupo dominante, tampouco resultado de uma realidade intencionalmente forjada "enquanto expediente exterior de exploração”. O discurso racial oitocentista seria, na realidade, um "arsenal cultural” que se produziu dentro do processo de constituição da nação (SCHWARCZ, 2001, p.252).

Nesse sentido, Anderson destaca que duas “formas de criação imaginária”, o romance e o jornal, foram particularmente importantes na gênese da nação enquanto construto (enquanto comunidade imaginada) justamente porque "proporcionaram meios técnicos para 're-presentar' o tipo de comunidade imaginada correspondente à nação” (ANDERSON, 2008, p.55).

Anderson considera que a estrutura do romance literário é um mecanismo que permite descrever uma sociedade de maneira sólida e estável, na qual todas as ações podem acontecer ao mesmo tempo, mas sendo realizadas por agentes que não precisam se conhecer, mas que carregam alguma ligação entre si (ANDERSON, 2008, p.56). 
Além disso, a “comunidade imaginada” também está presente no fato dos autores não terem “a menor idéia das identidades individuais de seus leitores” (ANDERSON, 2008, p.58), e mesmo assim escreverem com intimidade, como se os espaços, fatos e sentimentos apresentados fossem plenamente compartilhados por todos.

Para o autor, o livro foi a primeira mercadoria industrial com produção em série ao estilo moderno ${ }^{25}$, e a sua reprodução em massa teria favorecido a difusão do romance literário. O jornal, por sua vez, é visto como uma “forma extrema” do livro, "um livro vendido em escala colossal, mas de popularidade efêmera” (ANDERSON, 2008, p.66-67).

Cada leitor, assevera Anderson, é consciente de que um número incontável de pessoas “cuja existência lhe é indubitável, mas cuja identidade é totalmente desconhecida” está, simultaneamente, lendo o mesmo jornal. E é ao ver, ou imaginar, réplicas idênticas sendo consumidas que o leitor "reassegura-se continuamente das raízes visíveis do mundo imaginado na vida cotidiana” (ANDERSON, 2008, p.68).

Desse modo, frente ao que foi apresentado até aqui, acreditamos ser conveniente analisar de quais maneiras os africanos e seus descendentes foram caracterizados pelo homem branco na literatura e na imprensa brasileira do século XIX.

\section{1 - O negro na literatura oitocentista}

De acordo com Domício Proença Filho, a presença do negro na literatura brasileira não escapou ao tratamento marginalizador que marcou, desde as instâncias fundadoras, a etnia no processo de construção da nossa sociedade (PROENÇA, 2004, p.161). Em artigo intitulado A trajetória do negro na literatura brasileira, o autor ressalta que no discurso literário nacional, o reconhecimento do negro enquanto personagem, ou a adoção de "aspectos ligados às vivências do negro" como tema, sempre envolveu "procedimentos que, com poucas exceções, indiciam ideologias, atitudes e estereótipos da estética branca dominante” (PROENÇA, 2004, p.161).

As afirmações de Proença corroboram um conjunto de pesquisas anteriores que desde a década de 1950 vêm trabalhando essa questão. Um dos primeiros autores a estudar a participação do negro na literatura nacional foi Roger Bastide, que em 1953, publicou Estereótipos de Negros Através da Literatura Brasileira.

Segundo Bastide os estereótipos raciais estiveram presentes na literatura brasileira desde suas origens, mas somente no século XIX, com a proximidade cada vez maior da

\footnotetext{
25 “Uma libra de açúcar é apenas uma quantidade, um volume prático, e não um objeto em si. Já o livro (...) é um objeto distinto, contido em si mesmo, reproduzido fielmente em larga escala” (ANDERSON, 2008, p.67).
} 
Abolição, é que os estereótipos do negro passaram a ser baseados nos tipos sociais, em oposição a uma literatura colonial que percebia (e repelia) o negro enquanto bloco (BASTIDE, 1972).

Nesse texto, Bastide analisa obras do Romantismo e do Naturalismo brasileiro, e aponta uma série de estereótipos negativos sob os quais o negro aparece representado na literatura nacional do século XIX:

o negro bom (estereótipo da submissão); o negro ruim (estereótipo da crueldade nativa e da sexualidade sem freios); o africano (estereótipo da feiúra física, da brutalidade rude e da feitiçaria ou da superstição); o creoulo (estereótipo da astúcia, da habilidade e do servilismo enganador); o mulato livre (estereótipo da vaidade pretenciosa [sic] e ridícula); a creoula ou a mulata (estereótipo da volúpia)... (BASTIDE, 1972, p.22).

Outro importante trabalho relacionado a este tema é o livro Raça \& cor na literatura brasileira, de David Brookshaw. Nessa obra, o autor afirma que a figura do negro na literatura brasileira anterior a 1850 praticamente não existiu, e identifica como principal razão o fato "de que o escritor brasileiro não considerava o escravo de modo nenhum um ser humano” (BROOKSHAW, 1983, p.26).

Brookshaw coloca que o negro aparece na literatura nacional exatamente para contrastar com o índio, que simbolizava o espírito da liberdade individual e do nacionalismo brasileiro (BROOKSHAW, 1983, p.27).

Enquanto o ameríndio, em obras como Os Timbiras (inacabado), de Gonçalves Dias e O Guarani (1857), de José de Alencar, representava “a força e a exuberância da natureza brasileira e da poética simplicidade do ‘selvagem nobre’ de Rousseau”, o negro encarnava “a realidade da raça colonizada”: "Se o índio por natureza era corajoso e profundamente orgulhoso de sua independência, o negro era de índole escrava humilde e resignada” (BROOKSHAW, 1983, p.27). Podemos ver isso claramente nesse trecho do poema Tabira de Gonçalves Dias:

Vivem homens de pel'cor da noite

Neste solo, que a vida embeleza;

Podem servos debaixo do açoite

Nénias tristes da pátria cantar.

Mas o índio que a vida só preza

Por amor dos combates e festas

Dos triunfos sangrentos e sestas

Resguardadas do sol no palmar. 
Para o autor é a extinção do tráfico negreiro que força os escritores brasileiros a voltarem sua atenção aos escravos, uma vez que o prolongamento da escravidão dependeria consideravelmente da maneira como os negros eram tratados. Seria esse então o motivo pelo qual a literatura de 1850 em diante passou a demonstrar certa preocupação em relação aos escravos (BROOKSHAW, 1983, p.28).

No entanto, como Brookshaw ressalva, essa preocupação não advinha de um pressuposto humanitário dos escritores, mas sim da premissa "que a escravidão era ruim para os donos de escravos porque os colocava em contato com degenerados morais”. Assim, essa literatura que Brookshaw classificou como abolicionista enxergava a Abolição como uma necessidade e não como algo propriamente desejável, e pretendia, na verdade, "incutir medo" nos senhores brancos (BROOKSHAW, 1983, p.32).

É justamente por isso que o autor afirma não admirar que expansão da literatura abolicionista, que ocorreu com mais força após a Lei do Ventre Livre, tenha se dado num “tom eminentemente racista” (BROOKSHAW, 1983, p.32).

Quanto ao negro, não há evidência de que os escritores abolicionistas o considerassem um ser humano por direito nato. Eles fizeram uso de estereótipos facilmente reconhecíveis, traindo assim seu preconceito fundamental, e mais tarde ajudando a inculcar esse mesmo preconceito em seus leitores (BROOKSHAW, 1983, p.41).

A partir de suas análises, Brookshaw identifica esses "estereótipos facilmente reconhecíveis” e os divide, basicamente, em cinco categorias: o escravo fiel, o escravo nobre, o escravo vítima, o escravo imoral e o escravo demônio.

Essas categorias são também utilizadas por Proença que, com algumas divergências, toma assumidamente a obra de Brookshaw como ponto de partida para seu estudo. O primeiro estereótipo apontado por Proença é o escravo nobre, "que vence por força de seu branqueamento, embora a custo de muito sacrifício e humilhação”. (PROENÇA, 2004, p.162). A escrava Isaura, de Bernardo Guimarães (1872) e o personagem Raimundo de $O$ mulato, escrito por Aluísio de Azevedo (1881), são apontados pelo autor como exemplos dessa "nobreza” que está diretamente ligada à aceitação da submissão. Isso fica claro nesse trecho de A escrava Isaura:

- Não gosto que a cantes, não, Isaura. Hão de pensar que és maltratada, que és uma escrava infeliz, vítima de senhores bárbaros e cruéis. Entretanto passas aqui uma vida, que faria inveja a muita gente livre. (...)

- Mas senhora, apesar de tudo isso que sou eu mais do que uma simples escrava? Essa educação, que me deram, e essa beleza, que tanto me gabam, de que me servem?... São trastes de luxo colocados na senzala do africano. A senzala nem por isso deixa de ser o que é: uma senzala. 
- Queixas-te de tua sorte, Isaura?

- Eu não, senhora: apesar de todos esses dotes e vantagens, que me atribuem, sei conhecer o meu lugar (PROENÇA, 2004, p.162).

Outro estereótipo é o negro vítima. Associado principalmente à figura do escravo, o negro acaba por transformar-se "em objeto de idealização, pretexto para a exaltação da liberdade e defesa da causa abolicionista” (PROENÇA, 2004, p.163). Esse estereótipo está presente em textos como O navio negreiro, de Castro Alves (1868), que destaca a desumanidade do tráfico de escravos:

\author{
Era um sonho dantesco... o tombadilho \\ Que das luzernas avermelha o brilho. \\ Em sangue a se banhar. \\ Tinir de ferros... estalar de açoite... \\ Legiões de homens negros como a noite, \\ Horrendos a dançar... \\ Negras mulheres, suspendendo às tetas \\ Magras crianças, cujas bocas pretas \\ Rega o sangue das mães: \\ Outras moças, mas nuas e espantadas, \\ No turbilhão de espectros arrastadas, \\ Em ânsia e mágoa vãs! (CAMARGO, 1993, p.135).
}

Como bem destaca Proença, esses textos, apesar da filiação à causa abolicionista, não fogem à tônica do seu tempo, ou seja, não dão voz e não buscam a "especificidade cultural e psicológica do negro” (MERQUIOR apud PROENÇA, 2004, p.164). O que se pretendia era, num momento em que o negro é visto como coisa, afirmar "em altos brados” a sua condição humana e contribuir para a instalação de uma “culpa moral” nas classes dominantes (PROENÇA, 2004, p.164).

O negro infantilizado, serviçal e subalterno também é apontado como um estereótipo comum na literatura brasileira, a exemplo da personagem Bertoleza de O cortiço (1890), de Aluísio Azevedo:

Bertoleza é que continuava na cepa torta, sempre a mesma crioula suja, sempre atrapalhada de serviço, sem domingo nem dia santo: essa, em nada, em nada absolutamente, participava das novas regalias do amigo: pelo contrário, à medida que ele galgava posição social, a desgraçada fazia-se mais e mais escrava e rasteira. (PROENÇA, 2004, p.165).

Em oposição a esse, estão o escravo demônio, "tornado fera por força da própria escravidão" e o negro pervertido, promíscuo, objeto sexual: "O negro ou o mestiço de negro erotizado, sensualíssimo, objeto sexual, é uma presença que vem desde a Rita Baiana, do $O$ cortiço (1890), e mesmo do mulato Firmo, do mesmo romance (...)” (PROENÇA, 2004, p.165-166). 
Foi um forrobodó valente. A Rita Baiana essa noite estava de veia para a coisa; estava inspirada! divina! Nunca dançara com tanta graça e tamanha lubricidade!

Também cantou. E cada verso que vinha da sua boca de mulata era um arrulhar choroso de pomba no cio. E o Firmo, bêbedo de volúpia, enroscavase todo ao violão; e o violão e ele gemiam com o mesmo gosto, grunhindo, ganindo, miando, com todas as vozes de bichos sensuais, num desespero de luxúria que penetrava até ao tutano com línguas finíssimas de cobra (AZEVEDO, 1890, n/d).

A propósito, o estereótipo da mulata na literatura nacional esteve sempre ligado ao exotismo e à sensualidade “típica” das mulheres “de cor”. Caracterizada por seus atributos estéticos e por seus "modos fogosos", a mulata era tida como "excelente elemento catártico para o desencadeamento de paixões irreprimíveis” (QUEIROZ, 1975, p.33), o que fazia dela o “agente de precipitação" da trama, ou seja, o elemento "provocador do remate da narrativa" (QUEIROZ, 1975, p.16).

Como tipo literário, é direta e intensamente associada às suas características étnicas, tomadas como indicação de seu caráter, que a mulata se define. Em sua descrição se assinala, com freqüência, o colorido da pele, (...) o bem torneado de braços e pernas, mãos e pés pequenos, a cintura fina, o busto insinuante e bem moldado, a boca sensual, de dentes sadios, iluminados por sorrisos fáceis, sonoros e comunicativos; (...) eis o tipo de mulata mais comumente registrado literariamente (QUEIROZ, 1975, p.30).

No entanto, essa exaltação da beleza da mulata não correspondia propriamente a uma valorização da mulher “de cor”, já que, como afirma Bastide, a "imagem da linda mulata (...) é menos uma glorificação da côr negra do que uma glorificação da côr branca: a mulata era escolhida porque se aproximava mais da européia do que da africana...” (BASTIDE, 1972, p.11-12).

É importante dizer que essas representações do negro manifestavam-se também nas produções teatrais do período. Assim como a literatura, o teatro brasileiro só veio a fazer do negro personagem após a extinção do tráfico negreiro, em 1850, e dispensou a ele tratamento igualmente pejorativo.

A personagem negra, pois, foi usada pela dramaturgia brasileira do século passado de duas formas bem definidas: como elemento característico da sociedade da época (comédias), ou como personagem representativa, às vezes simbólica, de um problema social (o cativeiro) que ia se tornando dia a dia mais cruciante (dramas) (MENDES, 1982, p.198).

Enfim, a despeito de certa diferença nos estereótipos e formas de representação, o que podemos perceber é que na produção ficcional oitocentista o negro era descartado como ser humano e visto como ser “exótico-bestial” (MOURA, 1988, p.26), restando ausente da literatura e do teatro “o negro como ser, como homem igual ao branco” (MOURA, 1988, p.28). 


\section{2 - O negro e a imprensa do século $\mathrm{XIX}^{26}$}

Único veículo eficiente de comunicação de massa no século XIX (SCHWARCZ, 2001, p.57), a imprensa brasileira, apesar de incipiente, também desempenhou papel importante na construção de uma imagem pejorativa e subalternizada do negro.

Como aponta Schwarcz, nas diversas seções que compunham os periódicos da época, os indivíduos “de cor” apareciam envolvidos em vários e diferentes espaços, que iam "como que definindo e redefinindo a figura negra e escrava”. A imagem do negro era constantemente associada às idéias de violência, dependência, barbarismo e exotismo, na mais das vezes amparadas pelas teorias raciais oriundas da Europa (SCHWARCZ, 2001, p.99).

As primeiras partes dos jornais - os editoriais e seções “scientíficas” - eram os locais onde mais referências se faziam ao discurso científico europeu. Através de uma terminologia acessível e que permitia uma fácil popularização de certos conceitos, enaltecia-se o positivismo, as ciências naturais e, em especial, a teoria da evolução, que reduzia "as mudanças na sociedade humana a regras de evolução biológica, adaptadas às conjunturas política e ideológica daquele momento” (SCHWARCZ, 2001, p.102).

Ao lado das teorias darwinistas e evolucionistas, aparecia de forma constante o conceito de civilização, empregado quase sempre na intenção de reputar algum fato como positivo, ou atacar algum acontecimento considerado negativo, a exemplo dessa nota veiculada no jornal A Província de São Paulo de 8 de maio de 1879: “É vergonhoso e tristíssimo e altamente comprometedor aos nossos créditos de povos civilizados o que se deu ontem as 8 1/2 h” (SCHWARCZ, 2001, p.109).

O contraponto ao ideal de civilização era, via de regra, o continente africano, interpretado “como berço do barbarismo, da violência, da superstição e da magia”. A África, em muitos momentos, era tomada, inclusive, como sinônimo de tudo que indicasse inferioridade ou decadência (SCHWARCZ, 2001, p.117), como podemos ver nessas notícias de A província de São Paulo, datadas de 14 de dezembro de 1879 e 24 de setembro de 1881, respectivamente:

Escândalo - Existe nesta cidade quasi moribundo Ignácio Bicudo de Godoy que, por espaço de 30 annos mais ou menos offereceu o triste espetáculo de sua ruína... Em que país estamos? Na Costa da África.

Barbárie policial - Ainda que se tratasse de um grande criminoso, não há explicação possível para esbordoar-se assim tão africanamente a quem quer que seja... tais scenas sem dúvida deshonram a sociedade e a civilização.

\footnotetext{
${ }^{26}$ Nesse tópico todas as citações a jornais foram extraídas de: SCWARCZ, Lilia Moritz. Retrato em Branco e Negro: jornais, escravos e cidadania em São Paulo ao final do século XIX. Cia das Letras, São Paulo, 2001.
} 
Se o discurso dos editoriais era um tanto distanciado do cotidiano mais imediato das cidades, as seções de notícias traziam assuntos mais acessíveis ao público leitor. E nessas partes, que noticiavam assuntos diversos e procedentes de várias partes do país, a presença do negro era constante.

Das notícias sobre o negro analisadas por Schwarcz, a grande maioria ligava-se, de alguma forma, a ações violentas ${ }^{27}$. As formas de tais atos eram diversas, indo da "fúria repentina” até os crimes premeditados (SCHWARCZ, 2001, p.120).

Rapto extraordinário - A moça era filha de um abastado fazendeiro em Minas. Costumava ir todos os dias lavar o rosto em uma bica próxima da casa da fazenda. O negro, que já formara o seu plano, (...) amordaçou-a e carregou-a para matta próxima... Finalmente encontraram a moça, sendo que o preto saltou armado como uma verdadeira fera. Foi acertado cahiu mas arremeteu-se para matar a moça. Os outros conseguiram agarrar e subjugar aquella fera com face humana (A Província de São Paulo, 22/09/1887).

A violência do negro tinha diferentes alvos (como feitores e capitães-do-mato), podendo ocorrer, inclusive, entre negros. No entanto, quando a agressão era contra o branco, as “maiores vítimas” eram sem dúvida os senhores (e senhoras) de escravos.

Mais um assassinato acaba de dar-se na Fazenda Morro Grande pertencente ao nosso amigo o Sr. Segisberto Motta Paes (...). Os escravos a foiçada e de traição cuelmente assassinaram-no e vieram a cidade apresentar-se na cadeia o seu nefasto crime com o maior cynismo e no meio de risadas contaram o facto em seus pormenores (Correio Paulistano, 12/07/1879).

Facto horroroso - D. Gertrudes era mãe de numerosa família, possuía só 8 ou 10 escravos de serviços. Carlo (o filho) era moço de 20 e poucos annos casado há três ou quatro annos. Não eram maus senhores. Os principais autores do crime, dois escravos irmão foram amamentados pela victima que os estimava desveladamente (A Província de São Paulo, 11/06/1878).

Nas notícias acima reproduzidas notamos características que eram tônicas nos jornais da época: os atos de violência eram cometidos quase sempre por escravos "sem nome" contra senhores conhecidos, admirados e bondosos que os tratavam com benevolência. Os agentes agressores eram negativamente adjetivados (feras, cínicos, traidores) e a razão das agressões muitas vezes não é noticiada.

Isso contribuía para que a violência do negro deixasse de ser encarada como fato isolado e passasse a ser considerada um atributo da raça. Como afirma Schwarcz "a associação entre o elemento de cor e a noção de violência era tão imediata nas notícias que expressões como 'páginas negras', 'negro crime' eram então comumente utilizadas para caracterizar atos violentos” (SCHWARCZ, 2001, p.122).

\footnotetext{
${ }^{27}$ De um total de 787 notícias sobre negros catalogadas do jornal A Província de São Paulo, 226 referiam-se à violência. Já no Correio Paulistano, esses números são 649 e 237, respectivamente (SCHWARCZ, 2001, p.257).
} 
No outro lado da moeda estava o negro dependente, fiel e "amigo dos brancos”. Visto como "naturalmente" incapaz de sobreviver sem a tutela de seu senhor, muitas notícias buscavam mostrar que o negro liberto vivia em situação mais deplorável que o escravo.

O delegado, a pedido de fazendeiros, no dia 12 mandou busca na Olaria de Felisberto de tal onde se dizia haver escravos acoutados (...) Foram todos apreendidos (...) No interrogatório afirmaram que o trabalho era pesado e só recebiam o sustento e alguma roupa, sendo que um deles chegou a dizer que a vida na casa de seu senhor era preferível à que alli onde estava, desamparado, que estava arrependido de ter dado ouvidos a pessoas que o desencaminharam (...) Por todos os modos exploram-se a natural ignorância (Correio Paulistano, 11/1886).

Associada tanto ao negro violento, quanto ao negro dependente, estava a imagem do negro degenerado. Principalmente a partir da década de 1880, proliferava nos jornais a imagem do indivíduo negro como imoral, cheio de vícios, bêbados e dados a práticas bárbaras como a capoeira e a feitiçaria.

Aliás, como descreve Schwarcz, as práticas bárbaras eram outra "grande marca" atribuída aos negros. O bruxeiro era representado como indivíduo tolo e supersticioso, ou como charlatão, enganador e criminoso, e suas práticas de "feitiçaria" eram vistas com temeridade e ironia (SCWARCZ, 2001).

Feiticeiro. Bragança - Para o lado das pedras mora um preto velho tido e havido como tal. Sua casa é freqüentemente procurada por forros ou cativos que vão consultar ou receber lições de bruxaria (...) Admira que nessa ephoca haja quem ainda acredite em feitiçarias que quando muito podem ser sob certas fórmulas e aparatos a aprendizagem de saber conhecer drogas nocivas ou plantas venenosas com o fim de fazer mal à vida dos senhores ou desaffectos (A Província de São Paulo, 04/03/1879).

Feiticeiro - Andou por aqui um sujeito preto ainda moço (...) Será doutor? A esta pergunta respondiam uns que sim e outros que não. É doutor effectivamente formado por aclamação dos similunios pascacios. Doutor de lesma e caramujo dos parvos. Chama-se Luiz de tal e tem famma de excellente feiticeiro (A Província de São Paulo, 16/09/1884).

Entre outras imagens atribuídas aos negros pelos jornais, Schwarcz identifica o negro insubordinado, ligado às constantes fugas de escravos, o negro vagabundo dado à vadiagem e ao alcoolismo, e o negro suicida, que cumpria, basicamente, dois papéis: ora reafirmava o caráter dependente do negro, afirmando sua incompatibilidade com a “civilização”, ora reforçava seu caráter degenerado e cheio de vícios (SCHWARCZ, 2001): “Cadáver - Junto ao Rio Tietê, já desfigurado, foi encontrado o escravo de nome Anastácio, a quem atribui-se a desarranjos mentaes o fato de ter elle se atirado ao rio" (Correio Paulistano, 17/02/1877). 
É relevante frisar que no transcorrer do século XIX essas representações negativas do negro sofreram alterações no que tange à prevalência ${ }^{28}$, contudo, nunca deixaram de estar presente nos periódicos da época. E nos raros momentos em que a notícia se referia ao negro (africano ou brasileiro) de maneira positiva, “a exceção só servia para confirmar a regra, já que esses indivíduos eram descritos como 'objetos exóticos e pitorescos' que em nada contribuíam para alterar a imagem negativamente predominante” (SCHWARCZ, 2001, p.170).

Africano ilustre - Salve o primeiro homem preto que soube ao tocar em nosso paiz, gravar em nosso espírito admiração e respeito pela sua pessoa. Esse homem ilustre, natural das regiões africanas acompanha o progresso evolutivo das nações mais adiantadas e resolvemos oferecer-lhe esse quadro como prova de apreço (Correio Paulistano, 11/05/1886).

Um casamento democrático - O cidadão Jorge, aquelle bom pardo que já foi captivo do Sr. Desembargador Galvão, mas que não obstante isso gozou sempre de bons créditos, que ficou conhecido pelo apelido de rei dos pardos, é hoje nada menos que chefe de família. Casou-se tendo por testemunhas dois cavalheiros distinctos de nossa sociedade e pode-se dizer sem medo de errar que recebeu com a maior amabilidade os parabéns das pessoas que a seu convite foram até a sua casa tomar uma chávena de chá (Correio Paulistano, 27/06/1876).

As notícias, afirma Schwarcz, pareciam cumprir uma “função exemplar", transformando situações particulares em dramas públicos amplamente divulgados. Assim, nessas seções, a veiculação cotidiana de representações sobre os negros convertia imagens diversas em consensos sociais (SCHWARCZ, 2001, p. 133).

E como essas imagens estavam quase sempre ligadas à barbárie e ao servilismo, os jornais acabavam por mostrar como verdade, ou ao menos como pressuposto, que os negros (salvo raríssimas exceções) encontravam-se distantes “dos padrões de comportamento da jovem República” (SCHWARCZ, 2001, p.225).

\section{3 - Os anúncios de escravos ${ }^{29}$}

Outra fonte importante para o estudo da imagem do negro no século XIX são os anúncios de jornal. Principal fonte de renda dos periódicos da época, os anúncios eram abundantes, chegando a dividir, e até mesmo a superar, o espaço destinado aos editoriais e às notícias (SCHWARCZ, 2001, p.133).

\footnotetext{
${ }^{28}$ Como aponta Schwarcz, no período de 1875 a 1885, predominam as imagens do negro violento e do negro fiel e amigo dos brancos; já de 1885 a 1888, predominam o negro fugitivo (insubordinado) e o negro vítima da escravidão; no período pós abolição, 1888 a 1900, a imagem que predomina é a do negro degenerado e cheio de vícios (SCHWARCZ, 2001).

${ }^{29}$ Nesse tópico todas as citações a jornais foram extraídas de: SCWARCZ, Lilia Moritz. Retrato em Branco e Negro: jornais, escravos e cidadania em São Paulo ao final do século XIX. Cia das Letras, São Paulo, 2001.
} 
Mas a relevância dos anúncios não estaria propriamente na quantidade de material, e sim no "contraste entre a linguagem utilizada no jornal como um todo e a dos anúncios". Conforme nos diz Schwarcz, nos anúncios “aparece um discurso menos rígido, onde podemos observar mais facilmente ainda expressões e costumes da época” (SCHWARCZ, 2001, p.133).

Gilberto Freyre, um dos primeiros a se debruçar sobre este tipo de material ${ }^{30}$, afirmava que o os anúncios transbordavam "verdadeiros 'à-vontades' de linguagem oral, popular e até folclórica”, uma vez que escritos por brasileiros “inacadêmicos” que buscavam redigir eles próprios, “com toda a espontaneidade”, anúncios relativos a objetos, sujeitos e escravos (FREYRE, 1985, p.XV).

Aliás, é bom que se diga que boa parte dos anúncios de jornal, referiam-se a escravos. Cada número de um periódico, destaca Schwarcz, trazia em média vinte anúncios (de diferentes produtos e tamanhos), dos quais aproximadamente seis tratavam de alguma transação econômica envolvendo cativos: compra, venda, aluguel, leilão, fugas, depósitos, entre outras (SCHWARCZ, 2001, p.134).

Estes anúncios, em geral, apareciam de forma destacada, não só pelas letras grandes e títulos em negrito, mas também pela posição central que ocupavam nas páginas do periódico (SCHWARCZ, 2001, p.134). Além disso, era comum que os anúncios referentes à fuga de escravos viessem ilustrados pela figura de um negro com uma trouxa, em alusão à fuga da casa de seu senhor.

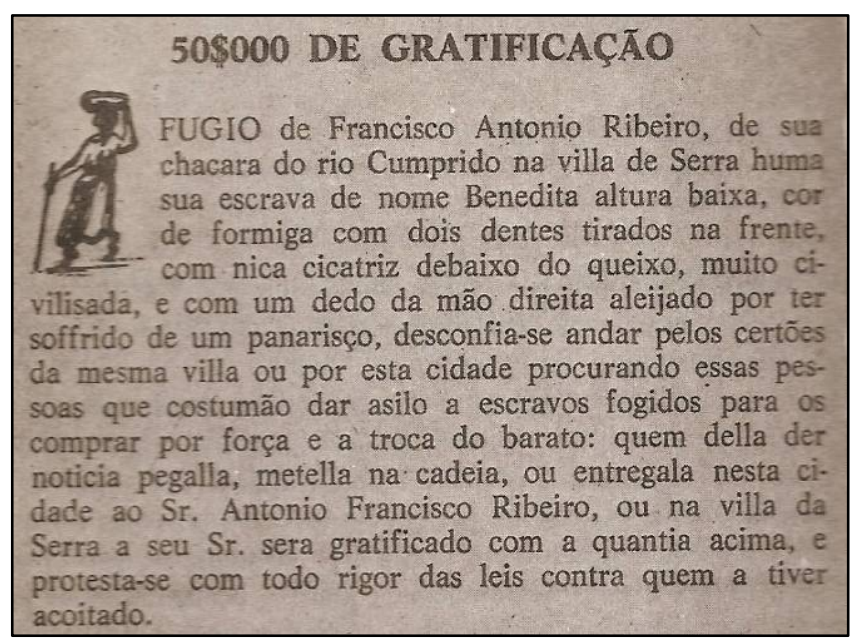

Fig. 3 - Anúncio de escravo em jornal brasileiro do século XIX

\footnotetext{
${ }^{30}$ Freyre, que chegou a batizar esses estudos de Anunciologia ("uma quase ciência nova”), acreditava que os anúncios constituiriam documentação valiosa para estudo "histórico-social, sociológico e antropológico, dos antecedentes do brasileiro como o tipo já inconfundivelmente nacional que é hoje” (FREYRE, 1985, p.XXXVI).
} 
No que tange ao conteúdo, os anúncios de fugas de escravos obedeciam, com certa variação, a uma mesma ordem interna. O nome do anunciante aparecia no início, ou destacado ao final do anúncio; depois vinham informações como o nome do cativo, as circunstâncias de sua fuga e suas características “físicas e morais” (SCHWARCZ, 2001, p.146-147).

400:000 RS - Gratifica-se com a quantia acima a quem prender e entregar ao abaixo asignado, em Campinas, os escravos seguintes. Ladisláu, 24 annos, preto, estatura regular, bons dentes, prosa e muito risonho, apto para o serviço de roça e cosinha (...). Marcos, 27 annos, estatura regular, corpo reforçado, côr parda bem clara, cabellos pretos, finos annellados. Passa por domador de animaes, sabe ler e escrever, entende de cosinha, de pedreiro e carpinteiro (...). João J. de Araujo Vianna (Província de São Paulo, 22/05/1878).

Da chácara do Pacaembu de cima fugiu no dia 31 de março Dionísio, edade 45 annos mais ou menos... [segue descrição]... Tem o hábito inveterado de fugir e de roubos repetidos, e de modos humildes e insinuantes, astuto e velhaco como poucos - São Paulo (Província de São Paulo, 04/04/1882).

É interessante notar que em anúncios como os citados acima, ao lado de dados objetivos que serviriam para facilitar a identificação e captura do escravo fugido (idade, cor, altura), podemos encontrar informações que aparentemente em nada auxiliariam uma possível apreensão: "modos humildes”, "prosa e risonho”, “inclinação a funções”, “dado a folias e sambas”31.

Tais descrições, diz Schwarcz, evidenciavam a forma como o senhor branco representava o escravo evadido, parecendo não estarem diretamente relacionadas ao objetivo primeiro do anúncio, e sim a uma “dimensão simbólica” do escravo (SCHWARCZ, 2001, p.148). É nesse sentido que a autora vai afirmar que o anúncio, para além de sua função exclusivamente pragmática, acabou por tornar-se “depositário de uma série de representações sociais” (SCHWARCZ, 2001, p.147).

Essas imagens do negro presentes nos anúncios de fuga indicavam que o “objeto procurado” não era um só, ou seja, que os senhores conformavam diferentes representações do escravo, dependendo não só da idade e do sexo, mas também do local onde viviam (e se evadiam) esses escravos.

Os escravos urbanos, por exemplo, eram geralmente descritos como indivíduos saudáveis, de boa aparência e muitas vezes “eruditos”, e o anúncio era quase sempre redigido num tom que demonstrava certa familiaridade do senhor com seu escravo (SCHWARCZ, 2001, p.141).

\footnotetext{
${ }^{31}$ São essas "descrições das figuras, falas e gestos" dos negros e mestiços presentes nos anúncios que Freyre destaca como sendo as bases de muitas de suas análises e interpretações de caráter antropológico e cultural (FREYRE, 1985, p.XV).
} 
Fugio da cidade de Itapetininga o escravo de nome Luiz, cabra 22 annos, altura regular e corpulento, pés grandes, cabellos grenhos, olhos vivos e pequenos, falta de dentes na frente, sabe ler e escrever regularmente, falla bem e muito explicado, muito risonho e fica sempre com papeias nas algibeiras de recitar versos, é pedreiro e copeiro e costuma dizer que é forro, anda descalço. É de Macahé, Rio de Janeiro (Província de São Paulo, 18/08/1877).

Próximo a essa imagem do escravo urbano estavam os escravos domésticos, que vivendo na casa-grande ao lado dos seus senhores, recebiam tratamento diferenciado, sendo descritos como indivíduos de boa figura, sem grandes defeitos físicos e com certo conhecimento ou especialização. E apesar da condição de propriedade não ser questionada, muitas vezes havia “um certo tom passional” nos anúncios (SCHWARCZ, 2001, p.143-144).

Fugiu Américo, crioullo de 38 a 39 annos, alto e bem feito de corpo, bons dentes, costuma fazer a barba, usa bigode, conversa bem, traja bem é bom carpinteiro e pedreiro, leva consigo algum dinheiro que é seu, é bonito é escravo de estimação (Província de São Paulo, 27/03/1877).

Radicalmente diferente era a imagem do escravo rural. Esses anúncios, que constituíam a maioria absoluta, destacavam-se por serem vagos e pouco detalhados (não detalhavam cabelo, idade, altura, cor), denunciando que o senhor pouco conhecia seus escravos. Mais do que isso, reiteravam-se de maneira constante os defeitos físicos dos negros, que poderiam advir tanto do trabalho árduo, como dos castigos e torturas a que eram submetidos (SCHWARCZ, 2001, p.147): “Deolindo natural de Bahia, signaes de castigo nas nádegas, alto e corpo regular (...) idade de 40 annos mais ou menos (...) fugiu com pegas e ganchos e quando tenha tirado deve existir os sinais de ferros...” (Correio Paulistano, 28/01/1874).

Vale dizer que apesar da grande maioria dos anúncios terem como foco escravos do sexo masculino, alguns poucos se referiam à fuga de escravas. As mulheres eram em geral descritas a partir de sua aparência e de seu caráter meigo ou serviçal, indicando por vezes uma relação mais íntima entre o senhor e sua cativa. Nesses casos, não se costumava mencionar sinais de castigo e a gratificação oferecida para quem encontrasse a escrava era normalmente inferior à oferecida por escravos do sexo masculino (SCHWARCZ, 2001, p.140).

Escrava fugida - De José Antonio de Souza residente em Itú fugiu há 5 mezes a escrava Balbina, mulata de 30 annos, estatura pequena, rosto comprido, cabelos não bem pretos, bonita figura, prosa de corpo, bons dentes, fala com doçura e em umas das faces, abaixo do olho, tem uma cavidade mui pequena (Correio Paulistano, 06/01/1886).

Já no que concerne à idade, as crianças (os “moleques”) eram descritas como pessoas vivas e espertas, enquanto os idosos eram caracterizados pelos seus defeitos físicos (mancos, gagos, aleijados) e pelo envelhecimento precoce, já que muitas vezes cativos com cerca de 
quarenta anos possuíam “cabelos e sobrancelhas embranquecidas” e “andar curvado e vagaroso” (SCHWARCZ, 2001, p.141).

Moleque fugido - Desde quinta-feira anda fugido o escravo Silvestre, natural do Ceará, levou calça embranquecida. Costuma dar-se por livre, mudar de nome e alugar-se para qualquer serviço (...), finge de humilde para iludir quando é surpreendido torna a fugir (Província de São Paulo, 25/04/1878).

Os anúncios relativos à venda, locação e leilão de escravos também eram comuns e numerosos nos jornais da época. Nestes, os anunciantes procuravam ressaltar os atributos positivos dos cativos, principalmente no que tange às características físicas, morais e conhecimentos profissionais.

ATTENÇÃO - Vende-se para o mato uma preta da costa de idade quarenta e tantos annos, muito sadia e bastante robusta, sabe bem lavar e cozinhar o diário de uma casa, vende-se em conta por haver precisão, no beco do Largo, n. 2, na mesma casa em que se vende tartaruga verdadeira (FREYRE, 1985, p.9).

Escravos bons - Vende-se 3 excellentes escravos, sendo: um moleque de 16 para 17 annos de idade, bonita figura, outro de 35 annos, habilíssimo, destro de serviço de lavoura e uma creoulla de 14 para 15 annos, bonita estampa (Correio Paulistano, s/d).

Os escravos eram apresentados como objetos, e recebiam, no que se refere à linguagem, o mesmo tratamento dos outros produtos anunciados. Assim, além de serem "valorizados” pela força, robustez e habilidade para o trabalho, os escravos eram comumente anunciados como "peças em liquidação”, “ofertas especiais” ou "bonito lote” (SCHWARCZ, 2001, p.135): “Escravos - Na rua da consolação, 72, há 28 'peças’ para vender (...) todas bonitas peças. Vende-se barato para liquidar” (Correio Paulistano, 09/05/1880).

Muitos desses anúncios buscavam valorizar seu "produto” não apenas pela afirmação das qualidades físicas e habilidades, mas também pela negação de atributos pejorativos normalmente associados aos negros, tais como vícios, vagabundagem e insubordinação (SCHWARCZ, 2001, p.136): "Excellente escravo - Vende-se creoulo de 22 annos, sem vícios, muito fiel, bom e aceado (...) é o melhor trabalhador de roça que se pode desejar, humilde obediente, bonita figura...” (Província de São Paulo).

Desse modo, enquanto nos anúncios de fuga predominava a imagem de ser bestial comumente atribuída aos negros, nos classificados os anunciantes buscavam "exaltar as características positivas dos cativos oferecidos” (garantindo assim a excepcionalidade da “mercadoria”) e afastar deles o “estigma” da escravidão (SCHWARCZ, 2001, p.136-137).

Considerando, então, a literatura ficcional, as notícias e os anúncios de jornais do século XIX, podemos perceber que a imagem do negro na produção cultural oitocentista, ainda que estivesse sempre (ou quase sempre) ligada à escravidão, não era única. No entanto, 
apesar da pluralidade de imagens, havia como predicado comum a todas elas uma insistente caracterização do negro como ser nocivo e incompatível com a civilização.

\section{4 - O século XX e o registro branco do Brasil}

Fato é que, ao valorizar ostensivamente a cultura e o biótipo europeu ao mesmo tempo em que escamoteava e estigmatizava os componentes negros da sociedade, as elites nacionais oitocentistas acabaram por cristalizar uma identidade nacional na qual a figura do branco foi normalizada.

Para Silva, "normalizar significa escolher - arbitrariamente - uma identidade específica como o parâmetro em relação ao qual as outras identidades são avaliadas e hierarquizadas”. A identidade normalizada passa a ser então aquela que concentra "todas as características positivas possíveis, em relação às quais as outras identidades só podem ser avaliadas de forma negativa” (SILVA, 2000, p.83).

Uma das principais características dessa normalização foi o estabelecimento daquilo que chamamos de registro branco do Brasil, que consiste, como descrevemos acima, no apagamento ou na detração da figura do negro nos espaços de representação simbólica assentamentos históricos, manifestações artísticas e produções acadêmicas e culturais - em favor de uma valorização da imagem do branco.

Se essa aspiração das elites ao branqueamento foi, retomando a idéia que tratamos no capítulo dois, "uma tentativa de preservar-se a discriminação contra eventuais efeitos colaterais da Abolição” (SODRÉ, 1999, p.87), é correto pensar que a manipulação da identidade e da diferença continuou a ter funcionalidade política depois do fim da escravidão.

O aparelho ideológico de dominação da sociedade escravista gerou um pensamento racista que perdura até hoje. Como a estrutura da sociedade brasileira, na passagem do trabalho escravo para o trabalho livre, permaneceu a mesma, os mecanismos de dominação inclusive ideológicos foram mantidos e aperfeiçoados (MOURA, 1988, p.23, grifo nosso).

Isso significa que durante o século XX o registro branco do Brasil perpetuou-se como paradigma de representação (e performatização) do "povo” brasileiro, caucionando um ideal de branqueamento que persistiu não apenas como meta, mas também como instrumento de manutenção de uma hierarquia social não mais garantida pela escravidão.

Entretanto, se durante o século XIX buscou-se o embranquecimento através da repressão (física e simbólica) do “outro nacional”, no século passado o que ocorreu foi a elaboração de uma “imagem de unidade conciliatória e não-conflitiva”, voltando aqui a Sodré (2001, p.81), por meio da diluição da questão do negro. 
É certo que nos primeiros anos do século $\mathrm{XX}$ as formas de representação do negro permaneceram ligadas a certos estereótipos oitocentistas, como o escravo fiel (que enfatizava a aceitação do negro de sua posição servil), o negro bestial (selvagem, bruto e libidinoso, inadequado, portanto), ou ainda a mulata lasciva, sexualizada (BROOKSHAW, 1983).

Contudo, a partir de meados da década de 1920, o movimento Modernista, em seu anseio de romper com o passadismo, volta-se para a elaboração de um "projeto de cultura" que contrapunha ao "Brasil real” uma "fantasia” que apontava para a modernização da sociedade, modernização esta que só viria com a valorização daquilo que fosse nacional (ORTIZ, 2001, p.35).

De acordo com Brookshaw, os modernistas foram os primeiros a reinterpretar supostas deficiências do povo brasileiro revertendo-as em superioridade (BROOKSHAW, 1983, p. 84). Assim, a mestiçagem - considerada até então como o grande mal do povo brasileiro - passou a ser vista e defendida como ponto positivo da nação:

... a antropofagia é a revolta da sinceridade recalcada durante quatrocentos anos. A reação da paisagem contra o tempo. Do nativo contra o importado. Do ingênuo contra o artificioso (...). Da terra (que é nossa), contra a estranha (de outros) ou o infinito (sem dono). (...) Da inferioridade do mestiço que trabalha contra a superioridade do ariano corroído pelo vício e pela moleza das decadências (BROOKSHAW, 1983, p. 84).

Essa passagem da Revista de Antropofagia (14/04/1929) deixa claro, na opinião de Brookshaw, que os modernistas defendiam claramente os componentes mestiços da população, mas não faziam o mesmo com relação ao negro e ao índio: “o afro-indígena (o elemento exótico) era 'o nativo', 'o ingênuo', (...) mas não um ser humano de carne e osso para defender socialmente. A defesa social e racial era feita a favor do mestiço e não do negro ou do índio” (BROOKSHAW, 1983, p. 83-84).

Para Jean-Yves Mérien é a obra Macunaíma (1928), de Mário de Andrade, que mostra de forma emblemática a atitude dos modernistas em relação aos negros: "sincretismo, virtudes da miscigenação e da fusão das três raças, com uma clara atitude preconceituosa em relação à raça negra” (MÉRIAN, 2008, p.54):

Nesta obra há passagens em que o discurso de rebaixamento do negro fala pela voz do narrador, como na famosa cena do branqueamento do herói, em que a água mágica "lava” o "pretume” da pele... Na seqüência, o irmão se joga sofregamente na mesma água, mas esta já estava "muito suja da negrura do herói”... e o irmão "só conseguiu ficar da cor do bronze novo (MÉRIAN, 2008, p.54).

Merién admite que o movimento modernista promoveu uma certa reabilitação do negro ao reconhecer, no plano cultural, a “contribuição” dos afrobrasileiros na construção da 
identidade nacional. No entanto, ressalva que no modernismo não existiu espaço "para a expressão e difusão da cultura dos afro-brasileiros” (MÉRIAN, 2008, p.54).

A década de 1930 foi particularmente relevante no que tange à consolidação da imagem de um Brasil mestiço. Naquele momento, além da “apologia” modernista, o mestiço passou a encarnar a "nova visão do homem brasileiro" desejada pelo Estado getulista (BARBALHO, 2007, p.3).

Após a “Revolução de 30”, Getúlio Vargas assume o governo preocupado não apenas em unir o país em torno de um poder central, mas também em criar um sentimento de "brasilidade”. E o nascimento desse sentimento pátrio, bem como a formação do "caráter nacional”, desejado por Vargas, passava necessariamente pelo resgate da imagem do mestiço, parcela majoritária da população que carregava ainda o estigma de ser inferior (BARBALHO, 2007, p.3-4).

Era fundamental, portanto, romper com a leitura dominante que depreciava o brasileiro e elaborar um discurso contrário à "ineficiência inata” do povo. Segundo Alexandre Barbalho, é esse o momento em que "os intelectuais a serviço do regime” se apegam ao livro Casa Grande e Senzala (1933), de Gilberto Freyre, exatamente porque o autor convertia “em positividade o que antes era negativo” e dava, através da ideologia da mestiçagem, o respaldo teórico necessário à elaboração de um discurso de valorização do mestiço (BARBALHO, 2007, p.4). Como coloca Munanga:

... ao transformar a mestiçagem num valor positivo e não negativo sob o aspecto da degenerescência, o autor de Casa grande e senzala permitiu completar definitivamente os contornos de uma identidade que há muito vinha sendo desenhada. Freyre consolida o mito originário da sociedade brasileira configurada num triângulo cujos vértices são as raças negra, branca e índia. (...) As três raças trouxeram também suas heranças culturais, paralelamente aos cruzamentos raciais, o que deu origem a uma outra mestiçagem no campo cultural. Da idéias dessa dupla mistura, brotou lentamente o mito da democracia racial (MUNANGA, 1999, p.76-77).

Munanga aponta que o mito da democracia racial exalta a idéia de convivência harmoniosa entre os indivíduos das diferentes classes sociais e grupos étnicos, permitindo às elites dominantes dissimular desigualdades e encobrir os conflitos raciais, o que possibilita a todos se reconhecerem como brasileiros e afasta dos segmentos subalternos "a tomada de consciência de suas características culturais que teriam contribuído para a construção e expressão de uma identidade própria” (MUNANGA, 1999, p.77).

É importante lembrar que dentro do projeto de construção da nação haurido por Vargas, os meios de comunicação de massa eram vistos como peças estratégicas, tanto para a 
educação do povo quanto para a transmissão da palavra oficial. Não por caso que sob a égide do estado novo é que tem início o desenvolvimento dos veículos de comunicação no Brasil.

O rádio, que havia sido introduzido no país em 1922, se expande e passa a assumir um formato comercial a partir de 1932, justamente quando o Estado autoriza a inserção de publicidade na programação, o que deu às emissoras uma fonte de financiamento constante. $\mathrm{O}$ cinema torna-se um bem de consumo ainda nas décadas de 1940 e 1950, mesmo período em que o mercado de publicações se amplia com o aumento do número de jornais, revistas e livros publicados ${ }^{32}$. A televisão chega ao Brasil em 1950 com pouca estrutura. Mesmo assim, experimenta um rápido crescimento: em 1951 o país contava com aproximadamente 3,5 mil aparelhos de TV, número que sobe para 141 mil em 1955 e 434 mil em 1959 (ORTIZ, 2001).

Isso quer dizer que o período de incipiência daquilo que viria a ser a indústria cultural brasileira ocorre no mesmo momento em que as elites nacionais procuram apagar a questão racial e reforçar o ideal de branqueamento valorizando a mestiçagem. E por "nascerem” inseridos nesse contexto é que os meios de comunicação se desenvolvem e se consolidam (já nos anos de 1960) reproduzindo/atualizando o registro branco do Brasil.

Como afirma Joel Zito Araújo:

Na história das nossas mídias audiovisuais, o desejo de branqueamento da nação, ideário que já estava consolidado desde o século XIX, acabou por se tornar um peso imagético, uma meta racial que nunca provocou rebeldias. Ao contrário, tornou-se convenção e naturalizou-se como estética audiovisual de todas as mídias, incluindo-se especialmente a TV, o cinema e a publicidade (ARAÚJO, 2006, p.73).

De fato, os diversos estudos dedicados a compreender as relações do negro com os meios de comunicação são (praticamente) unânimes em afirmar que, de um modo geral, o negro pouco aparece na mídia, e nas raras vezes em que isso acontece é quase sempre apresentado sob estereótipos pejorativos ou subalternizantes.

Umas das primeiras pesquisas relacionadas a esse tema foi realizada por João Baptista Borges Pereira, ainda na década de 1960. Em seu trabalho Cor, Profissão e Mobilidade: o negro e o rádio de São Paulo, Borges Pereira aponta que no rádio a personagem negra esteve sempre associada à imagem do negro caricatural, estereótipo este que era estilizado com base em alusões à estética (macaco, feito, tição); à “descategorização social” (malandro, rufião, delinqüente, maloqueiro, bêbado, vagabundo, servil); ou ainda a certas qualidades

\footnotetext{
32 O cinema se desenvolve não apenas por conta da penetração de filmes estadunidenses, mas também por conta da criação de uma cinematografia nacional, com a fundação da Atlântida (1941) e da Vera Cruz (1949). O mercado de publicações também teve franco crescimento nessa época, a exemplo da revista Cruzeiro que em

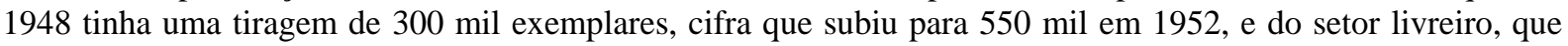
cresceu 300\% entre 1938 e 1950 (ORTIZ, 2001, p.42-43).
} 
consideradas “positivas” (talento para a música, astúcia, ingenuidade) (BORGES PEREIRA, 2001, p.178).

Solange Martins Couceiro de Lima, já na década de 1970, dá continuidade ao trabalho de Borges Pereira ao estudar a participação do negro na televisão ${ }^{33}$. Em sua pesquisa Couceiro identifica que na TV, assim como em outros veículos, “o negro representa os mesmos papéis que na sociedade brasileira lhe têm sido atribuídos pelo processo histórico” (COUCEIRO DE LIMA, 1983, p.86), ou seja, são retratados, na maior parte das vezes, como indivíduos "subalternizados ou desqualificados, delinqüentes, ridicularizados, risíveis, malandros, promíscuos, imorais, primitivos, espetaculosos, bufões, ex-cativos etc” (BORGES PEREIRA, 1983, p.140).

É interessante notar como apesar do distanciamento cronológico, a pesquisa de Couceiro permanece atual. Jacques d’Adesky, em trabalho duas décadas posterior, coloca que nas novelas e séries televisivas os negros são quase invisíveis, raramente aparecem como protagonistas e na maior parte das vezes em que aparecem "é para fortificar a trama da história dominante, seja por meio de imagens exóticas, pela construção de uma intriga racial ou por imagens banais de motoristas ou delinqüentes” (D’ADESKY, 2001, p.89).

Com efeito, o caso da telenovela, "produto de maior importância da indústria cultural” (COUCEIRO DE LIMA, 2001, p.89), é emblemático. Aponta Araújo:

Em poucos trabalhos identificamos atores negros nos papéis principais, de protagonistas ou antagonistas (...). De um modo geral, ao ator afro-brasileiro estão reservados os personagens sem, ou quase sem, ação, os personagens passageiros, decorativos, que buscam compor o espaço da domesticidade, ou da realidade das ruas, em especial das favelas (ARAÚJO, 2000, p.308).

E no cinema a situação do negro brasileiro é a mesma da televisão: é comumente mostrado como subalterno, marginal ou associado ao que não é cotidiano, como a religião, as festas e o carnaval (D’ADESKY, 2001, p.94). Em outras palavras: “Os cerca de $40 \%$ dos brasileiros de origem mestiçada não têm encontrado seu reflexo proporcional no cinema nacional, que curiosamente trata como exceção exótica quase metade da população do país” (RODRIGUES, 2001, p.107).

O caso da publicidade não é diferente. D’Adesky ao discutir a presença de negros nos anúncios comerciais da década de 1990, afirma que a “publicidade traduz também o estado de

\footnotetext{
${ }^{33}$ A televisão é hoje, sem dúvida, o veículo de comunicação que atinge o maior número de pessoas no Brasil. Uma pesquisa realizada pela Eletrobrás (Centrais Elétricas Brasileiras) divulgada em abril de 2007 aponta a existência de pelo menos um aparelho de televisão em $97,1 \%$ dos domicílios brasileiros (http://www1.folha.uol.com.br/folha/Dinh eiro/ult91u116233.shtml). D’Adesky (2001, p.88) afirma que a cobertura da Rede Globo, por exemplo, alcança 99,4\% das cidades e municípios no país.
} 
exclusão e de quase invisibilidade a que estão sujeitas as populações negras e pobres”. O autor observa que os anúncios raramente mostram negros, e que nas poucas vezes em que aparecem têm sua imagem ligada a certas "formas marcantes": o negro hilariante, normalmente um comediante ou um “performático”, a exemplo do Sebastian, o garoto propaganda das lojas C\&A; o vigor físico, tanto do ponto de vista sexual como atlético; e o segundo plano, cujo negro, estereotipado ou não, aparece sempre ao fundo, quase invisível (D’ADESKY, 2001, p.103-104).

Anos antes, Carlos Hasenbalg, em seu artigo As imagens do negro na publicidade (1982), chegava a conclusões bastante semelhantes: “o negro é representado ora como trabalhador braçal, não qualificado, ora como aquele que ascendeu socialmente pelos canais de mobilidade considerados legítimos para o negro”, ou seja, jogadores de futebol, artistas, e cantores. E tais tipificações remeteriam a outro elemento comum, condensado pelo autor como "atributos do corpo: vigor e resistência física, ritmo e sexualidade” (HASENBALG, 1982, p.184).

Não é difícil perceber que muitos dos estereótipos até agora apresentados se repetem (com eventuais variações) nos distintos veículos de comunicação. Da mesma forma, não é difícil perceber certa persistência de alguns desses estereótipos ao longo dos anos, já que os resultados de diferentes pesquisas realizadas nas décadas de 1960, 1970 ou 1990 apresentam resultados bastante parecidos.

É exatamente esse o ponto que buscaremos trabalhar a partir do próximo capítulo. Nosso objetivo é estudar a participação do negro na publicidade brasileira num período que compreende os anos finais do século XX e os primeiros anos do século XXI, buscando apresentar dados quantitativos e qualitativos que possam, de alguma maneira, contribuir com o debate sobre invisibilidade e estereotipação iniciado em pesquisas anteriores.

A proposta é mensurar a aparição de negros nos anúncios comerciais e em seguida identificar e analisar os estereótipos sob os quais o negro aparece representado, de modo que seja possível apontar permanências e rupturas tanto no que diz respeito à quantidade, como no tange ao discurso.

Aventamos aqui a hipótese de que a despeito de toda a discussão em torno da questão racial que tem sido levada a cabo por intelectuais, entidades do movimento negro, e até mesmo pelo Poder Público nos últimos 30 anos, a publicidade nacional (assim como outros segmentos da mídia) permaneceu com um "enfoque racial” eurocêntrico - fruto da incorporação do mito da democracia racial brasileira e da ideologia do branqueamento 
(ARAÚJO, 2001, p.40) - apresentando pouca melhora nas condições de visibilidade e representação dos indivíduos escuros dentro do período proposto.

Em outras palavras, tentaremos demonstrar que mesmo com os mais de cem anos que nos separam da Abolição da Escravatura, o discurso midiático (e publicitário, em especial) reproduz, de maneira atualizada, o registro branco do Brasil forjado no século XIX, escamoteando a presença do negro e retratando-o com base em releituras de estereótipos oitocentistas. 


\section{O NEGRO NA PUBLICIDADE BRASILEIRA}

Empresários, publicitários e produtores de tevê, como norma, optam pelo grupo racial branco, nos processos de escolha de modelos publicitários, na estética da propaganda e até mesmo nos critérios de patrocínio ou apoio a projetos culturais.

Joel Zito Araújo

Se o período de incipiência da mídia brasileira deu-se num momento em que se pretendia acobertar as questões raciais e tirar o negro da cena social, a consolidação dos veículos de comunicação enquanto elementos de uma indústria cultural tampouco ocorreu em momento muito favorável à população negra.

É nas décadas de 1960 e 1970, ou seja, em pleno período de Ditadura Militar, que se estrutura no país um "mercado de bens culturais”. Isso significa que cinema, televisão, publicidade e outras esferas de produção cultural se constituíram enquanto indústria justamente no momento "em que o estado autoritário tem interesse em eliminar os setores que possam lhe oferecer resistência”. Nesse sentido, aponta Ortiz, a repressão aos partidos políticos, aos movimentos sociais e à liberdade de expressão contribuiu seguramente para que formas críticas de expressão cultural fossem desmanteladas (ORTIZ, 2001, p.155).

Como destaca Barbalho, do ponto de vista cultural não interessava ao regime militar romper radicalmente com o passado, motivo pelo qual os militares acabam por “dar continuidade ao pensamento sobre a cultura nacional estabelecido durante o governo Vargas (...)” (BARBALHO, 2007, p.5).

Assim, no discurso dos “ideólogos do regime militar” a diversidade não é descartada, e a miscigenação revelaria "uma realidade sem contradições, já que o resultado do encontro entre as culturas passa por cima das possíveis divergências, e acaba por qualificar a cultura brasileira como democrática, harmônica, espontânea, sincrética e plural” (BARBALHO, 2007, p.6).

Nesse sentido, optamos por posicionar o marco inicial de nosso trabalho em 1985, ano do início da redemocratização do país, e época na qual os movimentos políticos e sociais, incluindo o movimento negro, puderam ter uma atuação menos restrita - podendo-se dizer o mesmo das manifestações artísticas e culturais.

De fato, é a partir dos anos 1980 que avanços significativos na questão racial são conquistados. As primeiras iniciativas oficiais no sentido de reconhecer a existência de discriminação racial no país e a necessidade de se resguardar a história e a cultura do negro ocorrem naquele período. É na gestão de Franco Montoro, governador de São Paulo entre 
1982 e 1986, que se criam o Conselho de Participação e Desenvolvimento da Comunidade Negra e, dentro da Secretaria de Cultura, a Assessoria de Assuntos Afro-Brasileiros (ANDREWS, 1998, p.321). Do governo federal veio, em 1984, o decreto que elevou a Serra da Barriga (ponto onde se localizava o Quilombo do Palmares) ao status de patrimônio histórico nacional.

O Centenário da Abolição da Escravatura, em 1988, foi um marco na luta anti-racista nas décadas finais do século XX. Além de suscitar discussões acadêmicas e nas imprensas nacional e norte-americana, e manifestações populares como marchas e passeatas, o Centenário impulsionou a criação de órgãos governamentais como a Fundação Cultural Palmares (Ministério da Cultura) no mesmo ano, e a Secretaria Extraordinária de Defesa e Promoção das Populações Afro-Brasileiras no Rio de Janeiro, em 1991.

Nesse mesmo período, se promulgam, por exemplo, a lei Caó (lei $n^{\circ}$ 7.716/89), de autoria do deputado federal Carlos Alberto “Caó” de Oliveira, dispositivo legal que transformou em crime atos resultantes de discriminação racial (substituindo a lei Afonso Arinos, da década de 1950, que tipificava os atos de discriminação como contravenção penal), e a Constituição do Estado da Bahia, que trazia já em 1989 um capítulo específico sobre o negro, no qual, entre outras coisas, estabelecia cota para o negro na publicidade oficial e instituía o dia 20 de novembro como dia da consciência negra.

Vale lembrar, também, que muitas instituições de caráter não governamental também nasceram nessa época: o Geledés (Instituto da Mulher Negra), situado em São Paulo, é de 1988; o CEAP (Centro de Articulação de Populações Marginalizadas) foi fundado no Rio de Janeiro em 1989; em Belo Horizonte, temos a Casa Dandara, fundada em 1987; e o CEERT (Centro de Estudos de Relações de Trabalho e Desigualdade) foi fundado em 1990, em São Paulo (D’ADESKY, 2001, p.155-156).

Outro marco importante foi a celebração dos 300 Anos da Morte de Zumbi dos Palmares, em 1995. As questões raciais que vinham sendo debatidas desde 1988 voltaram a ganhar espaços na sociedade e na mídia, e a pressão sobre o Poder Público - destacando aqui a Marcha Zumbi contra o Racismo, pela Cidadania e a Vida - leva o governo federal a criar, em 20 de novembro, um grupo de trabalho interministerial "para desenvolver políticas de valorização e promoção da população negra”, incluindo aí ações afirmativas (MOEHLECKE, 2002, p.206). E nessa mesma data foi que o então presidente Fernando Henrique Cardoso reconheceu oficialmente Zumbi dos Palmares como herói nacional ${ }^{34}$.

\footnotetext{
${ }^{34}$ http://almanaque.folha.uol.com.br/cotidiano_21nov1995.htm
} 
Com efeito, é a partir de 1995 que a discussão em torno das ações afirmativas ganha corpo nos diversos setores sociais. Vários foram os projetos de lei apresentados ou aprovados nesse período (como as leis $n^{\circ}$ 2325/95 e $n^{\circ}$ 6769/95, que estabelecem cotas nos anúncios publicitários encomendados pelas prefeituras do Rio de Janeiro e Belo Horizonte, respectivamente, ou a lei no 9156/95 que oficializa o Hino à Negritude no estado de São Paulo), isso sem falar nos eventos promovidos pelo Instituto de Pesquisas Econômicas Aplicadas (Ações Afirmativas: estratégias antidiscriminatórias) e pelo Ministério da Justiça (Multiculturalismo e racismo: o papel da ação afirmativa nos estados democráticos contemporâneos) em 1996.

Apesar de tudo, somente em 2001 uma política de ação afirmativa começou a ser implantada no país. O Ministério do Desenvolvimento Agrário estabeleceu cota de 20\% para negros na estrutura organizacional do Ministério, do INCRA e das empresas prestadoras de serviço. De lá pra cá, diversas outras ações tornaram-se efetivas, seja nos ministérios, nas universidades públicas estaduais e federais e até mesmo no Instituto Rio Branco - responsável por formar o corpo diplomático brasileiro (MOEHLECKE, 2002, p.209).

O marco final do nosso estudo é o ano de 2005, escolhido não apenas em razão de ser o ano em que protocola o Projeto de Lei ${ }^{\circ}$ 6.264, do senador Paulo Paim, propondo a criação do Estatuto da Igualdade Racial, mas também por contemplar a fundação da Secretaria Especial de Promoção da Igualdade Racial (SEPPIR), criada pelo presidente Luís Inácio Lula da Silva em 2003 com a missão “de estabelecer iniciativas contra as desigualdades raciais no País” - usando aqui as palavras da Presidência da República ${ }^{35}$.

Acreditamos ser este um período demasiado importante na história do negro brasileiro, não apenas pelo valor simbólico das efemérides, mas por toda uma mobilização que acabou por gerar frutos nos mais diversos setores sociais, incluindo aí a saúde (com as campanhas sobre a anemia falciforme, por exemplo), a educação e o mercado de trabalho.

Resta saber, e é isso que discutiremos, em que medida toda essa mobilização social produziu efeitos no discurso midiático. Optamos então por trabalhar com a publicidade nacional - dada a sua relevância, como já tratamos no início do trabalho - e para tanto compusemos uma amostra significativa de anúncios comerciais e adotamos procedimentos metodológicos os quais descreveremos a partir de agora.

\footnotetext{
${ }^{35}<$ http://www.presidencia.gov.br/estrutura_presidencia/seppir/sobre/> Acesso em 14/09/2009 às 04h30.
} 


\section{1 - Definição da amostra}

A publicidade é um segmento da mídia extremamente diversificado e presente nos mais variados veículos de comunicação, dos meios impressos à televisão, fato este que dificulta a composição de um corpus documental que abranja numa mesma pesquisa todas as suas facetas.

Dentro das várias possibilidades, optamos por trabalhar com publicidade veiculada em mídia impressa (revistas mais especificamente) tendo em vista, a priori, a facilidade de acesso. As redes de televisão raramente arquivam os anúncios por elas veiculados, e buscá-los nos anunciantes ou nas agências inviabilizaria logística e metodologicamente a pesquisa. Por outro lado, são muitos os centros de documentação e bibliotecas que possuem em seus acervos coleções completas dos principais periódicos do país.

Outro fator importante que influenciou nossa decisão foi o estudo intitulado Media Choices 2000: A Multimedia Involvement Study, realizado pela organização norte-americana Magazine Publishers of America (MPA). Segundo os resultados dessa pesquisa, a publicidade inserida em revistas é aquela na qual o consumidor estadunidense mais confia, e 70\% dos oito mil entrevistados mostraram-se mais dispostos a prestar atenção na publicidade contida em revistas do que em outros meios de comunicação.

Levamos em conta também estudo da consultoria internacional Nielsen (publicado em outubro de 2007) que apontou não apenas que o brasileiro “é o povo que mais acredita em publicidade”, com 67\% dos entrevistados dizendo confiar em anúncios de um modo geral, mas também que destes, $80 \%$ confiam nos anúncios veiculados em revistas ${ }^{36}$.

Por último, devemos lembrar que, segundo o Ibope, as revistas concentram cerca de 10\% dos investimentos em veiculação de anúncios comerciais (aproximadamente R\$ 5,5 milhões em 2008), ficando atrás somente das emissoras de TV e dos jornais ${ }^{37}$.

Uma vez definido que focaríamos nossa pesquisa em revistas, estabelecer qual (ou quais) publicação comporia o universo de pesquisa foi nosso segundo passo. A grande dificuldade nessa etapa foi estabelecer um critério de escolha, uma vez que o mercado de revistas é extremamente diversificado e direcionado a públicos bastante segmentados.

Nossa intenção era de trabalhar com uma revista de caráter abrangente, que não fosse voltada especificamente aos públicos masculino/feminino (como Men’s Health, Placar,

\footnotetext{
${ }^{36}$ Fonte: http://vejaonline.abril.com.br/notitia/servlet/newstorm.ns.presentation.NavigationServlet?publica tion Code=1\&pageCode=1\&textCode=131882\& currentDate=1191333300000 $>$ Acessado em 19/05/2008.

${ }^{37}$ Fonte: <www.almanaqueibope.com.br> Acessado em 16/09/2009.
} 
Playboy, Marie Claire, Criativa), a executivos (Você S/A, Exame), ou a adolescentes (Capricho, Atrevida).

Nesse sentido, pensamos que uma revista de informação seria a opção mais adequada, e dentre todas elegemos o semanário Veja, do Grupo Abril, tendo em vista dois fatores: primeiramente, a Veja é a maior revista brasileira tanto em tiragem (média de 1,1 milhão de exemplares), como em número de leitores (8,8 milhões aproximadamente), tendo circulação nacional e forte presença nas principais regiões metropolitanas do país.

Além disso, o público leitor é bastante abrangente e equilibrado em relação a sexo e idade, sendo $45 \%$ de homens e 55\% de mulheres, dos quais 15\% na faixa dos 10-19 anos; 23\% na dos 20-29; 20\% na dos 30-39; 20\% na dos 40-49; e 22\% com 50 anos ou mais.

É importante ressaltar (e ressalvar) o forte caráter elitista da revista, que tem $80 \%$ de

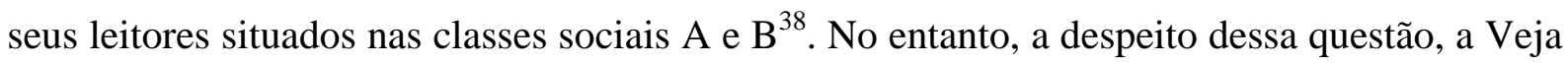
é, pelo menos estatisticamente, o semanário que atinge o maior número de brasileiros, chegando, inclusive, a ter penetração nas classes C (16\%), D e E (4\%) $)^{39}$.

Ao focarmos nosso estudo em um só veículo de comunicação, ainda que seja o maior ou o mais lido, fica claro que não buscamos constituir uma amostra representativa da publicidade nacional. Como esclarece Maria Immacolata Vassallo de Lopes, representativa, ou probabilística, é aquela que “baseia-se na aplicação de métodos de tratamento estatístico”. Nossa amostra, portanto, deve ser classificada como significativa ou de representatividade social, pois não se apóia em métodos estatísticos, mas nos permite identificar nuanças e tendências (LOPES, 2005, p.144-145).

Nessa linha, também não nos interessava cobrir todo o intervalo proposto (1985 a 2005), tampouco fazer a observação de todos os números publicados. Acreditamos que seria mais interessante comparar resultados com algum distanciamento entre os anos analisados o que permitiria notar mais claramente as possíveis variações. Da mesma forma, analisar todos os números da revista publicados num mesmo ano (52 em média) pouco interferiria no resultado final da pesquisa.

Assim, estabelecemos que comporíamos nossa amostra com base em intervalos de cinco anos a partir do marco inicial (1985, 1990, 1995, 2000 e 2005) e dentro de cada ano

\footnotetext{
${ }^{38}$ A divisão sócio-econômica da população em classes sociais que vão de A a E é uma categorização utilizado pelo IBOPE (Instituto Brasileiro de Opinião Pública e Estatística) em pesquisas de mercado e de opinião. O chamado de Critério de Classificação Econômica Brasil, leva em conta dados como escolaridade, posse de bens duráveis e faixas de renda familiar, dividindo-se, basicamente, em 5 categorias: A (acima de R\$ 6.564), B (acima de R\$ 2.013), C (acima de R\$ 726), D (acima de R\$ 485) e E (acima de R \$ 277). Fonte: Associação Brasileira de Empresas de Pesquisa <http://www.abep.org/codigosguias/Criterio_Brasil_2008.pdf> Acessado em: 160/9/2009. 39 Dados fornecidos pela própria revista, com base nos Estudos Marplan, do instituto de pesquisas IpsosMarplan. Disponível em : <http://veja.abril.com.br/idade/publiabril/midiakit/> Acessado em: 16/09/2009.
} 
escolheríamos aleatoriamente uma edição de cada mês, o que significaria observar cerca de $25 \%$ das edições de cada ano.

\section{2 - Observação e tratamento das fontes}

A análise do corpus documental deu-se através da análise de todos os anúncios que continham, de alguma forma, a figura humana, seja ela real (atores, modelos) ou representada por desenhos (história em quadrinhos, charges). Foram incluídos também no corpus, os anúncios nos quais apenas partes específicas do corpo foram mostradas (braços, mãos, pés).

Em cada um dos exemplares analisados, o primeiro passo consistiu em contabilizar o número total de anúncios com figura humana e dentro desse universo quantos continham personagens negros. Contabilizamos também o número total de personagens negros e brancos em cada peça.

Num segundo momento, descartamos os anúncios em que não apareciam negros, e nos voltamos aos anúncios com negros, fazendo a catalogação de cada peça publicitária, anotando a data e a edição da revista, o anunciante (nome da empresa), a tipificação jurídica do anunciante (podendo ser público, privado ou organização não-governamental), produto anunciado, o total de personagens (negros e brancos) e o papel que o negro desempenha na peça publicitária. Por fim, fizemos o registro fotográfico dos respectivos anúncios.

A maior parte da coleta de documentos ocorreu na biblioteca da Escola de Comunicações e Artes da Universidade de São Paulo (ECA-USP), processo que contou com certas limitações e entraves burocráticos que não chegaram a comprometer a execução dos trabalhos, mas mostrou que a unidade não tem regras que favoreçam aos seus próprios pesquisadores. Os exemplares dos anos de 1985 a 2000, por estarem recolhidos na "Coleção Especial” têm acesso restrito, e tanto alunos da ECA, quanto pessoal externo só podem consultar o material com agendamento prévio (e são poucas vagas por dia) e por um período que não pode superar duas horas. Para minimizar o problema recorri à biblioteca da Faculdade de Economia e Administração (FEA), também da USP, na qual realizei a coleta nos exemplares dos anos de 2000 e 2005 com mais facilidade.

Uma vez que os documentos já estavam coletados, o passo seguinte foi consolidar os dados de maneira que pudemos verificar a variação no número de anúncios com negros, no número de personagens negros, na quantidade de peças com estereótipos desabonadores entre outros cruzamentos.

A propósito, cabe aqui ressaltar que o critério para classificar um personagem como negro ou como branco foi totalmente subjetivo e, com certeza, não escapa a possíveis 
questionamentos. Além disso, é importante dizer que optamos pela classificação binária negros/brancos não apenas por acreditarmos ser esta a mais adequada para uma pesquisa na qual a auto-classificação não é possível, mas também por seu sentido simbólico.

D’Adesky ao justificar a utilização do sistema classificatório binário negro/branco em seu trabalho afirma que na classificação branco/não-branco o termo não-branco não corresponde totalmente à denominação negro, define o negro pela negação e os designa por um ponto de vista etnocêntrico, ou seja, a partir do branco (D’ADESKY, 2001, p.34).

Por sua vez, a classificação negro/não-negro neutralizaria os efeitos negativos da expressão não-brancos, contudo, para o autor, essa mudança não passaria de um jogo de palavras, uma vez que categorias como não-negro e não-branco significam, respectivamente, branco e negro. Assim, d’Adesky prefere abandonar esses termos "para simplesmente retomar as categorias branco e negro” que julga serem mais adequadas (D’ADESKY, 2001, p.34).

... os termos branco e negro devem ser entendidos em nosso trabalho segundo sua dimensão de constructio social (...). Todavia, convém assinalar que esses termos são apreendidos numa dinâmica de interação que os submete a um campo ideológico constituído de estereótipos, de preconceitos que apresentam a imagem do negro inferiorizada em relação ao branco (D’ADESKY, 2001, p.34).

Tendo em vista o excerto citado, d’Adesky define os negros como populações de origem ou ascendência africana "subjulgadas a um cânone estético helênico, ao qual não se adaptam”. Esse cânone seria o reflexo de uma cultura hegemônica cuja imposição é altamente discriminatória, vez que "estabelece fronteiras entre o que é bonito e o que é feio, o que é desejável e o que não é, e o que é valorizado ou não” (D’ADESKY, 2001, p.34-35).

... podemos propor uma definição de negro como sendo todo indivíduo de origem ou ascendência africana suscetível de ser discriminado por não corresponder, total ou parcialmente, aos cânones estéticos ocidentais, e cuja projeção de uma imagem inferior ou depreciada representa uma negação de reconhecimento igualitário, bem como a denegação de valor de uma identidade de grupo e de uma herança cultural e uma herança histórica que geram exclusão e opressão (D’ADESKY, 2001, p.34).

É nesse sentido, portanto, que utilizamos a categorização binária branco/negro em nosso trabalho. Existe aqui uma oposição entre brancos e negros que corresponde à oposição entre dominadores e dominados ( $D^{\prime}$ ADESKY, 2001, p.34) e isso estará presente nos resultados que mostraremos a partir de agora.

\section{3 - Aspectos quantitativos}

Durante a coleta de dados foram analisados 60 exemplares da revista semanal Veja, nos quais encontramos 1158 anúncios com presença da figura humana, e desses 86 
apresentavam um ou mais negros, número que equivale a $7 \%$ do total. Com relação ao número de personagens, quantificamos 3186 no total, sendo 156 negros, ou seja, cerca de 5\%.

Se observarmos os números ano a ano perceberemos um aumento gradual no número de anúncios com negros. Partimos de 3\% em 1985 para chegarmos a 2005 com 13\%, o que significa que num intervalo de 20 anos o número de peças publicitárias nas quais aparece algum negro cresceu $10 \%$.

Podemos observar também que nos primeiros 10 anos pesquisados o número de anúncios com negros mais que dobrou, indo de 3\% a 7\%, enquanto nos 10 anos seguintes o número não chega a dobrar, mas salta de $7 \%$ para $13 \%$.

Tabela 1 - Número de anúncios com negros

\begin{tabular}{|c|c|c|c|}
\hline Ano & $\begin{array}{c}\mathbf{n}^{\mathbf{0}} \text { de anúncios } \\
\text { utilizando pessoas }\end{array}$ & $\begin{array}{c}\text { anúncios } \\
\text { com negros }\end{array}$ & \% \\
\hline $\mathbf{1 9 8 5}$ & 308 & 8 & $3 \%$ \\
\hline $\mathbf{1 9 9 0}$ & 163 & 7 & $4 \%$ \\
\hline $\mathbf{1 9 9 5}$ & 177 & 13 & $7 \%$ \\
\hline $\mathbf{2 0 0 0}$ & 263 & 26 & $10 \%$ \\
\hline $\mathbf{2 0 0 5}$ & 247 & 32 & $13 \%$ \\
\hline Total & $\mathbf{1 1 5 8}$ & $\mathbf{8 6}$ & $\mathbf{7 \%}$ \\
\hline
\end{tabular}

Com relação ao número de personagens negros, temos uma situação parecida. Apesar da diminuição de 9\% no ano 2000 para 7\% em 2005, o avanço, de um modo geral, é sensível, principalmente se considerarmos que em 1985 tal número não passava de 1\%.

Tabela 2 - Número de personagens negros

\begin{tabular}{|c|c|c|c|}
\hline Ano & $\begin{array}{c}\mathbf{N}^{\mathbf{0}} \text { total de } \\
\text { Personagens }\end{array}$ & $\begin{array}{c}\mathbf{n}^{\mathbf{0}} \mathbf{d e} \\
\text { personagens } \\
\text { negros }\end{array}$ & $\mathbf{\%}$ \\
\hline $\mathbf{1 9 8 5}$ & 839 & 9 & $1 \%$ \\
\hline $\mathbf{1 9 9 0}$ & 415 & 12 & $3 \%$ \\
\hline $\mathbf{1 9 9 5}$ & 508 & 27 & $5 \%$ \\
\hline $\mathbf{2 0 0 0}$ & 609 & 55 & $9 \%$ \\
\hline $\mathbf{2 0 0 5}$ & 815 & 53 & $7 \%$ \\
\hline Total & $\mathbf{3 1 8 6}$ & $\mathbf{1 5 6}$ & $\mathbf{5 \%}$ \\
\hline
\end{tabular}


É inegável, portanto, o aumento de negros na publicidade, tanto em números absolutos como em números relativos. Ainda assim, acreditamos ser importante quantificar, mesmo que de maneira pontual, outros aspectos:

a) gênero

Vale ressaltar que o crescimento no número de negros na publicidade tem um caráter masculino, ou seja, é a figura do homem negro que, em geral, prevalece. Como mostra a tabela abaixo, foram encontradas 57 personagens femininas e 87 masculinos, sendo que 12 personagens não puderam ser identificados ou por conta dos trajes que os cobria ou por causa da distância. Essa diferença foi maior no ano 2000, “coincidentemente” o ano em que mais se utilizou personagens negros, e no de 1990, o número de figuras femininas foi pouco maior que as masculinas.

Tabela 3 - Número de personagens negros (por gênero)

\begin{tabular}{|c|ccc|c|c|}
\hline Ano & $\begin{array}{c}\text { personagens } \\
\text { negros } \\
\text { (identificados) }\end{array}$ & $\begin{array}{c}\text { personagens } \\
\text { femininas }\end{array}$ & $\begin{array}{c}\text { personagens } \\
\text { masculinos }\end{array}$ & $\begin{array}{c}\% \\
\text { personagens } \\
\text { femininos }\end{array}$ & $\begin{array}{c}\% \\
\text { personagens } \\
\text { masculinos }\end{array}$ \\
\hline $\mathbf{1 9 8 5}$ & 7 & 2 & 5 & $29 \%$ & $71 \%$ \\
\hline $\mathbf{1 9 9 0}$ & 12 & 7 & 5 & $58 \%$ & $42 \%$ \\
\hline $\mathbf{1 9 9 5}$ & 24 & 9 & 15 & $38 \%$ & $62 \%$ \\
\hline $\mathbf{2 0 0 0}$ & 53 & 17 & 36 & $32 \%$ & $68 \%$ \\
\hline $\mathbf{2 0 0 5}$ & 48 & 22 & 26 & $45 \%$ & $55 \%$ \\
\hline Total & $\mathbf{1 4 4}$ & $\mathbf{5 7}$ & $\mathbf{8 7}$ & $\mathbf{4 0 \%}$ & $\mathbf{6 0 \%}$ \\
\hline
\end{tabular}

Sem desprezar o fato de existir uma predominância masculina, comparando os resultados ao longo do período é possível notar certa tendência ao equilíbrio no que se refere a gênero: se em 1985 a diferença entre personagens masculinos e femininos era de 42\%, em 1995 já havia caído para 24\% e em 2005 era de $10 \%$.

b) tipo de empresa anunciante e produto anunciado

Outra preocupação que tivemos foi saber em que medida os diferentes tipos de empresa (privada, pública ou ONG) utilizam o negro em seus anúncios. Obviamente nossa expectativa acabou se confirmando, já que as empresas privadas são os anunciantes mais freqüentes. Mesmo assim, foi interessante notar que quase $20 \%$ do total de anúncios que 
contêm negros são de empresas públicas ou de capital misto, e 12\% de entidades de caráter não-governamental.

Buscamos saber também que categorias de produto utilizam negros em seus anúncios. Para classificá-las procuramos trabalhar com categorias próximas - vez que nem todas puderam ser transpostas - às estabelecidas pelo IBOPE.

O resultado foi uma distribuição bastante ampla, encontrando o negro em peças publicitárias de produtos bastante diversificadas (aproximadamente 25), indo de higiene pessoal à informática. Mesmo assim, foi possível apontar algumas como as mais comuns. Abaixo, citamos e exemplificamos as principais:

- campanhas públicas governamentais: 9 ocorrências;

- campanhas de instituições assistencialistas e outras ONGs: 9 ocorrências;

- bancos e instituições financeiras: 9 ocorrências;

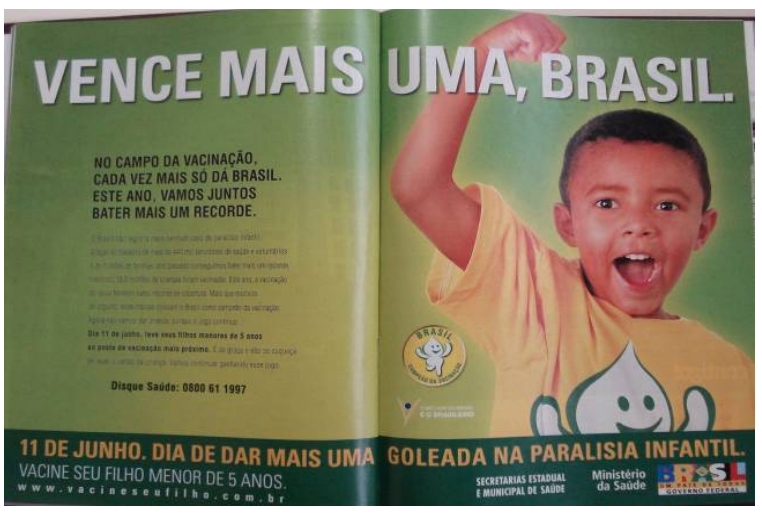

(Veja, 2005)

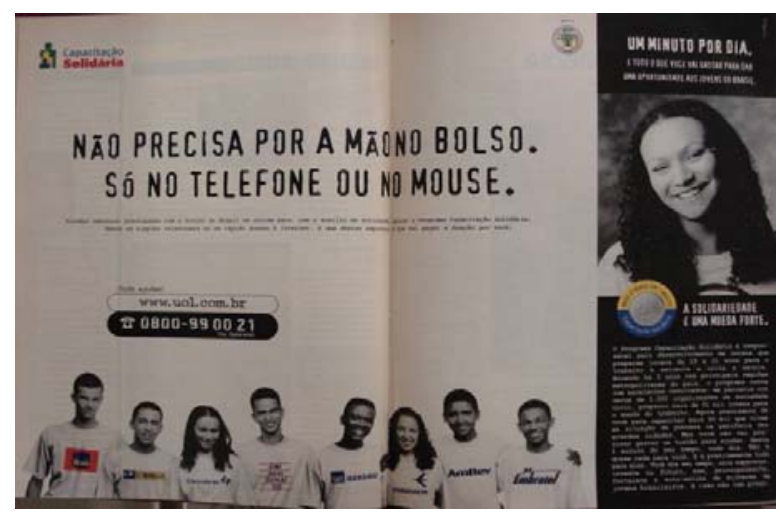

(Veja, 2000)

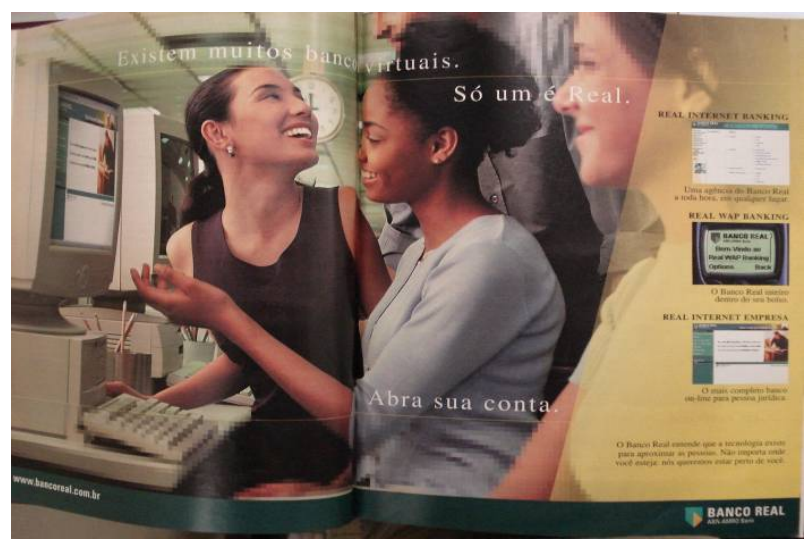

(Veja, 2000)

- produtos de mídia eletrônica (TV, TV a cabo, CDs): 8 ocorrências;

- produtos de mídia impressa (livros, revistas, jornais): 8 ocorrências; 


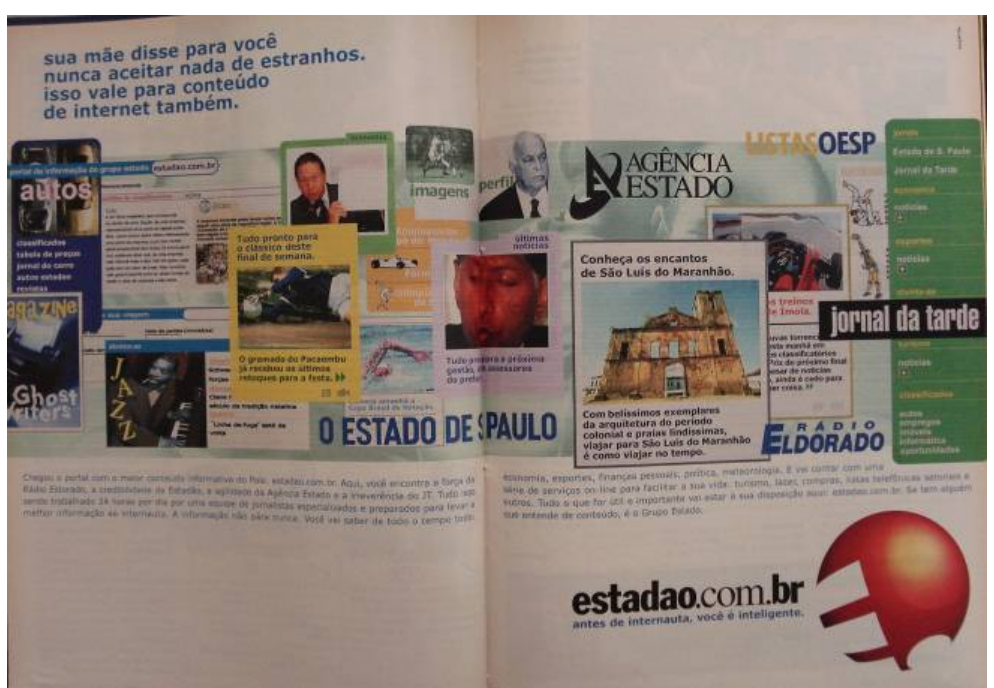

(Veja, 2000)

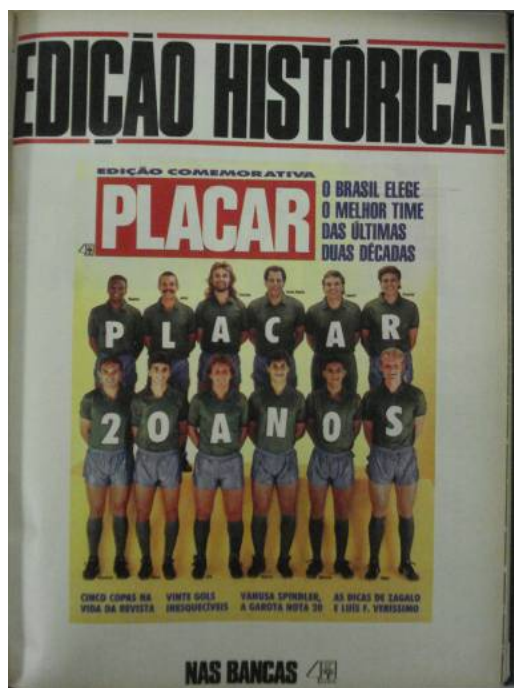

(Veja, 1990)

viagens e turismo: 5 ocorrências;

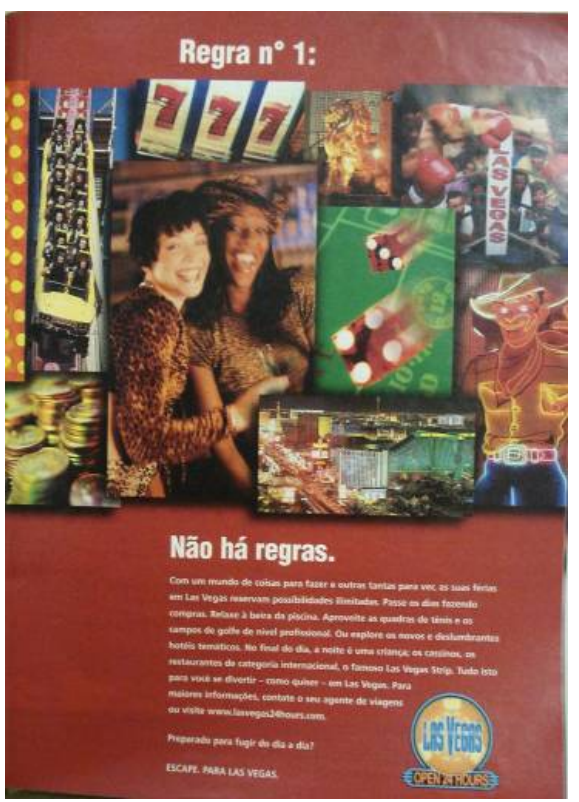

(Veja, 2000)

Podemos encontrar também outras categorias que apresentam certa recorrência, porém com menor intensidade, tais como telefonia fixa (3 ocorrências) cerveja, produtos de higiene pessoal e telefonia celular (2 ocorrências).

c) protagonismo e espaço "geográfico" do negro 
Podemos afirmar que em todo o período analisado se manteve a tendência de colocar o negro em segundo plano e/ou afastado do centro do anúncio. Da mesma forma, o negro raramente aparece sozinho ou em posição de igualdade com os personagens brancos.

Os números mostram que do total de 86 anúncios analisados, somente em 33 o negro aparece sozinho (sem dividir a cena com brancos). E destes, em 21 ele está ligado aos estereótipos do atleta, músico, trabalhador braçal ou carente social. Da mesma forma, o personagem negro aparece em segundo plano (ou em posição pouco privilegiada) em 41.

Devemos admitir que houve um crescimento na proporção de peças em que o negro aparece sozinho, subindo de 12\% em 1985 para 54\% em 1995, caindo fortemente para 28\% em 2005. Por outro lado, a proporção de anúncios no qual o negro “contracena” com brancos, mas aparece em segundo plano também subiu: de 13\% em 1985, para 53\% em 1995 e 61\% em 2005.

d) formas de representação

No item anterior nos referimos a alguns estereótipos sob os quais os personagens negros aparecem representados. De fato, nos pareceu essencial para este trabalho identificar e quantificar tais estereótipos, e foi o que fizemos tomando por base a bibliografia clássica sobre o assunto (Hasenbalg, d’Adesky, Couceiro de Lima) e nossa observação. Estabelecemos então 6 categorias que cobriram mais da metade do universo pesquisado: o trabalhador braçal ou pouco qualificado; o artista (músico, ator, dançarino); o atleta; a mulata; o africano (ou primitivo) e o carente social.

Do total de 86 peças da amostra, 53, ou seja, 62\% traziam o negro representado sob um dos estereótipos apontados acima. Mas se olharmos ano a ano perceberemos, apesar de certa oscilação, uma tendência de queda dentro do período.

Tabela 4 - Número de anúncios com negros estereotipados

\begin{tabular}{|c|c|c|c|}
\hline Ano & $\begin{array}{c}\text { Anúncios } \\
\text { com negros }\end{array}$ & $\begin{array}{c}\text { c/ negros } \\
\text { estereotipados }\end{array}$ & $\mathbf{\%}$ \\
\hline $\mathbf{1 9 8 5}$ & 8 & 6 & $75 \%$ \\
\hline $\mathbf{1 9 9 0}$ & 7 & 5 & $71 \%$ \\
\hline $\mathbf{1 9 9 5}$ & 13 & 11 & $85 \%$ \\
\hline $\mathbf{2 0 0 0}$ & 26 & 14 & $53 \%$ \\
\hline $\mathbf{2 0 0 5}$ & 32 & 14 & $43 \%$ \\
\hline Total & $\mathbf{8 6}$ & $\mathbf{5 3}$ & $\mathbf{6 2} \%$ \\
\hline
\end{tabular}


A queda no número de anúncios com negros estereotipados (ou “anúncios estereotipantes”) é indício de que com o passar do tempo o negro conquistou papéis diferentes dos que lhe foram historicamente atribuídos. No entanto, resta clara a forte permanência dos estereótipos clássicos, haja vista o percentual de 43\% em 2005.

Porém, o fato dos anúncios estereotipantes terem diminuído não significa necessariamente, que os anúncios “não-estereotipantes” contenham negros em papéis de prestígio social. Observando cuidadosamente esses anúncios não-estereotipantes, podemos notar certa "neutralização" da figura do negro, que não aparece sob estereótipos que o menosprezam, tampouco associado a papéis que denotem uma posição superior.

Tabela 5 - Anúncios estereotipantes (por categoria de estereótipo), valorizantes e neutros

\begin{tabular}{|c|c|c|c|c|c|c|c|c|c|}
\hline Ano & $\begin{array}{c}\text { Anúncios } \\
\text { com negros }\end{array}$ & $\begin{array}{c}\text { Trabalhador } \\
\text { Braçal }\end{array}$ & Artista & Atleta & Mulata & $\begin{array}{c}\text { Carente } \\
\text { social }\end{array}$ & Africano & Valorizado & Neutro \\
\hline $\mathbf{1 9 8 5}$ & 8 & 4 & 2 & - & - & - & - & 1 & 1 \\
\hline $\mathbf{1 9 9 0}$ & 7 & - & 1 & 1 & 1 & 1 & 1 & 1 & 1 \\
\hline $\mathbf{1 9 9 5}$ & 13 & 2 & 2 & 1 & 2 & 2 & 2 & 1 & 1 \\
\hline $\mathbf{2 0 0 0 *}$ & 26 & 3 & 4 & 6 & - & 2 & - & 4 & 8 \\
\hline $\mathbf{2 0 0 5} *$ & 32 & 1 & 4 & 6 & - & 4 & - & 2 & 16 \\
\hline Total & $\mathbf{8 6}$ & $\mathbf{1 0}$ & $\mathbf{1 3}$ & $\mathbf{1 4}$ & $\mathbf{3}$ & $\mathbf{9}$ & $\mathbf{3}$ & $\mathbf{9}$ & $\mathbf{2 7}$ \\
\hline
\end{tabular}

*nesse ano houve caso de dois negros com estereótipos diferentes num mesmo anúncio

A tabela mostra que historicamente os negros são mais comumente representados como, atleta (16\%), artista (15\%), trabalhador braçal (11\%) e carente social (10\%). A mulata e o africano (3,5\% cada) aparecem em menor escala, mas sua presença não pode ser ignorada. Já os negros valorizados correspondem a 10\% do total, frente a 31\% de anúncios onde sua imagem é neutra.

Tabela 6 - Percentual de anúncios com negros estereotipados, valorizados e neutros

\begin{tabular}{|c|c|c|c|}
\hline Ano & estereotipados & Valorizados & Neutros \\
\hline $\mathbf{1 9 8 5}$ & $75 \%$ & $12 \%$ & $12 \%$ \\
\hline $\mathbf{1 9 9 0}$ & $71 \%$ & $14 \%$ & $14 \%$ \\
\hline $\mathbf{1 9 9 5}$ & $85 \%$ & $7 \%$ & $7 \%$ \\
\hline $\mathbf{2 0 0 0} *$ & $57 \%$ & $15 \%$ & $30 \%$ \\
\hline $\mathbf{2 0 0 5} *$ & $43 \%$ & $6 \%$ & $50 \%$ \\
\hline
\end{tabular}

* nesse ano houve caso de dois negros com estereótipos diferentes num mesmo anúncio 
O número de anúncios com negros valorizados e neutros nos anos de 1985, 1990 e 1995 podem ser considerado pequeno se comparado ao número de anúncios estereotipantes do mesmo período. Entretanto, queremos chamar a atenção para o crescimento dessas cifras a partir do ano 2000, e não só isso, queremos apontar para o fato dos anúncios valorizantes terem se mantido praticamente estáveis enquanto o número de anúncios neutros cresceu rapidamente. Isso nos leva a crer que não se pode falar ainda em valorização da imagem do negro, mas sim em neutralização da imagem do negro.

Naturalmente, categorias como estereotipantes, valorizantes e neutros são categorias subjetivas e abertas à discussão. Nem tudo aquilo que consideramos neutro ou valorizante, por exemplo, será visto da mesma forma fora do contexto desse trabalho. Assim, a partir do próximo tópico, buscaremos analisar sob uma ótica qualitativa os estereótipos até agora apontados e discutir tais categorias.

\section{4 - Aspectos qualitativos}

Segundo Lopes, a fase de interpretação é a etapa na qual “a pesquisa atinge a condição própria da cientificidade. É a fase que envolve a teorização dos dados empíricos dentro da perspectiva teórica adotada no início da pesquisa”. Se a análise descritiva é aquela que “visa à reconstrução da realidade do fenômeno por meio de operações técnico-analíticas que convertem os dados de fato em dados científicos”, a análise interpretativa tem por objetivo explicar o "fenômeno mediante operações lógicas de síntese e de amplificação levando a análise a um nível superior de abstração e de generalização” (LOPES, 2005, p.151-152).

Sendo assim, convém apontar que o nosso referencial teórico não é a semiótica, tendo em vista que o foco da pesquisa não está propriamente na análise de signos e significados, mas sim nas formas de representação do negro nos anúncios. Dessa forma, buscamos suporte na Antropologia Visual, mais especificamente na obra Antropologia da Comunicação Visual, do italiano Massimo Canevacci.

Canevacci coloca que um dos níveis da abordagem antropológica da comunicação visual é a “análise dos produtos da comunicação visual reprodutível na sua totalidade, isto é, fenômeno global da cultura visual, (...) seja para compreender seus modos simbólicos, seja para reforçar a referida pesquisa numa relação interativa” (CANEVACCI, 1990, p.11).

Essa comunicação visual reprodutível, termo que engloba um conjunto bastante amplo dos meios de comunicação de massa, Canevacci define como sendo um "conjunto orgânico caracterizado pela reprodutibilidade técnica que emite signos, símbolos e sinais com uma 
relação assimétrica entre emitente e destinatário”, já que para o autor “a comunicação viaja numa única direção” (CANEVACCI, 1990, p.12).

Contudo, Canevacci não vê a comunicação visual reprodutível (CVR como denomina na maior parte da obra) como instrumento que impõe, pura e simplesmente, hábitos e modelos. O autor argumenta que os símbolos e signos emitidos pela CVR "sofrem uma tradução polissêmica nos comportamentos cotidianos dos espectadores que selecionam ‘segundo seus próprios’ critérios, os vários códigos (...)”. Assim, o “total, compreendidas as possíveis combinações” é que seria repetido mimeticamente, fundando grande parte da cultura contemporânea” (CANEVACCI, 1990, p.13).

É nesse sentido que Canevacci afirma: “A difusão da comunicação visual modifica a natureza da reprodução das idéias”. Se no século XVIII a ideologia - e não vamos entrar aqui na discussão sobre o que é ideologia - propunha suas idéias e valores como universais, mascarando os interesses de classe, gênero, raça e nação atrás do poder da "objetividade científico-naturalística” hoje, com a CVR, a ideologia "falaria” espontaneamente "através de um acervo de mensagens indiferentes e até contraditórias entre si, nas quais se exalta indireta e silenciosamente o triunfo do Ocidente” (CANEVACCI, 1990, p.13-14).

“Em síntese”, conclui o autor, “a imagem visual faz-se visão do mundo sem necessidade de mediações externas e explícitas, mas com plena e espontânea autonomia” (CANEVACCI, 1990, p.14).

Dentro desse contexto a publicidade seria um dos "lugares mais lúcidos" de “divulgação didática” exatamente porque consegue representar e sintetizar "as tendências culturais e comportamentais mais sutis” (CANEVACCI, 1990, p.14).

Assim, numa sociedade como a brasileira, na qual as elites vêem há tempos construindo um discurso que utiliza a mestiçagem como forma de apaziguar os conflitos raciais, a CVR (e a publicidade em especial) tenderia a reproduzir a “ideologia” dos grupos dominantes ao escamotear e marginar o negro.

Em toda estrutura codificada da codificação, ainda que historicamente determinada, permanecem traços do domínio ideológico das classes hegemônicas atuais, mas também das passadas (...). Tudo isso implica um extravasamento de sinais, mensagens, modelos do hegemônico ao subalterno, cujo veículo aparentemente neutro são esses códigos. Enfim, essa dialética perversa tende, de um lado, a perpetuar a sobrevivência dos tradicionais e, de outro, a desprivar as projetualidades utópicas de toda carga subversiva que as mutações das condições histórico-culturais permitem (CANENACCI, 1990, p.182-183).

Na visão do autor, as sociedades de um modo geral tenderam a modificar a maneira com a qual enfrentam a diversidade. No passado, o outro "era esmagado, reprimido, 
eliminado e submetido ao colonialismo (...). Mais recentemente, com o reconhecimento dos “direitos formais à diversidade” a prática cotidiana teria se transformado em algo como “respeitar os outros permanecendo nós mesmos” (CANEVACCI, 1990, p.14).

O resultado disso, afirma Canevacci, foi “indiferença, hostilidade latente, respeito 'guetizante', quando não declarado racismo; ou, ao contrário, estetismos exóticos, turistilizados (...)”.

Acreditamos que vários desses fenômenos apontados por Canevacci possam ser encontrados na mídia e na publicidade brasileira, e são exatamente esses pontos que buscaremos identificar em nossa análise. Enquanto a indiferença está evidenciada na invisibilidade imposta ao negro, a “estetização” e a "getização” podem ser percebidas nas formas de representação que estabelecem, com base ainda em resquícios da visão oitocentista a respeito do escravo, lugares próprios para o negro brasileiro.

\subsection{1 - O trabalhador braçal}

O trabalhador braçal, ou trabalhador não qualificado, é uma das formas mais comuns de representação do negro dentro do universo pesquisado, e talvez seja aquela que remeta mais diretamente ao período escravocrata. A este estereótipo associa-se não apenas a imagem do operário, mas também do pescador, da cozinheira, do vendedor ou de qualquer outra profissão de menor remuneração ou considerada de pouco prestígio.

Nos anúncios ligados a essa categoria o negro, de um modo geral, aparece uniformizado (ou caracterizado por instrumentos e roupas específicas da profissão), em pleno exercício de suas atividades e muitas vezes divide a cena com indivíduos brancos que exercem alguma relação hierárquica para com ele.

Os dois primeiros anúncios referem-se à imagem do operário. Podemos ver que neles os personagens negros aparecem em seus locais de trabalho, uniformizados, de capacete e, em um deles, em plena atividade.

No primeiro anúncio, da Companhia Vale do Rio Doce (à época uma estatal), vemos um homem negro de macacão escuro ao lado de um homem branco de camisa clara. Os dois estão de capacete, mas a diferença na vestimenta deixa claro que o homem branco é o chefe e o homem negro o operário. Além disso, a boca semi-aberta do homem branco e a boca fechada do homem negro nos transmite a impressão que o primeiro está falando enquanto o segundo escuta passivamente. Podemos perceber também a existência de uma oposição entre o claro (homem branco de camisa branca) e o escuro (homem negro de roupa escura), e uma certa centralidade do elemento claro na foto. 


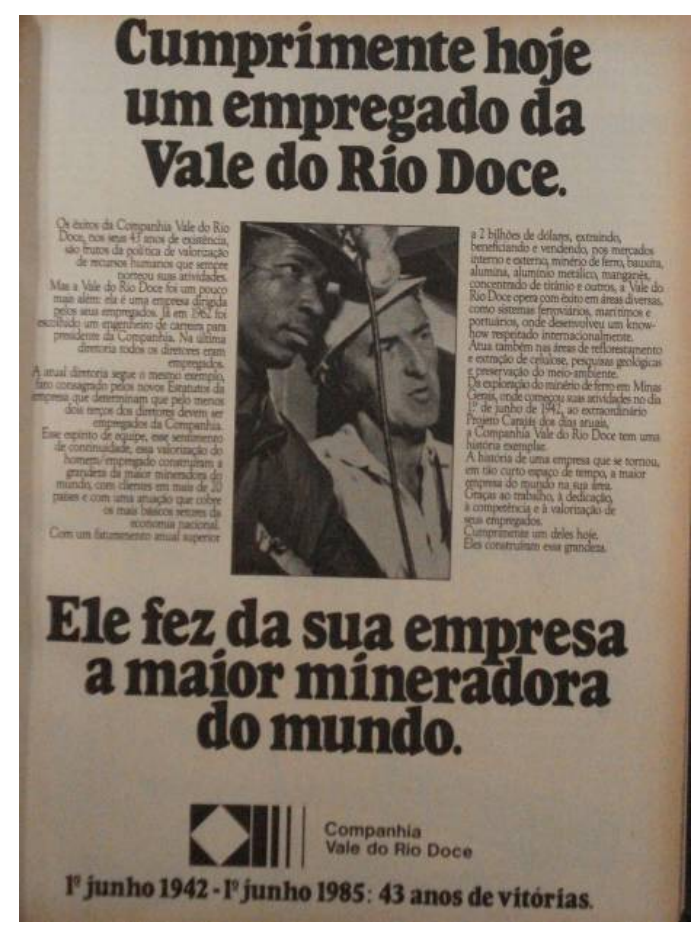

(Veja, 1985)

Já no segundo, o homem negro não aparece trabalhando, mas está de uniforme e equipamentos de proteção. Nas outras fotos mostradas no anúncio encontramos diversas pessoas brancas (e dois negros) trabalhando ou se divertindo, mas em apenas uma aparece um branco com uniforme de operário. Mesmo assim, esse branco uniformizado está sem os equipamentos de proteção e sorrindo, o que denota momento de descontração, isso sem contar o fato de ele estar numa foto proporcionalmente maior que a do negro, e que em seu uniforme aparece visivelmente a logomarca da empresa, coisa que no uniforme do negro não é possível identificar.

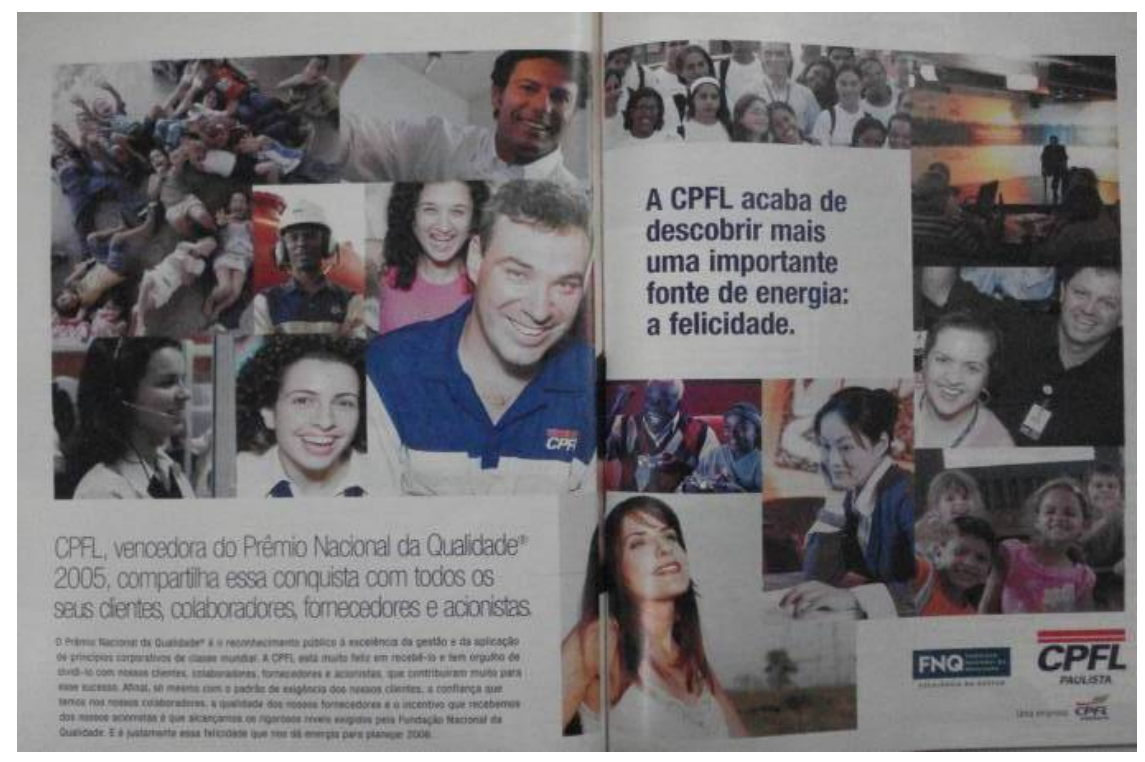

(Veja, 2005) 
Nos três anúncios seguintes o negro não é propriamente trabalhador braçal, mas encontra-se exercendo atividades que não requerem qualificação específica e que oferecem menor potencial de renda.

A peça publicitária da Lufthansa nos mostra uma jovem uniformizada atrás de um balcão atendendo a um homem branco de terno. A jovem tem alguns traços fenotípicos que “denunciam” sua ascendência negra, mas ao mesmo tempo tem a pele um pouco mais clara e os cabelos lisos. De maneira parecida à do primeiro anúncio, a negra uniformizada parece escutar ao branco sem uniforme, mas aqui numa condição diferente: ao invés de uma relação chefe/subordinado temos uma relação, também hierárquica, entre o consumidor e o funcionário prestador de serviço.

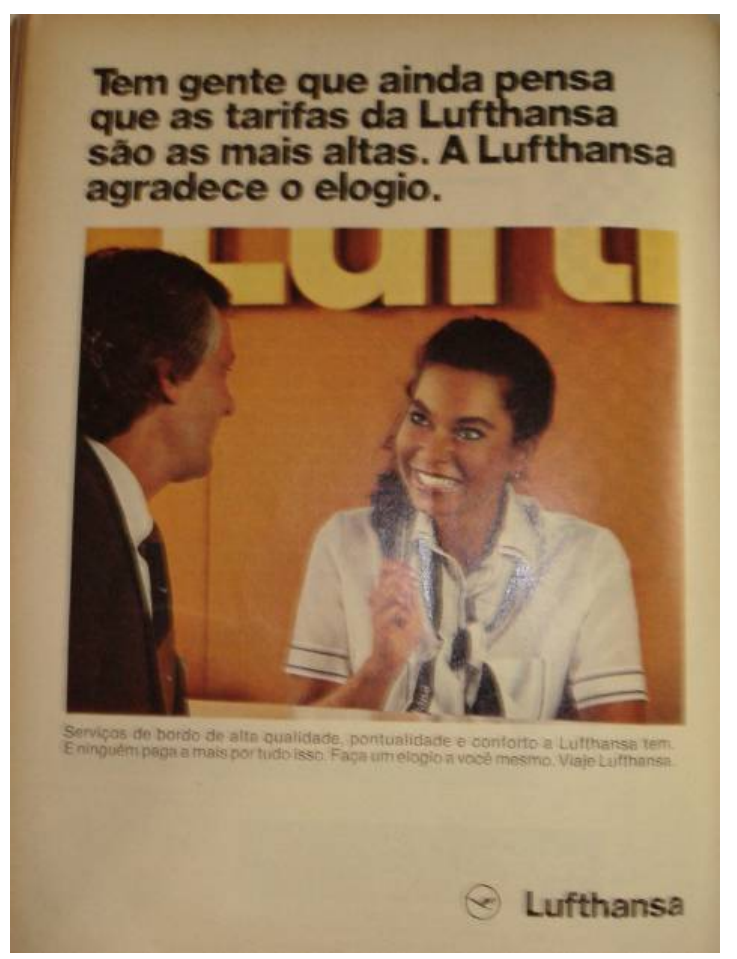

(Veja, 1985)

Na peça da Bahiatursa, empresa de turismo do estado da Bahia, vemos típica "baiana do acarajé”, trajada com vestido branco, brincos e colares, carregando seus utensílios na cabeça e protegendo a todos da chuva num ponto de ônibus.

A clássica imagem da quituteira já nos remete à idéia de um trabalhador não qualificado, que produz e vende suas mercadorias de forma precária em plena rua. E o fato da personagem estar sob a chuva, num ponto de ônibus é outra referência à sua condição social. 


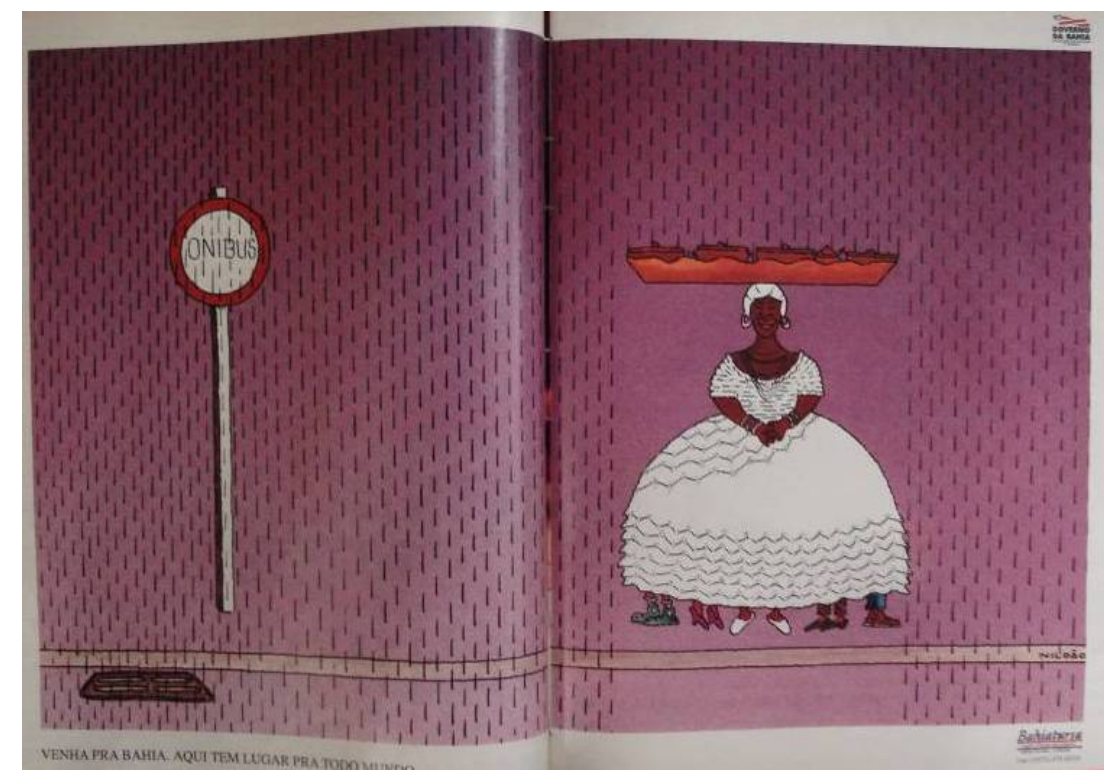

(Veja, 1995)

O próximo anúncio é uma campanha do Ministério do Trabalho e Emprego sobre a RAIS (Relação Anual de Informações Sociais). Nele, aparacem os crachás com fotos de quatro funcionários de uma empresa fictícia: duas mulheres brancas, e dois homens, um branco e um negro. Nos crachás de cada um constam além do nome, o cargo que o funcionário exerce na empresa. Uma das mulheres é gerente, a outra é secretária e no caso do homem branco não há referencia ao seu cargo mas sim à sua seção: departamento financeiro. Dos quatro, o homem negro é aquele que supostamente tem o nível hierárquico mais baixo: assistente de vendas. Ademais, é importante notar que o rapaz negro é o único que aparece vestido apenas com roupas escuras, e que na disposição das imagens no anúncio ele se encontra abaixo dos funcionários brancos.

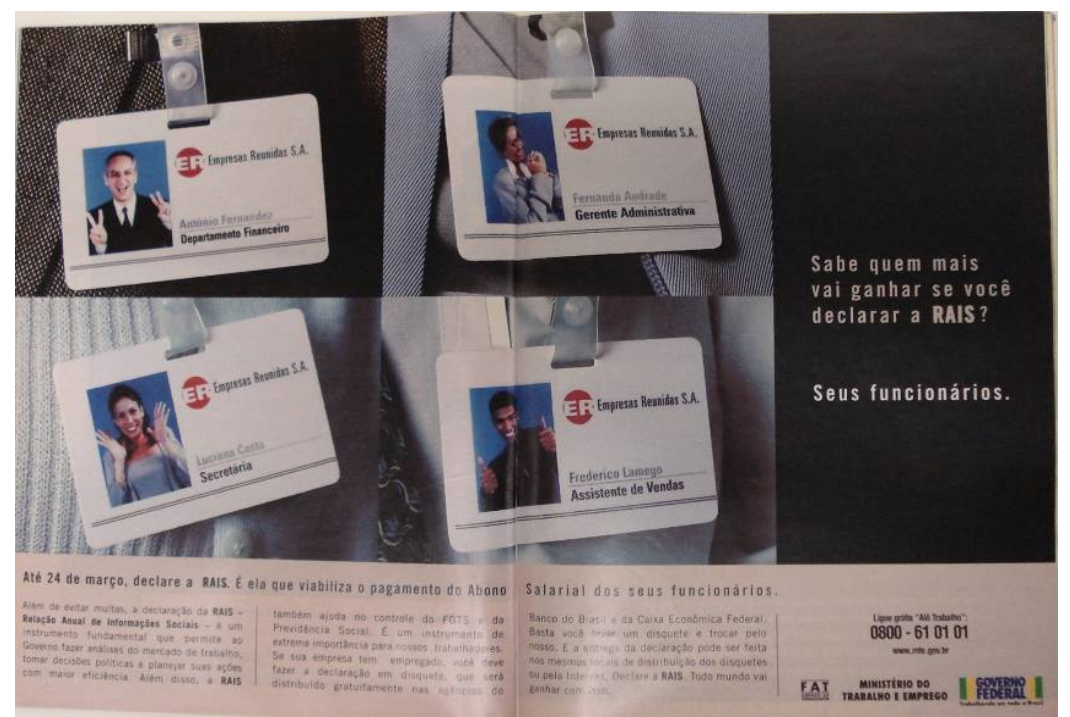

(Veja, 2000) 
Podemos perceber que nesses anúncios, assim como em todos os que estão ligados a essa categoria, fica evidente o distanciamento e a separação econômica e simbólica entre a classe dominante branca e a classe trabalhadora negra, em uma relação similar ao sistema escravocrata (CORRÊA, 2006, p.80).

Durante o período em que vigorou a escravidão, os trabalhos considerados humilhantes, insalubres ou que exigiam força física eram reservados aos negros, considerados “peças” mais apropriadas a esse tipo de serviço. Essa condição, associada a um processo de exclusão que impediu o negro de competir com igualdade no mercado de trabalho no período pós-abolição acabou por reproduzir e naturalizar a situação e a imagem do negro como trabalhador braçal.

Isso fica evidente quando observamos anúncios em que o branco fala (ou parece falar) enquanto o negro escuta - a exemplo dos anúncios da Companhia Vale do Rio Doce ou da Lufthansa - quando vemos anúncios em que aparece um negro trabalhando e outras pessoas se divertindo; ou ainda quando a negra quituteira (que por si só já é uma imagem do período escravista) toma chuva para proteger a outros embaixo de suas saias.

\subsection{2 - O atleta}

O atleta é o estereótipo mais comum encontrado em nossa amostra e está, assim como o trabalhador braçal, ligado à questão do vigor físico. A imagem do escravo forte (muitas vezes comparado a um animal), trabalhador das lavouras e das minas, serviu também para fazer do negro um ser mais “adaptado” aos esportes.

Nesses anúncios, o personagem negro é quase sempre um jogador de futebol, está uniformizado, em campo e normalmente vestindo uma camisa da seleção brasileira. Outra possibilidade, ainda ligada ao futebol, é que o negro apareça como torcedor. Uma terceira imagem, bastante freqüente inclusive, é a do praticante de atletismo, quase sempre um negro musculoso também uniformizado.

O curioso das peças publicitárias que compõe essa categoria é que apesar do Brasil ser um país reconhecido por seus jogadores de futebol negros, e apesar do futebol ser um esporte “das massas” populares, ainda sim, em muitos anúncios o negro é minoria dos atletas ou dos torcedores.

O primeiro anúncio que vemos é da Rede Bandeirantes de Televisão (a Band), que durante muito tempo se intitulou "o canal do esporte”. A peça anuncia sua programação de jornalismo, esportes e filmes, e coloca duas imagens para ilustrar o anúncio: o jornalista 
(branco) Chico Pinheiro, hoje na Rede Globo, e um lance de um jogo de futebol, no qual um atleta negro e outro branco disputam a bola.

De um lado então está um homem branco, de terno e gravata, com uma profissão prestigiada e tida como séria; e de outro, jogadores de futebol (um branco e um negro), profissão que não requer formação acadêmica, confere status somente a poucos (a grande maioria dos jogadores de futebol não jogam no exterior e não têm salários milionários) e que muitos consideram como diversão.

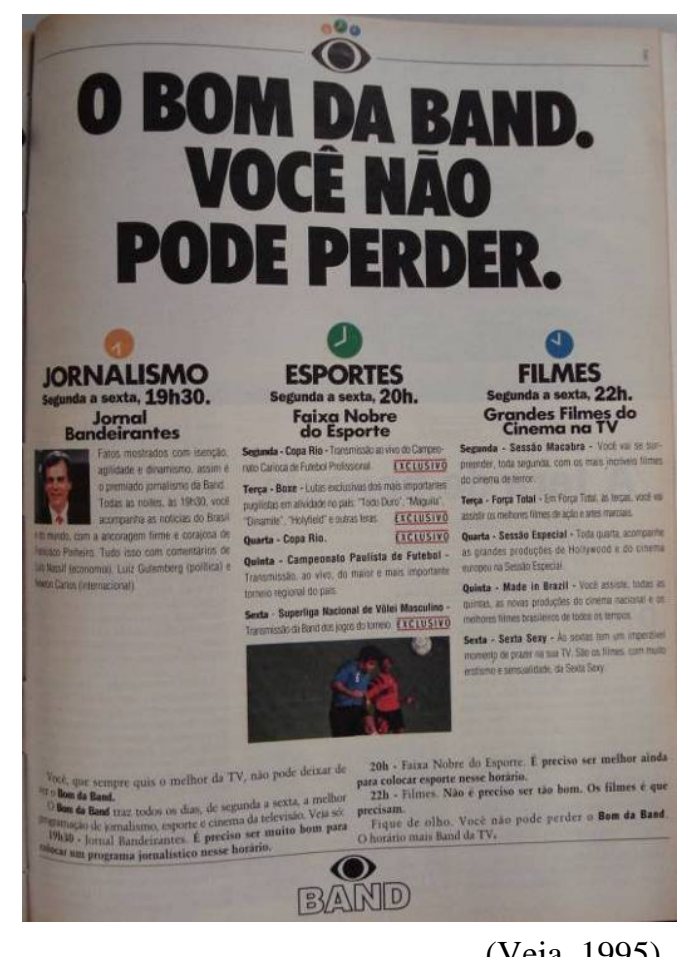

(Veja, 1995)

No segundo anúncio, da operadora de telefonia fixa Intelig, encontramos sete fotos de pessoas famosas (julgamos interessante inserir aqui só as que comentaríamos), como Joãozinho Trinta, Gisele Bündchen e Vinícius de Oliveira. Entre os famosos, dois atletas de renome internacional: o nadador Fernando Scherer, atleta olímpico, campeão mundial, campeão pan-americano; e o goleiro Dida, à época jogador do Corinthians, da seleção brasileira, também campeão do mundo.Os dois atletas são igualmente famosos, e provavelmente a maior parte das pessoas os reconheceria apenas por seus rostos. No entanto, é interessante reparar que o goleiro Dida foi fotografado com suas luvas, uma clara referência ao esporte que pratica, enquanto Fernando Scherer aparece sem nenhum tipo de referência à sua atividade. Aqui, vemos que mesmo sem prejuízo ao entendimento do anúncio ou ao reconhecimento dos atletas, faz-se questão de "marcar" o atleta negro como um jogador de futebol. 

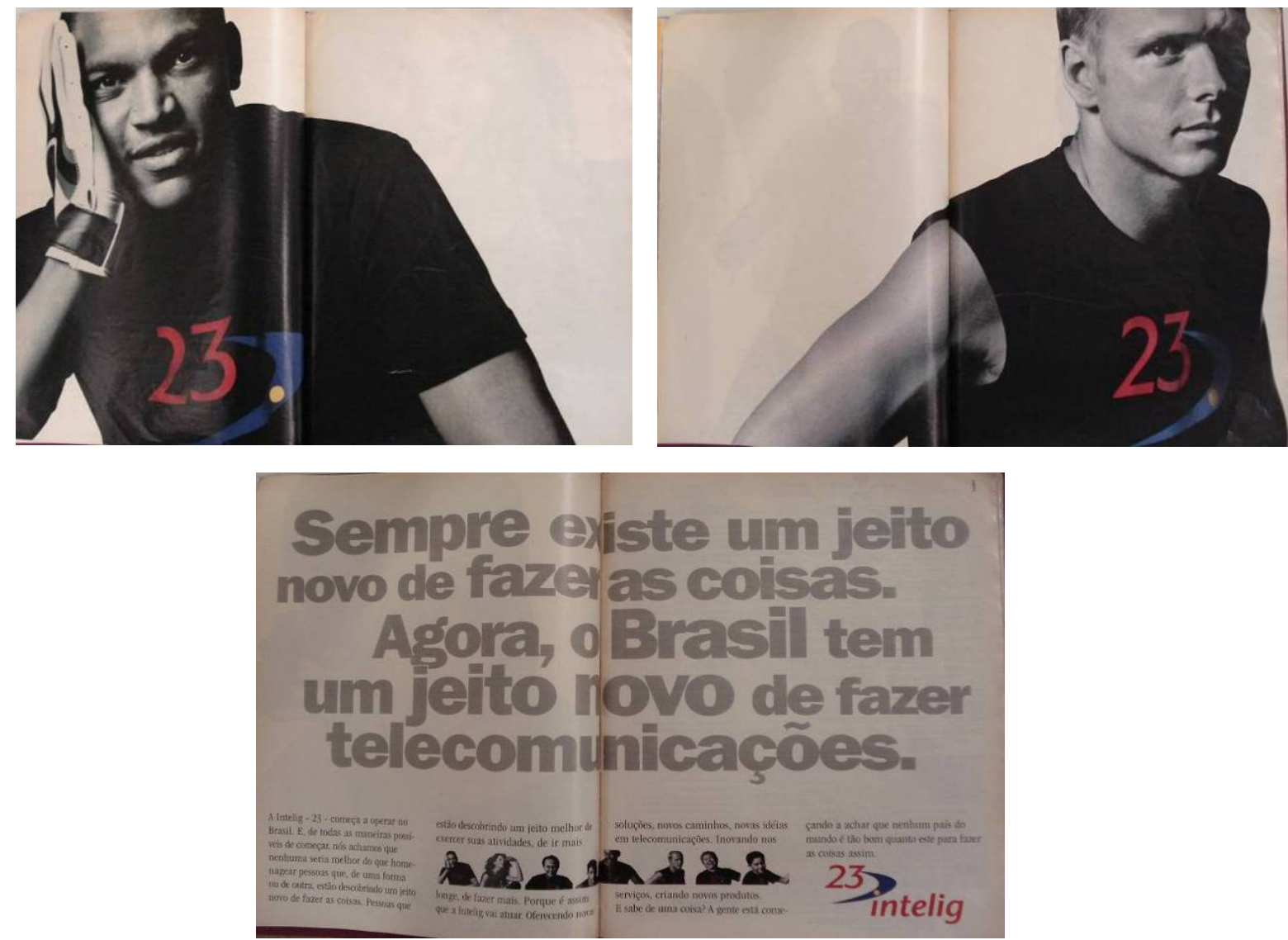

(Veja, 2000)

A terceira peça publicitária é da fabricante de produtos esportivos, e patrocinadora do Comitê Olímpico Brasileiro, Olympikus. Nela aparece o corredor Claudinei Quirino, também atleta olímpico e campeão mundial. O atleta aparece uniformizado, ostentando a logomarca da empresa, e numa posição característica do esporte. É interessante notar que apesar de famoso, Quirino não tem seu rosto mostrado no anúncio (sua identificação é feita por uma legenda), mas sobressaem seus músculos e o logotipo da empresa.

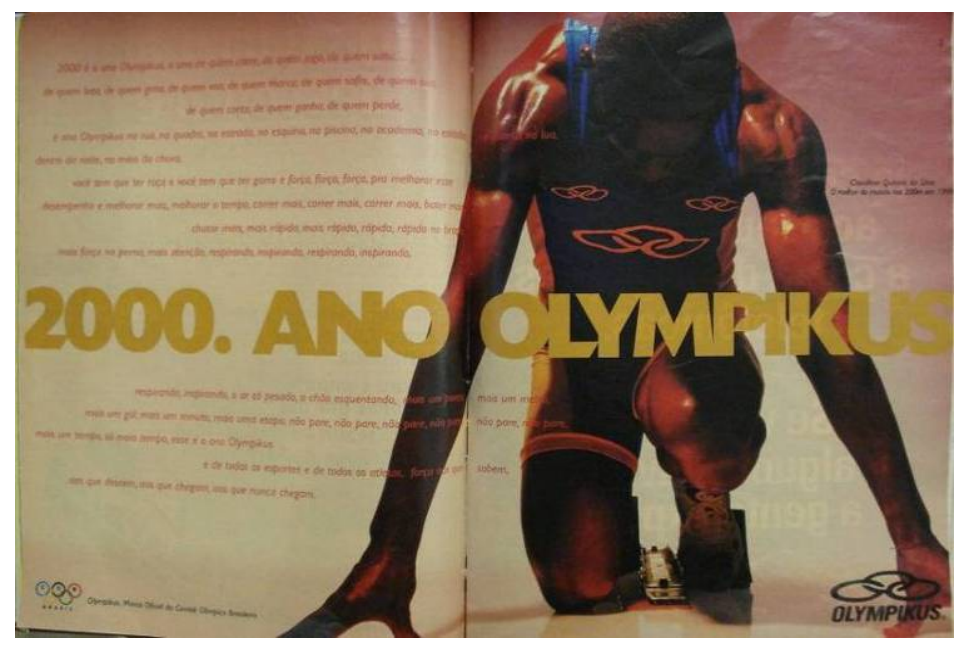

(Veja, 2000) 
Voltamos ao futebol no anúncio seguinte, mas ao invés de atletas, o que vemos são torcedores. Nesse anúncio da operadora de telefonia fixa Embratel, temos um cenário que alude a um estádio, e uma torcida que, pela cor do uniforme e pelo título da peça, “vibra” a favor da seleção brasileira de futebol. A torcida é composta por mais de dez pessoas, sendo apenas uma negra, que se encontra em segundo plano, e sem o número 21 (número da operadora) estampado na camiseta.

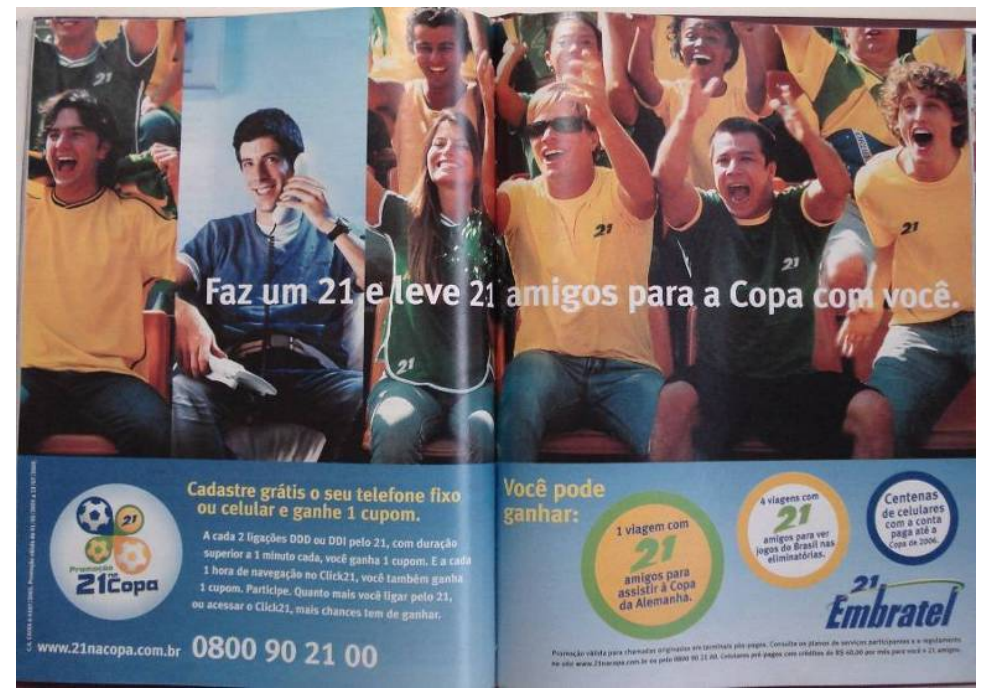

(Veja, 2005)

Nesse anúncio queremos ilustrar a questão que levantamos há pouco sobre os jogadores negros de futebol. Aqui, vemos quatro jogadores de futebol provavelmente comemorando um gol. Podemos ver em primeiro plano um jogador branco (que parece ter marcado o gol) e atrás deste mais três, dois brancos e um negro. O jogador negro tem a camisa de número 10, talvez uma referência a Pelé, e encontra-se posicionado quase "fora” do anúncio, parecendo estar ali apenas para “compor” o cenário de um campo de futebol.

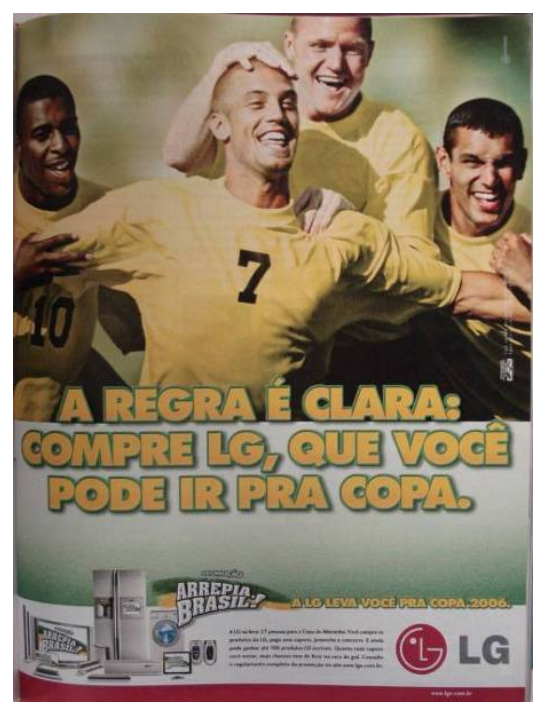

(Veja, 2005) 
Apesar dos diferentes produtos, dos diferentes cenários e da diferença cronológica entre os anúncios até agora apresentados, algo que todos têm em comum (e isso é presente em alguns outros não mostrados) é a referência direta ao Brasil. Seja na camisa dos atletas, no uniforme dos corredores ou no texto do anúncio, existe, de maneira ostensiva, uma associação entre o negro, o esporte e a identidade nacional.

Convém ainda apresentar outros dois anúncios, que diferem do binômio campo de futebol/pista de atletismo, mas não rompem totalmente com o estereótipo do atleta. No primeiro (à esquerda), temos um anúncio da Lufthansa no qual o protagonista é o ex-jogador de futebol Edson Arantes do Nascimento, o Pelé. De fato, neste caso, o cenário não é um estádio, tampouco o garoto-propaganda aparece uniformizado, contudo, a fama e a proeminência internacional adquiridas por Pelé - o atleta do século XX - em outras esferas (política, econômica, assistencial) advêm de sua carreira futebolística. Assim, apesar da referência não ser direta, a simples presença de Pelé, ou do Edson (como o texto do anúncio coloca), remeteria quase que automaticamente ao futebol.

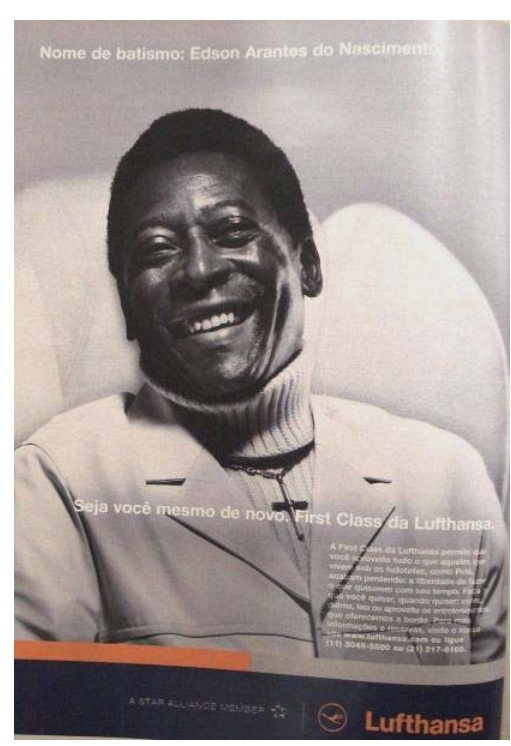

(Veja, 2000)

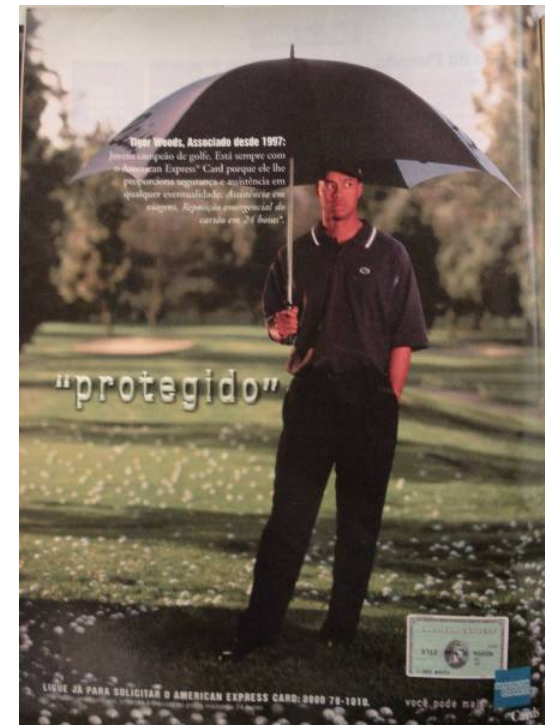

(Veja, 2000)

O segundo anúncio (à direita) apresentado como “exceção” é do cartão de crédito American Express, no qual figura o golfista Tiger Woods. Nessa peça, que aparentemente foi “importada” dos EUA, faz-se referência direta ao golfe, um esporte considerado elitista, mas que nem por isso deixa de ser considerado esporte. Além disso, Woods é colocado num campo de jogo, assim como se colocam os corredores na pista de atletismo e os jogadores de futebol no estádio, e, ao contrário do que ocorre com o jogador de futebol Dida em anúncio da Intelig apresentado acima, o golfista estadunidense aparece justamente sem o equipamento típico do golfe, o taco. 
É possível notar, portanto, duas formas de utilização do negro atleta: por um lado, o negro é utilizado para compor uma cena na qual a temática é o esporte; e por outro, atletas de renome têm seu alto desempenho associado à imagem de certos produtos.

\subsection{3 - O artista}

O estereótipo do artista é outra forma recorrente de representação do negro, e assim como o estereotipo do atleta, estaria ligado ao que Hasenbalg chama de "canais de mobilidade considerados legítimos para o negro” (HASENBALG, 1988, p.184).

Segundo o autor, as atividades ligadas à diversão (jogadores de futebol, artistas, cantores e compositores de música popular) seriam as únicas vistas como válidas para que o negro ascenda socialmente (HASENBALG, 1988, p.184), de modo que nesses espaços, a presença e a circulação de negros seriam vistas como normais e até mesmo esperadas.

Nesse sentido, da mesma forma que nos deparamos com esportistas de sucesso em anúncios, é igualmente comum encontrarmos peças publicitárias nas quais artistas negros famosos "emprestam" seu prestígio e seu carisma a determinadas campanhas, ou ainda divulgando a si mesmos (ou seus próprios produtos).

A atriz Zezé Mota, em anúncio do chopp Brahma, aparece ao lado de outros artistas igualmente famosos dando o seu aval a respeito da qualidade do referido produto. Caberiam aqui duas observações pontuais: uma é a de que na disposição das imagens, a garrafa aparece como um sexto “artista” no anúncio. Outra diz respeito à vinculação da imagem do negro ao campo da diversão. Além de se colocar uma artista negra num anúncio de bebida (o que por si só sugeriria um vínculo entre bebida, negro e divertimento), a peça publicitária divide espaço justamente com uma reportagem sobre esportes.

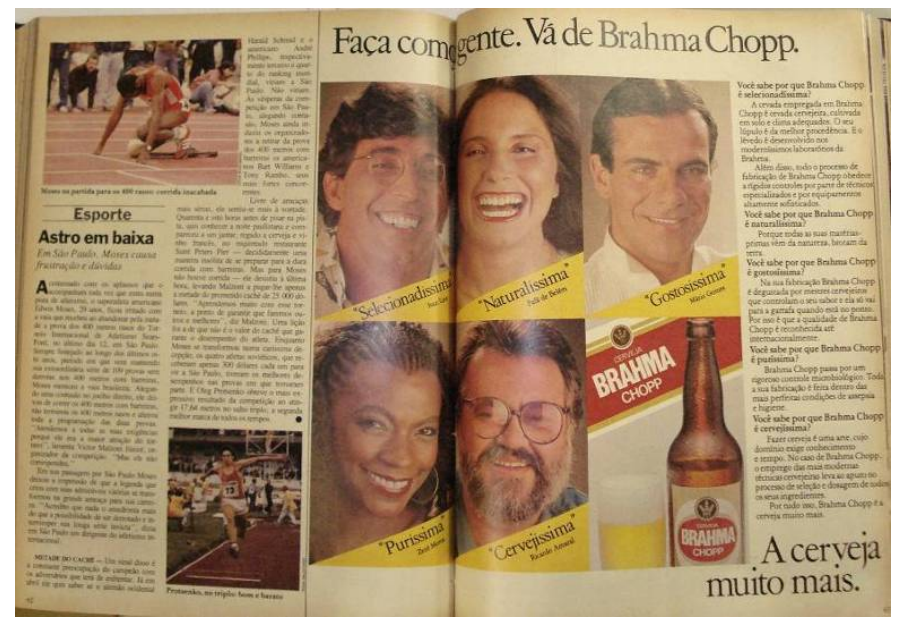

(Veja, 1985) 
Os dois anúncios seguintes nos mostram artistas famosos (de diferentes vertentes e gerações) “emprestando” sua imagem a campanhas publicitárias. Gilberto Gil, cantor e compositor, aparece em anúncio do Serviço de Apoio às Micro e Pequenas Empresas (SEBRAE) cujo texto faz uma associação entre à sua canção Expresso 2222 (também nome de seu bloco de carnaval) e seu programa Brasil Empreendedor que teria início no ano 2000, enquanto os cantores Carlinhos Brown e Falcão (do grupo Rappa) aparecem em anúncio da cerveja Skol.

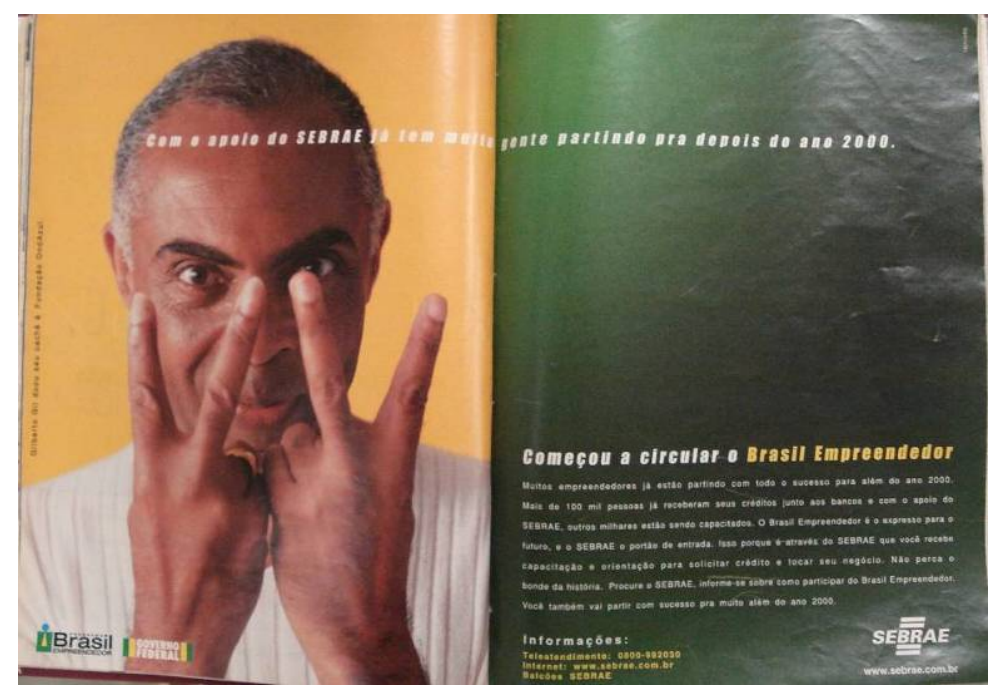

(Veja, 2000)

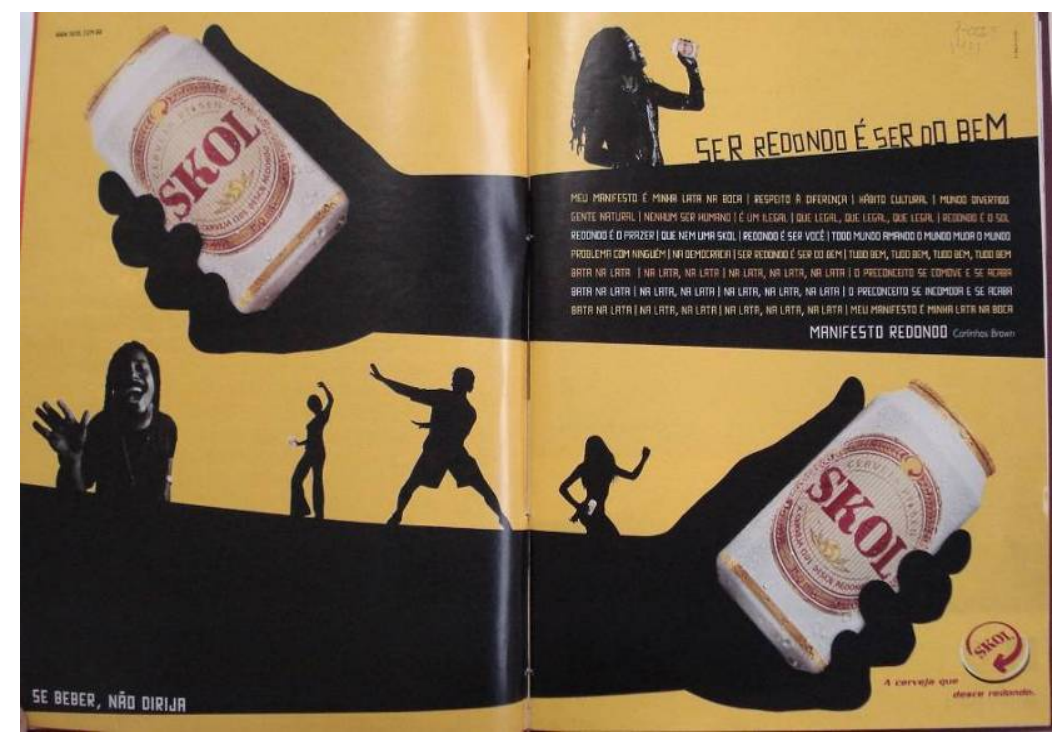

(Veja, 2005)

Nesse segundo anúncio, além da associação negro/diversão, está presente a imagem do negro exótico. Ambos os cantores aparecem no anúncio com dreadlocks (popularmente 
conhecido como “cabelo rastafári”) e utilizando acessórios pouco convencionais à moda tida como padrão.

Outro ponto interessante a ser destacado diz respeito ao texto inserido no anúncio ${ }^{40}$, intitulado Manifesto redondo (em alusão ao slogan da marca: “desce redondo”) e de autoria atribuída a Carlinhos Brown. Transcrevemos aqui integralmente (grifos nossos):

Meu manifesto é minha lata na boca | Respeito à diferença | Hábito cultural
| Mundo divertido | Gente natural | Nenhum ser humano | É um ilegal | Que
legal, que legal que legal | Redondo é o sol | Redondo é o prazer | Que nem
uma Skol | Redondo é ser você | Todo mundo amando o mundo muda o
mundo | Problema com ninguém | Na democracia | Ser redondo é ser do bem
| Tudo bem, tudo bem, tudo bem, tudo bem | Bata na lata | Na lata, na lata |
Na lata, na lata, na lata | O preconceito se comove e se acaba | Bata na lata
| Na lata, na lata | Na lata, na lata, na lata | O preconceito se incomoda e se
acaba | Bata na lata | Na lata, na lata | Na lata, na lata, na lata | Meu
manifesto é minha lata na boca.

Não queremos aqui enveredar por uma análise minuciosa do "manifesto”, no entanto, já numa primeira leitura, percebemos que o anúncio traz um discurso em prol da democracia, da igualdade e do respeito às diferenças. No entanto, toda essa liberdade aparece de alguma forma vinculada ao consumo da bebida ("meu manifesto é minha lata na boca”, "Redondo é o prazer | Que nem uma Skol | Redondo é ser você”), e à performance musical indicada pela recorrência do imperativo "bata na lata”, uma expressão popular que se refere ao ato de tocar instrumentos de percussão. Em outras palavras, o caminho para o fim do preconceito seria "bater na lata” e tomar a referida cerveja, o que por si só seria um contra-senso, uma vez que reiteraria imagens que remontam ao século XIX, como o negro vadio ou o negro bêbado e degenerado.

Já no anúncio do filme Meu tio matou um cara (Jorge Furtado, Brasil, 2005), produção da Globo Filmes, os atores Lázaro Ramos (ao centro) e Darlan Cunha aparecem num anúncio de divulgação da película. O protagonismo no filme garantiu a Ramos um papel de destaque no anúncio, fato que não ocorre do mesmo modo com Cunha: o ator aparece ao lado direito do título da obra juntamente com a atriz Débora Secco, e ambos encontram-se no extremo do anúncio. Mais para o centro da página estão outros dois atores brancos (Renan Goelli e Sophia Reis), que apesar de aparecerem atrás de Ramos, têm posição privilegiada em relação à Cunha.

\footnotetext{
${ }^{40}$ Não é objetivo desse trabalho analisar os textos inseridos nos anúncios, contudo, em alguns casos, faz-se necessário tal procedimento afim de melhor demonstrar nossas hipóteses. O mesmo pode ser dito com relação à observação pouco anterior a respeito da colocação de um anúncio juntamente com uma reportagem sobre esportes.
} 


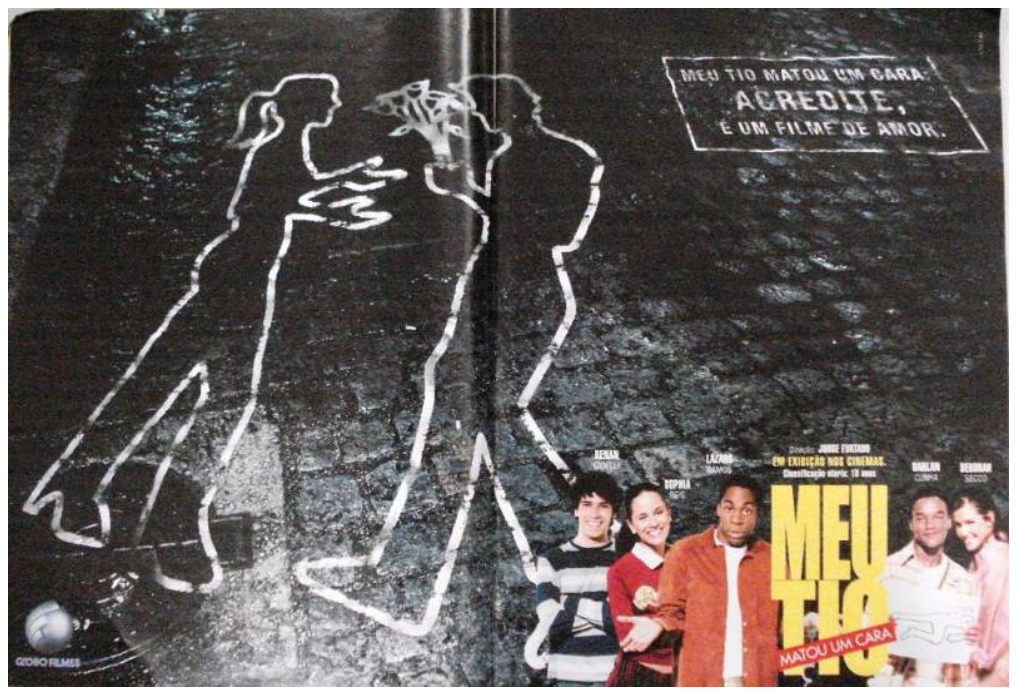

(Veja, 2005)

O anúncio abaixo, que também parece não ter sido produzido no Brasil, difere um pouco dos demais exatamente por não trazer um artista famoso, mas sim uma referência à música. A fábrica de canetas Parker, ao lançar sua linha Sonnet (soneto), busca em sua campanha fazer uma analogia entre a sofisticação que se atribui ao Jazz e a qualidade de seu produto, ou, indo um pouco mais longe, uma ligação entre o nome da empresa e do músico estadunidense Charlie "Bird” Parker, tido como um dos melhores instrumentistas de todos os tempos ${ }^{41}$.

Independente da intenção do publicitário (que teria aqui trocado o instrumento, já que Parker era saxofonista e o que aparece no anúncio é um trompete), o que interessa destacar nesse caso é o vínculo que parece se estabelecer entre a performance do músico (protagonista do anúncio) e a performance da caneta: “Nascido para performance. Como uma Parker”.

Mais do que isso, a frase "nascido para performance” sugere o talento para a música como uma habilidade inata e, portanto, natural, o que nos remeteria ao século XIX - período no qual as teorias

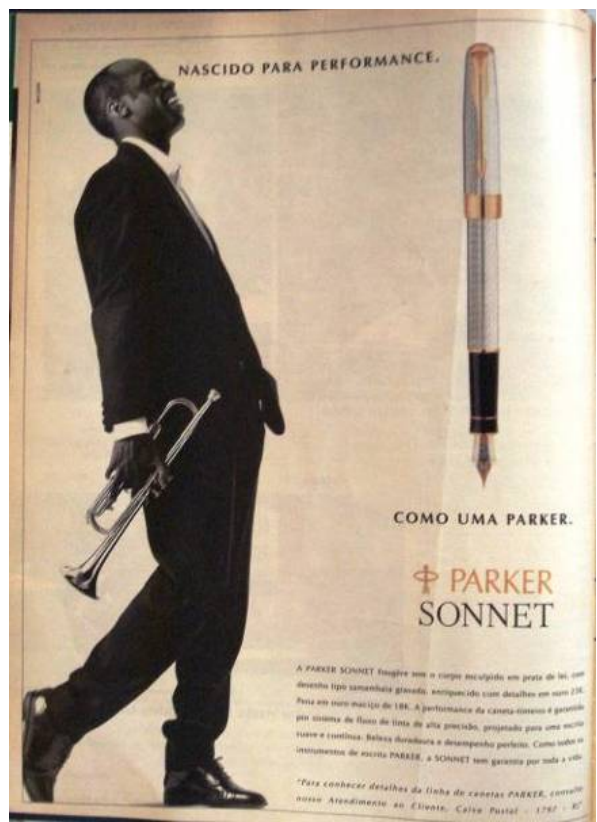

(Veja, 1995) científicas buscavam tratar das habilidades próprias da natureza de cada raça.

De fato, se voltarmos ao século XIX perceberemos que, de certa forma, as habilidades artísticas e/ou musicais dos escravos negros (principalmente urbanos e domésticos) era algo

\footnotetext{
${ }^{41}$ http://jazz.folha.com.br/musicos/04/
} 
que despertava a atenção dos seus senhores, a ponto de serem indicadas, por exemplo, nos anúncios de fuga:

Juiz de Fora, Escravo fugido: Acha-se fugido desde $10^{\circ}$ de março do corrente, o escravo Theodoro pardo, baixo, cabellos corridos e de boa figura (...) entende do offício de carpinteiro, sabe lidar com máquinas de corte, lê números e faz conta de memória, sabe música, canta e toca flauta e violão e leva-o corpo só roupa de serviço... (Correio Paulistano, 06/05/1880 apud SCHWARCZ, 2001, p.141-142).

O escravo/artista acabava por ser duplamente explorado, uma vez que seus senhores não se valiam apenas de sua força de trabalho, mas também o utilizavam como fonte de divertimento. Nessa mesma perspectiva, o negro artista ou entertainer (aquele que diverte, que entretém) de hoje seria, assim como no passado oitocentista, visto como "objeto de consumo” (HASENBALG, 1988, p.188), daí a legitimidade conferida ao estereótipo e à mobilidade social conquistada através do entretenimento.

\subsection{4 - A mulata sensual}

A imagem da mulher negra, e especialmente da mulher mestiça, como fortemente sexualizada e dona de uma sensualidade exacerbada é uma representação comum da mulher “de cor” na produção cultural brasileira, estando presente na literatura, por exemplo, desde Gregório de Matos (1636-1695) ${ }^{42}$

No contexto da publicidade, o estereotipo da mulata estaria, juntamente com os estereótipos do trabalhador braçal, artista e atleta, dentro daquilo que Hasenbalg nomeou como atributos do corpo: "vigor e resistência física, ritmo e sensualidade” (HASENBALG, 1988, p.184). De fato, apesar de pouco freqüente em nossa amostra, podemos apontar a valorização do corpo da mulher negra e as referências diretas à questão erótico-sexual como características comuns aos anúncios colocados nessa categoria.

Além disso, a própria presença desses anúncios denota que nas décadas finais do século XX, ainda persistia a visão da mulher negra como objeto sexual, visão essa construída ainda no período colonial escravista.

O anúncio da Credicard traz a mulher negra como corista. Única pessoa negra presente nas 20 fotos que compõem a peça, ela (juntamente com outras três coristas brancas) figura em trajes sumários e adereços na cabeça, supostamente numa apresentação.

\footnotetext{
${ }^{42}$ QUEIROZ JÚNIOR, Teófilo. Preconceito de Cor e a Mulata na Literatura Brasileira. Editora Ática, São Paulo, 1975.
} 

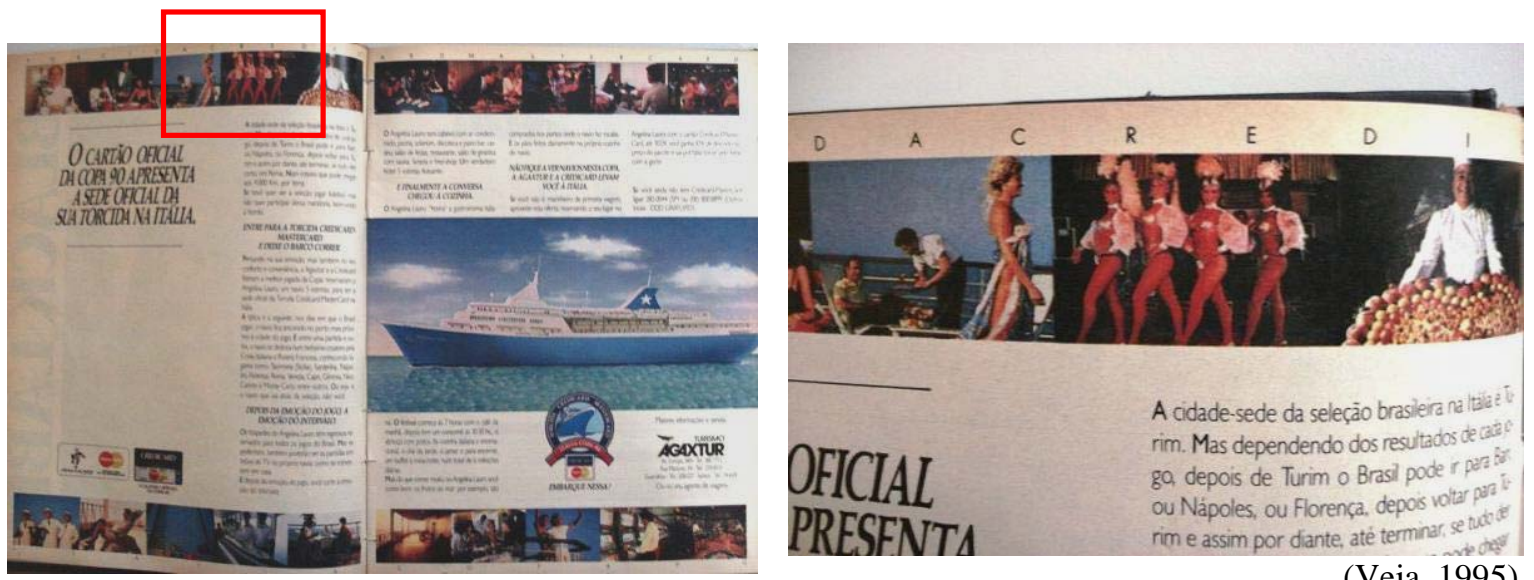

(Veja, 1995)

As outras fotos trazem, por exemplo, mulheres desfilando e casais se divertindo à beira da piscina, mas em nenhum deles há o mesmo nível de exposição do corpo. Ademais, para além da questão sexual, a questão do trabalho deve ser ressaltada: enquanto muitos aparecem se divertindo, a única pessoa negra do anúncio aparece trabalhando, e numa função que não exige qualificação e que também está ligada ao entretenimento. De fato, esse anúncio poderia estar classificado em categorias como o artista ou o trabalhador braçal, mas a proximidade que vemos entre a corista e a "mulata de escola de samba" nos fez optar por colocá-lo nessa categoria.

Já no segundo anúncio, uma campanha do Governo Federal pelo uso de preservativos no carnaval, a mulher negra aparece novamente em minoria com relação às mulheres brancas, com a diferença que neste estão em primeiro plano e não há uma exposição tão grande dos corpos. Contudo, a referência ao ato sexual é extremamente clara: o preservativo aparece em destaque na segunda página, onde há um trocadilho com a expressão "Dê uma dentro nesse carnaval”.

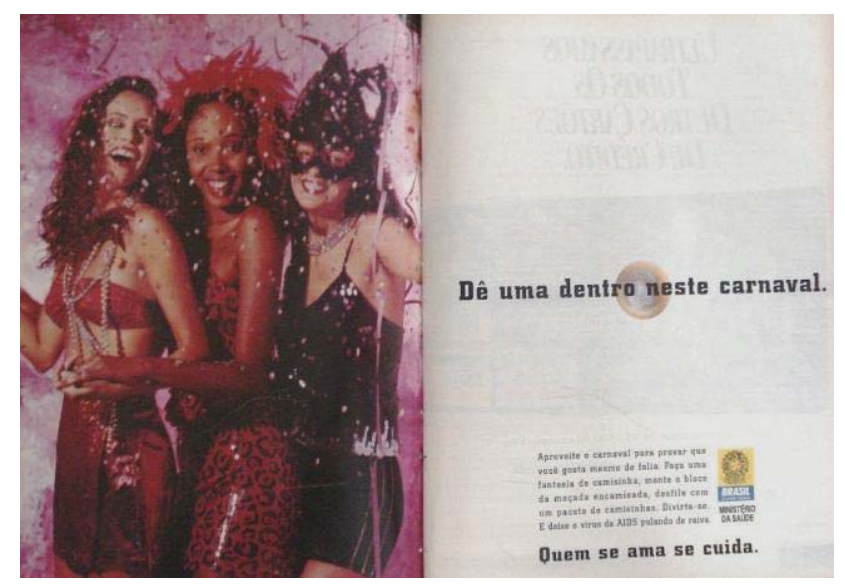

(Veja, 1995)
Outro ponto a ser destacado diz respeito à postura da mulher negra. Ela é a única a encarar, sem disfarces, o público leitor. Podemos reparar que a mulher negra, no centro da foto, parece olhar diretamente para o leitor, enquanto a mulher da direita também olha, mas por trás de uma máscara e a mulher à esquerda tem seu olhar voltado para as outras duas. 
No terceiro anúncio, a questão sexual não é tão acintosa, sendo mais evidente a “coisificação” da mulher negra. Nessa campanha a Vinólia lança uma nova linha de sabonetes, que viriam acondicionados em embalagens desenhadas por artistas plásticos supostamente famosos.

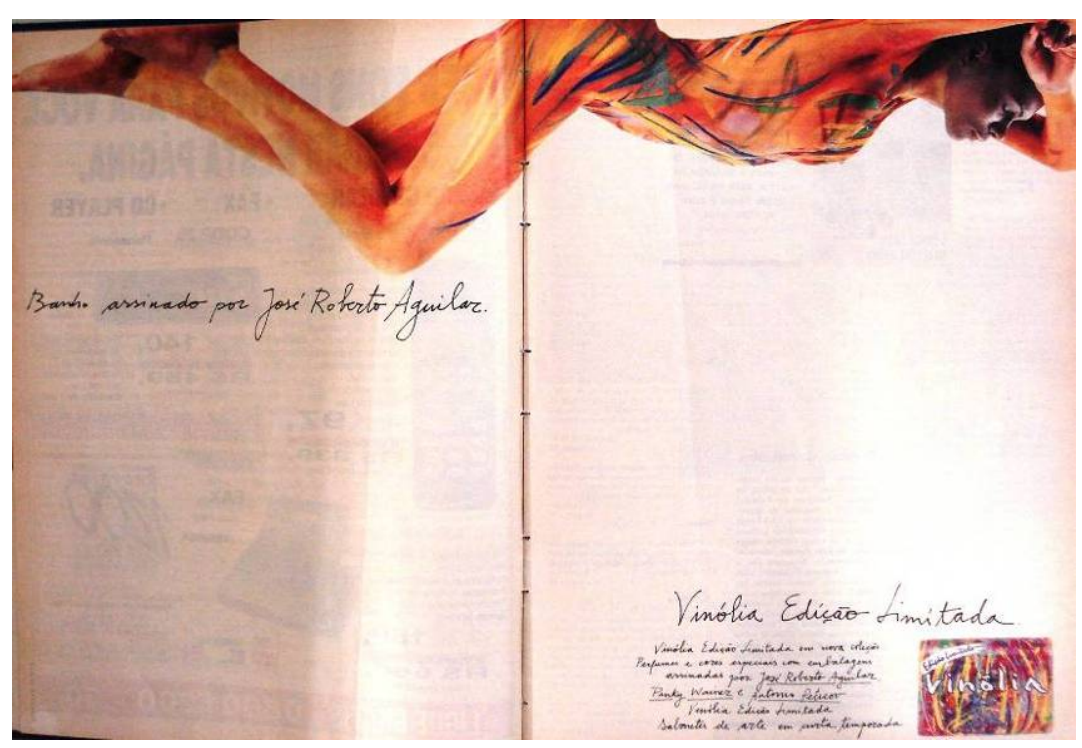

(Veja, 1995)

A modelo negra aparece sozinha no anúncio, em destaque e com seu corpo pintado com motivos similares aos da embalagem. Além de ter seu corpo exposto, a modelo aqui é comparada à embalagem, e serve de tela na qual o artista desenvolve o seu trabalho e, como diz o texto do anúncio, assina a sua obra.

É importante reparar nos anúncios acima (principalmente nos dois últimos) que a despeito das mulheres negras aparecerem em evidência, certas características fenotípicas próprias do negro foram mascaradas. Na campanha do Governo Federal, o cabelo da mulher negra é “disfarçado” com um adereço, enquanto no anúncio da Vinólia o cabelo sequer aparece. Isso sem contar que nesse último anúncio, a própria pele escura da modelo aparece disfarçada pela pintura.

A propósito, cabe aqui dizer que o escamoteamento de certos traços físicos ou a preferência dada a modelos mais claras e de cabelos não tão crespos não é uma exclusividade de anúncios ligados ao estereótipo da mulata. Em outros anúncios em que a imagem da mulher não é ligada ao erótico-sexual, também se colocam modelos negras de características fenotípicas menos pronunciadas. 


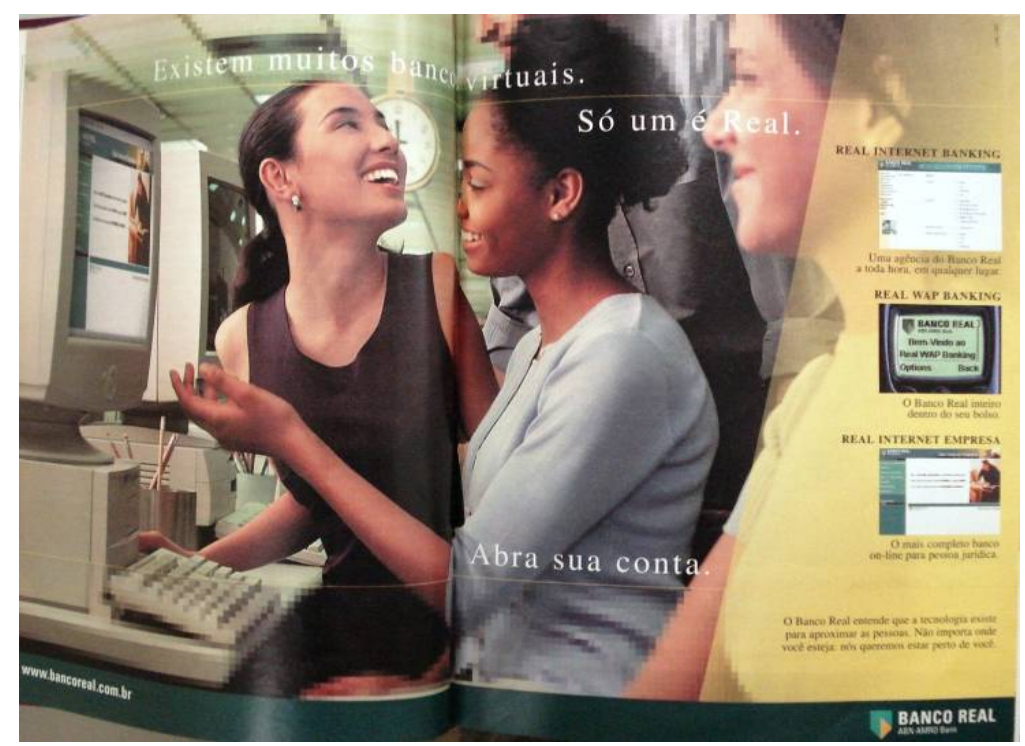

(Veja, 2000)

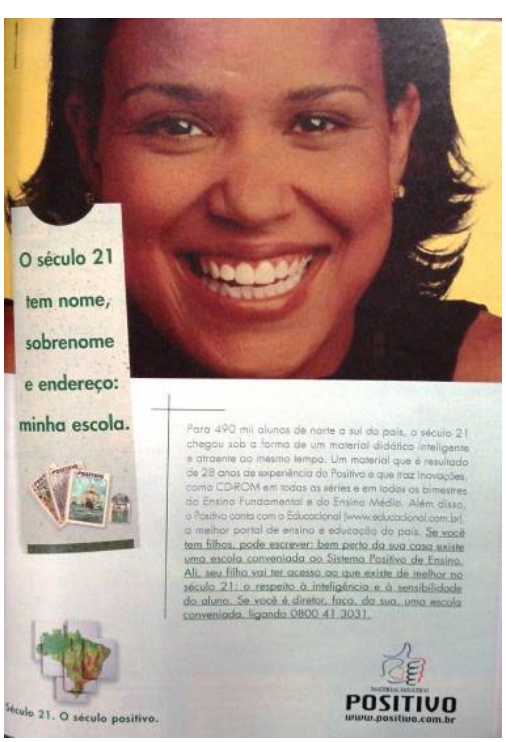

(Veja, 2000)

\subsection{5 - O carente social}

Outra representação que apareceu com freqüência na amostra foi o negro pobre, necessitado, carente social. Esse estereótipo poderia ser encarado como uma releitura, ou uma atualização, da imagem oitocentista do escravo dependente, tido como incapaz de integrar-se ao mundo dos brancos” e sobreviver sem a tutela de seu senhor.

Nessa categoria estão os anúncios de campanhas assistenciais promovidas por fundações ligadas à bancos e empresas privadas, assim como outras Organizações Não Governamentais, que têm como alvo principal (e talvez único) de suas obras o "preto pobre”.

Essas campanhas, em geral, seguem duas linhas: uma é mostrar a realidade dura e triste das pessoas que precisam de auxílio; outra é mostrar essa pessoa já atendida e recebendo os benefícios da ação social realizada. Os dois anúncios a seguir, um da Fundação Abrinq (Associação Brasileira dos Fabricantes de Brinquedos) e outro da Fundação Bradesco são bons exemplos.

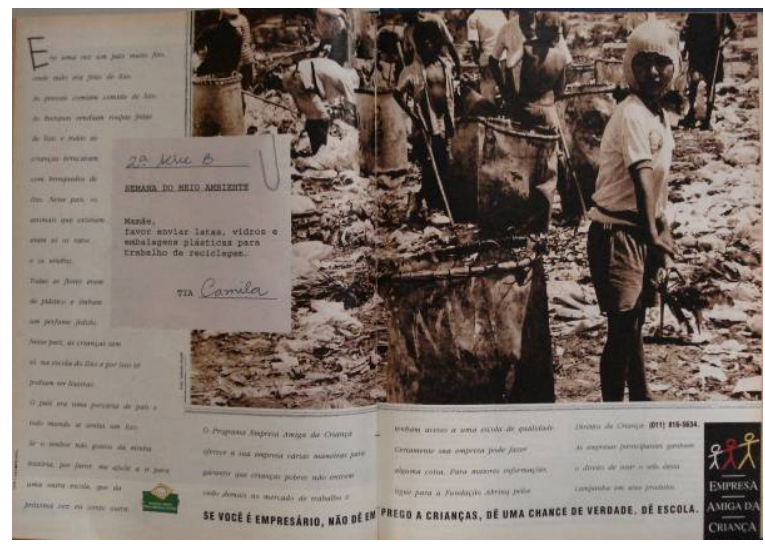

(Veja, 1995)

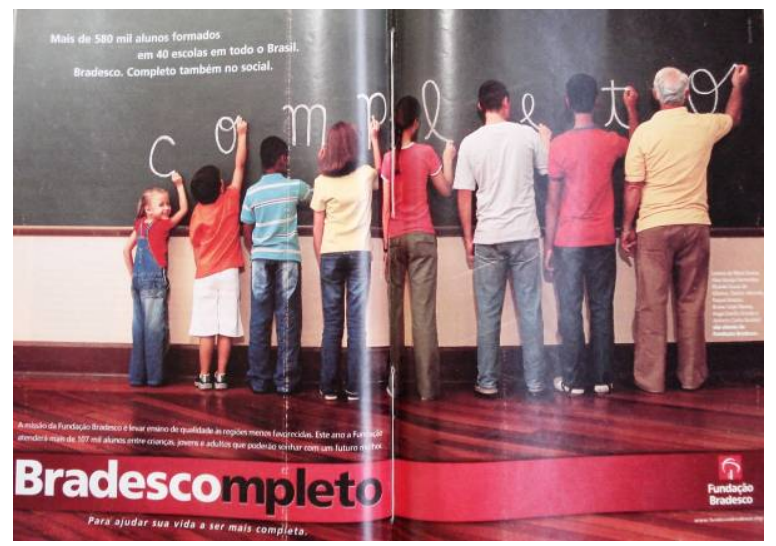

(Veja, 2005) 
O primeiro mostra um grupo de crianças, pelo que se vê todas negras, trabalhando como catadores num depósito de lixo. A foto mostra claramente as condições insalubres em que a criança está, enquanto o texto pede aos empresários que não utilizem mão-de-obra infantil, e os estimula a desenvolver ações no campo educacional. Esse anúncio contrasta bem com o segundo, da Fundação Bradesco, que mostra pessoas de várias idades, e diferentes matizes de pele, numa sala de aula. O ambiente é bastante diferente, todos estão bem vestidos, e a expressão da menina loira no canto (a única que olha para trás) é de felicidade.

Colocar em evidência os rostos dos beneficiados é outra maneira comum de compor anúncios com o negro carente social. Nesses, abre-se mão de um cenário mais elaborado para mostrar de forma destacada as pessoas que se beneficiam da ação social.

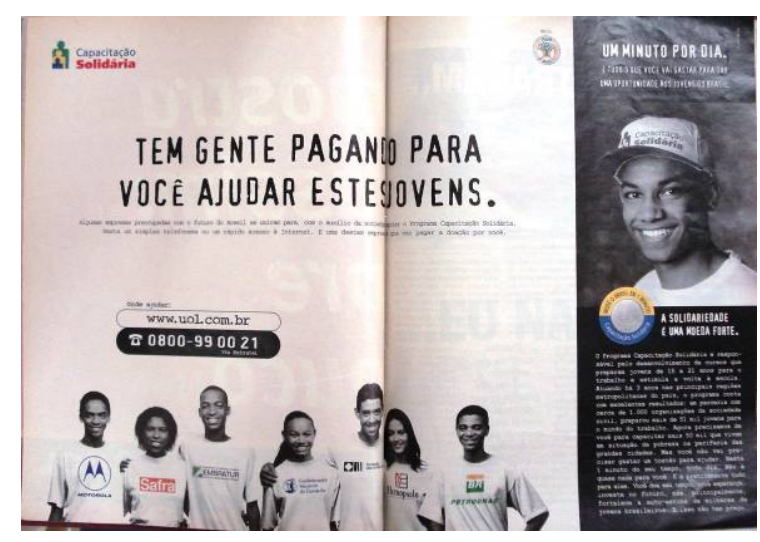

(Veja, 2000)

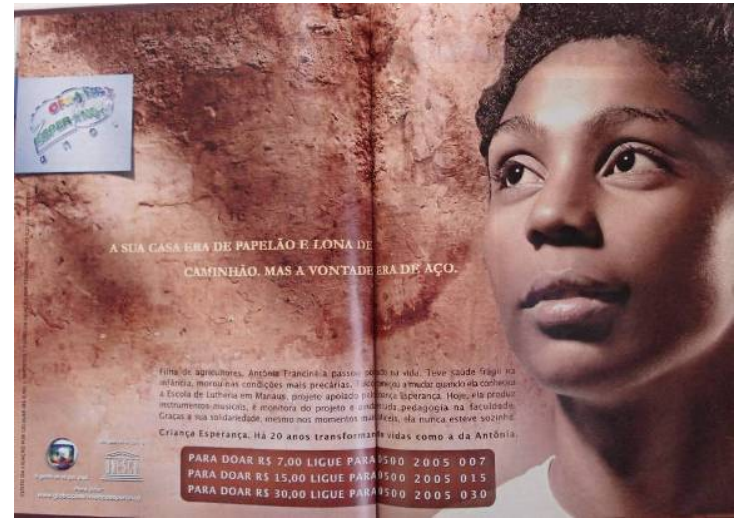

(Veja, 2005)

O anúncio do Capacitação Solidária (à esquerda) mostra oito jovens, quase todos negros, que, como o próprio texto do anúncio exprime, serão ajudados. É interessante reparar que nesse anúncio, assim como no anúncio da Fundação Abrinq, o carente social é mostrado em preto e branco, enquanto as marcas das empresas envolvidas na campanha estão em cores, e se destacam na peça publicitária.

A ação social que é realizada pela Rede Globo de televisão em parceria com o UNICEF (Fundo das Nações Unidas para a Infância), o Criança Esperança, utilizou fórmula parecida para sua campanha de 2005, com a diferença que ao invés de um fundo neutro, utilizou uma paisagem agreste como cenário, e apenas uma jovem beneficiada. No anúncio aparece o nome, sobrenome e local onde vive a jovem, e o texto faz questão de evidenciar sua situação antes e depois de ser ajudada:

Filha de agricultores, Antônia Francinéia passou por quase tudo na vida. Teve saúde frágil na infância, morou nas condições mais precárias. Tudo começou a mudar quando ela conheceu a Escola de Lutheria em Manaus, projeto apoiado pelo Criança Esperança. Hoje ela produz instrumentos musicais, é monitora do projeto e ainda estuda pedagogia na faculdade (...) 
Observando o conjunto desses anúncios, identificamos que eles têm públicos-alvos distintos, do cidadão comum aos empresários, e objetivos igualmente diversos: podem pedir doações (Criança Esperança), buscar apoio de empresários a uma causa (Abrinq) ou apenas mostrar aos consumidores as ações sociais que faz (Bradesco). Em comum têm a forte presença de crianças e jovens negros, mostrados como vítimas excluídas de um sistema ao qual não conseguirão se integrar sem a assistência de um agente externo.

\subsection{6 - O primitivo}

Enquanto as categorias até agora discutidas tiveram como origem a representações oitocentistas do escravo brasileiro, essa traz na sua composição elementos da percepção que se tinha - e de certa forma ainda se tem - da África.

Como discutimos anteriormente, o continente africano desde tempos remotos é considerado o "berço do barbarismo e da superstição". E como nos mostra d'Adesky, a percepção atual não escapa a esse paradigma. $\mathrm{O}$ autor, ao comentar a imagem que a imprensa difunde sobre a região, aponta: “É também difícil encontrar notícias sobre a África que não tratem de conflitos políticos, fome, doenças epidêmicas etc.” (D`ADESKY, 2001, p.96).

Dessa forma, colocamos nessa categoria três anúncios que, em nossa opinião, recuperam essa imagem da África como lugar de povos primitivos, incultos, exóticos. Realmente, a incidência de anúncios nessa temática foi pequena, mas assim como foi colocado no estereótipo da mulata, a simples ocorrência desse estereótipo denota a permanência de uma imagem negativa do continente africano que foi forjada há séculos.

O anúncio da Benetton, grife de roupas famosa por seus anúncios chocantes e polêmicos, traz a foto de uma mulher negra amamentando uma criança branca. Essa imagem, de fato, não é tão alusiva ao continente africano num primeiro momento, mas dá margem a interpretações que podem sim ter a ver com a África.

Uma delas é tomar a imagem da criança branca que se alimenta de uma mulher negra com metáfora da exploração do continente africano pelas nações européias, que haveriam experimentado seu desenvolvimento "alimentando-se" das riquezas africanas. Outra interpretação, essa mais alusiva à escravidão, remonta à imagem da ama de leite, escrava negra encarregada de amamentar os filhos de seus senhores. 


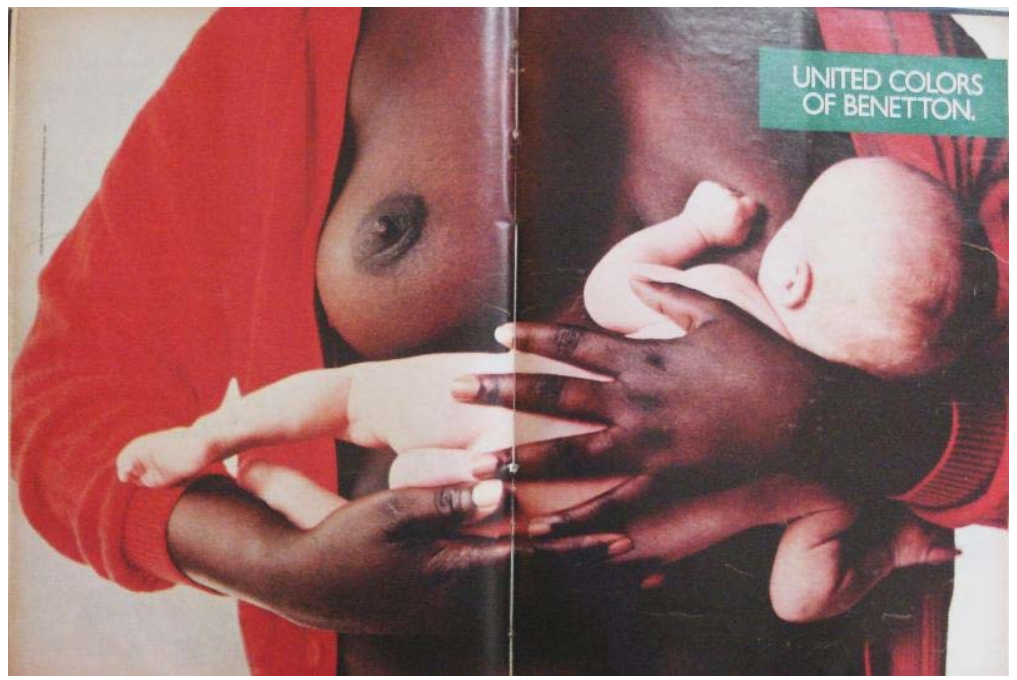

(Veja, 1990)

Os próximos dois anúncios trazem referências mais diretas à “África primitiva”. O anúncio da coleção National Geographic/O Estado de São Paulo, traz imagens de pontos turísticos, animais, acidentes geográficos e, entre elas, dois homens negros vestidos apenas com um tapa-sexo, com seus corpos pintados e tendo ao fundo uma savana. Os dois “primitivos” recebem o mesmo tratamento dado às outras atrações às quais o leitor teria contato adquirindo a publicação, ou seja, são igualmente exóticos e merecedores de serem registrados.

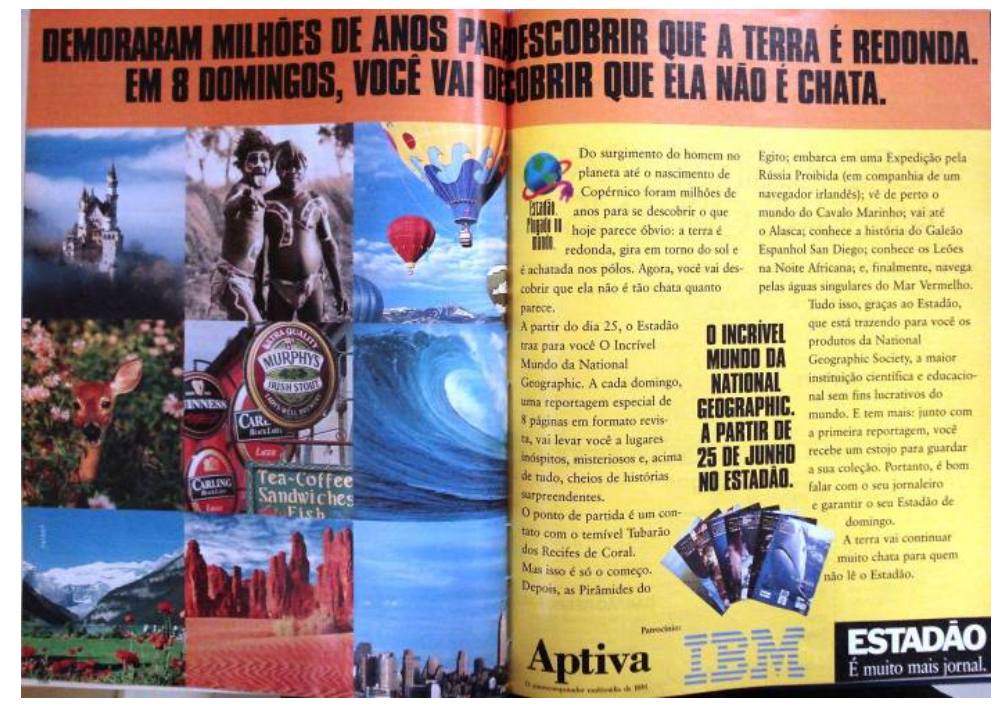

(Veja, 1995)

A peça publicitária da Souza Cruz, indústria tabagista, também traz a figura do negro primitivo, mas aqui não se evoca a qualidade de exótico, mas sim de "povo atrasado". Na foto, um homem negro vestido com uma roupa tribal olha pelo visor de uma câmera de vídeo, e está sendo orientado por um homem branco em trajes tipicamente ocidentais. 
O texto do anúncio traz também um discurso que busca enaltecer o respeito à diferença e a convivência pacífica entre os diferentes. Contudo, a despeito da imagem que coloca numa mesma foto um branco e um negro, a tolerância enunciada no texto refere-se a fumantes e não fumantes: "Pensamentos opostos que se completam, atitudes contrárias que se harmonizam, evolução e tradição, fumantes e não-fumantes”.

Existe no texto um binarismo claro que coloca os fumantes como evoluídos e os nãofumantes como tradicionais, e os apresenta como posicionamentos “opostos” e “contrários”, mas que de alguma forma podem conviver. Esse binarismo é ilustrado, ou melhor, referendado, pela foto, uma

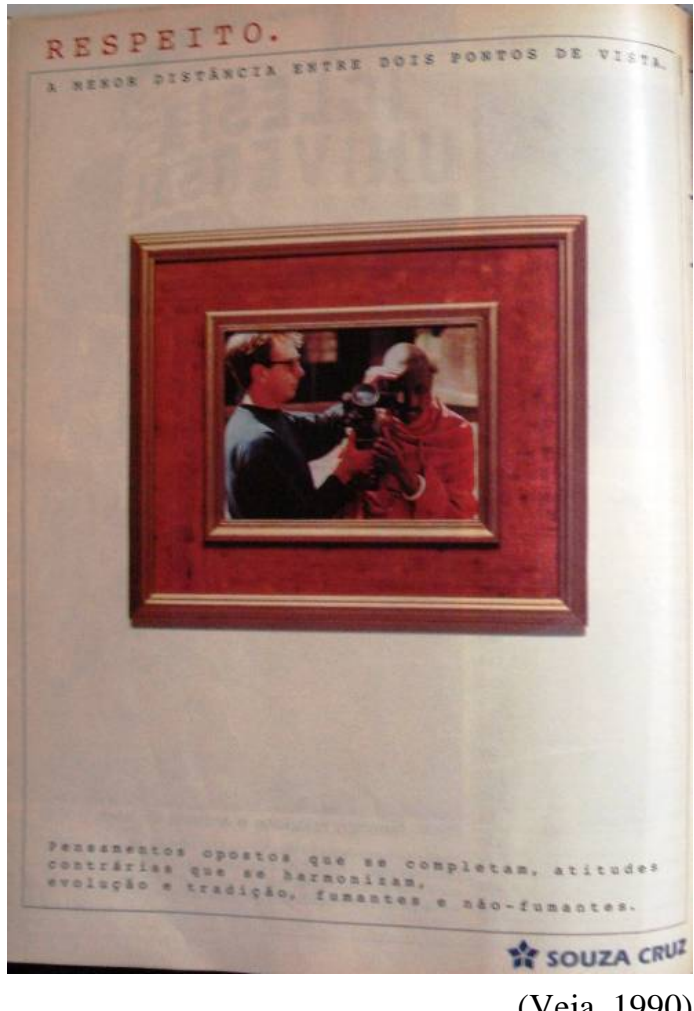

(Veja, 1990) metáfora da convivência possível entre os opostos: o evoluído (branco) e o tradicional/primitivo (negro). Além disso, há que se destacar a utilização do vocábulo “evolução”, termo que, em pleno século XX, parece pouco apropriado para referir-se à relação estabelecida entre grupos distintos.

Se o estereótipo do trabalhador braçal é, como dissemos, o que mais diretamente se relaciona à imagem do escravo, o estereótipo do negro primitivo seria o que mais facilmente se liga às teorias raciais oitocentistas, exatamente por trazerem à tona (de maneira acrítica) imagens e expressões próprias daquele período

\subsection{7 - O negro valorizado}

As seis categorias discutidas até agora trataram de representações que podem ser consideradas subalternizantes e, para usar uma expressão de Canevacci, "guetizantes" do negro brasileiro. Nessa categoria do negro valorizado, reunimos anúncios em que o negro aparece em posição contrária às apresentadas até agora, ou seja, em posições de prestígio e em situação de igualdade (ou quase) os personagens brancos.

No primeiro anúncio, do sistema de cobrança do banco Bradesco, temos uma reunião de equipe da qual participam quatro pessoas, supostamente executivos, uma mulher branca e três homens, sendo dois brancos e um negro. Apesar de não interagir propriamente com os demais, e não ter espaço privilegiado na foto, esse homem negro faz parte da equipe de 
negócios, aparece vestido com roupas semelhantes às do grupo e ainda ostenta um relógio chamativo. Ou seja, o negro que aparece aqui é aparentemente bem sucedido e tem uma profissão que requer qualificação e confere status.

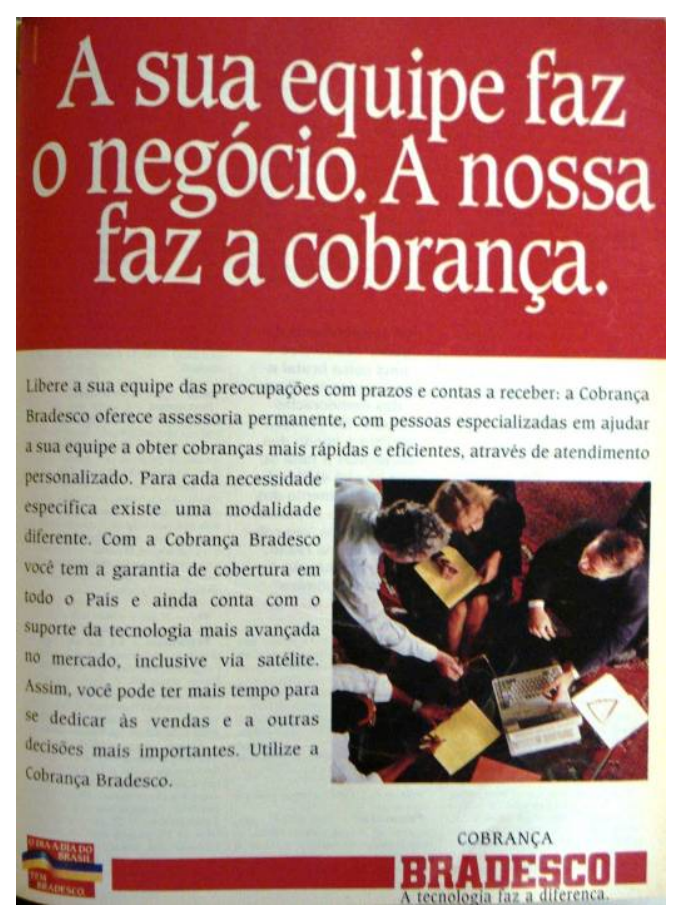

(Veja, 1995)

Os dois anúncios seguintes também tratam profissionais negros qualificados e bem sucedidos. À esquerda, vemos um anúncio que mostra a ganhadora do Prêmio Professor Nota 10, um reconhecimento da TV Cultura e da Fundação Victor Civita a profissionais de destaque na área da Educação. O anúncio traz uma foto da professora segurando o troféu, e como legenda o nome e local onde vive a profissional.

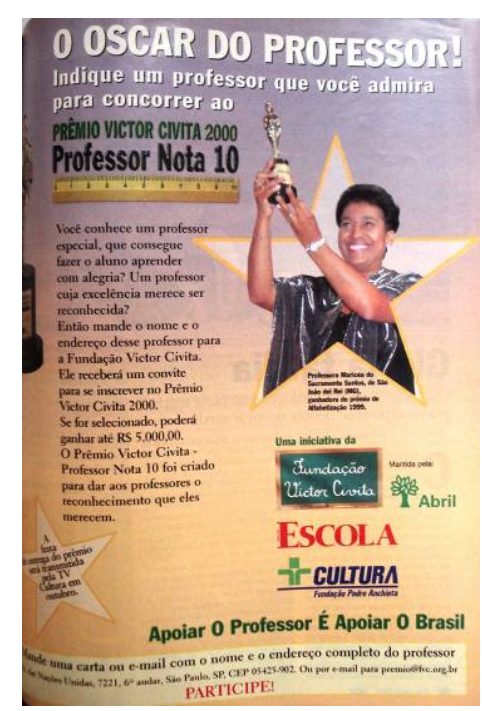

(Veja, 2000)

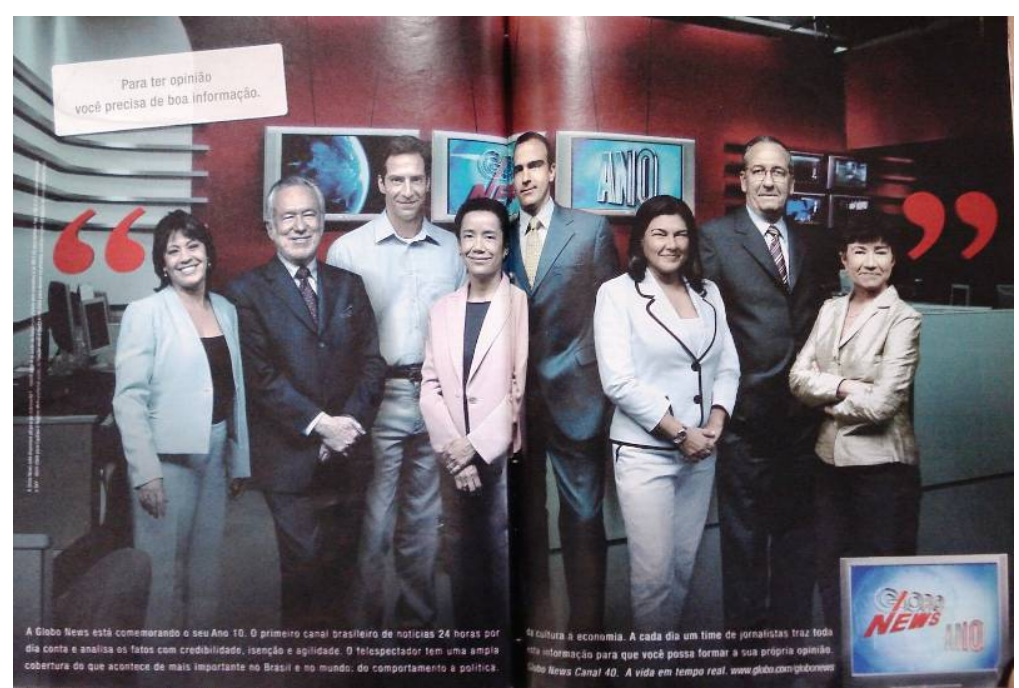

(Veja, 2005) 
Já a peça publicitária do GloboNews, canal de notícias da Rede Globo, nos mostra “entre aspas” a equipe de jornalismo da emissora. Na foto, a jornalista Zileide Silva, comentarista de política e economia, aparece em posição privilegiada e à frente de seus colegas.

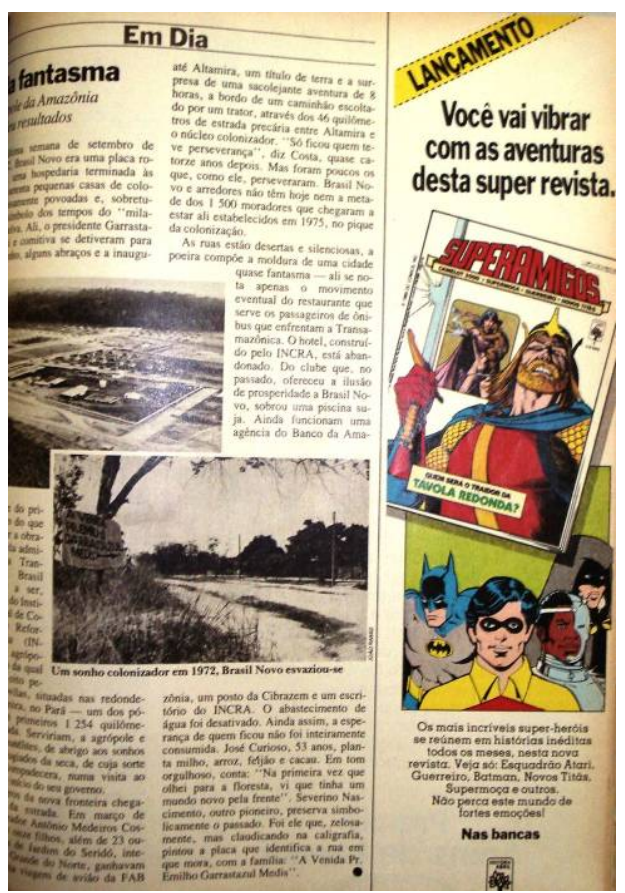

(Veja, 1985)

Além dos profissionais qualificados e/ou destacados, outra forma de representação positiva do negro identificada em nossa amostra foi a figura do herói. No anúncio de lançamento da revista em quadrinhos Super-Amigos entre os heróis presentes está Cyborg, um atleta que num acidente perdeu parte de seu corpo, que foi reconstruído tecnologicamente por seu pai, um cientista. Mais uma vez, temos uma apologia do vigor físico do negro, mesmo assim, a ocorrência de um herói negro é positiva, principalmente num segmento que, assim como os restante da mídia, tem franca maioria dos personagens branca.

As representações valorizadas do negro, dentro do universo da amostra, podem ser consideradas exceções. Da mesma forma que no passado “a exceção só servia para confirmar a regra” (SCHWARCZ, 2001, p.170), hoje as representações positivas não são freqüentes o suficiente para fazer frente às imagens historicamente atribuídas.

\subsection{8 - O anúncios neutros}

Na categoria dos anúncios neutros enquadramos aqueles anúncios nos quais a imagem do negro não aparece relacionada a qualquer um dos estereótipos negativos elencados acima, tampouco tem sua imagem valorizada.

São anúncios em que muitas vezes o negro é o protagonista (ou um dos protagonistas), mas a configuração do anúncio (cenário, texto) e do personagem nada diz sobre o papel social desse negro.

Na peça publicitária da Benetton para o dia dos namorados de 1990, por exemplo, há uma foto com a mão de um homem negro segurando um ramalhete de flores. Não há cenário, não há texto explicativo, não há nenhuma referência que possa levar a um juízo de valor sobre o papel do negro. O mesmo ocorre com o anúncio do jornal O Globo: mais de 90 fotos de 
diversas pessoas, a maioria brancas, que, de acordo com título, são motivos para o Globo mudar. Mais uma vez, não há cenário e o texto é neutro.

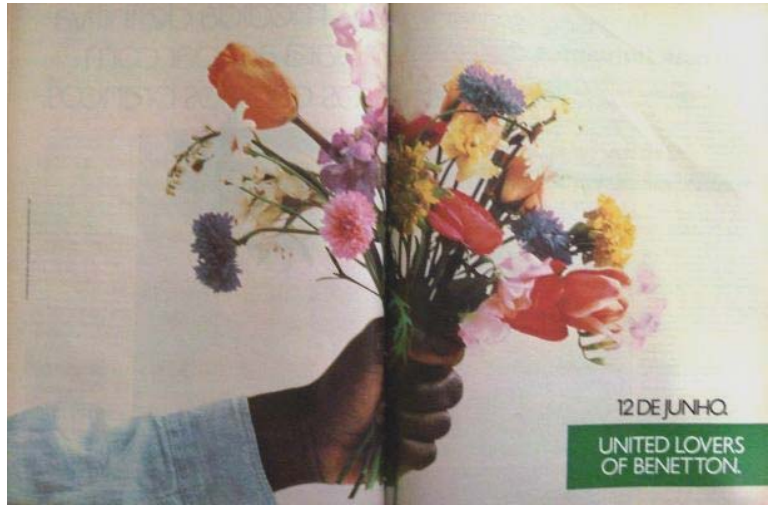

(Veja, 1995)

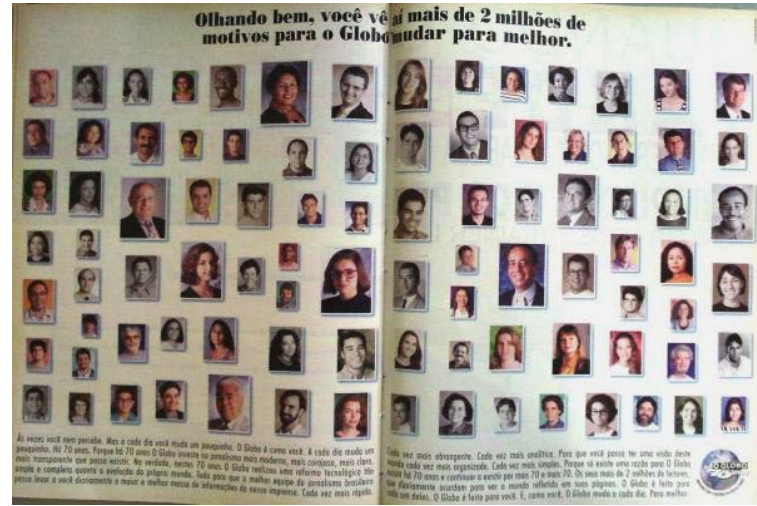

(Veja, 2000)

Nos dois anúncio seguintes, o caso é o mesmo: o fundo neutro, não há legenda que qualifique os personagens, e o texto nada conota. O anúncio do BNDS (Banco Nacional de Desenvolvimento Econômico e Social) trata de uma criação de uma linha de investimentos própria para pequenos e médios investidores. Na foto, aparecem três pessoas uma mulher branca (ao centro) e dois homens, um branco e um negro. Podemos reparar que os dois homens não têm profissão definida, mas faz-se questão de indicar que a mulher branca é médica.

O anúncio da Petros trás uma família negra (evento raro nos comerciais analisados) composta por três mulheres de diferentes gerações (uma senhora, uma jovem e uma criança) e um garoto negro. A peça os apresenta em posição privilegiada, porém o cenário ao fundo também é neutro, e o texto também não indica nada que implique na depreciação ou valorização dessa família negra.

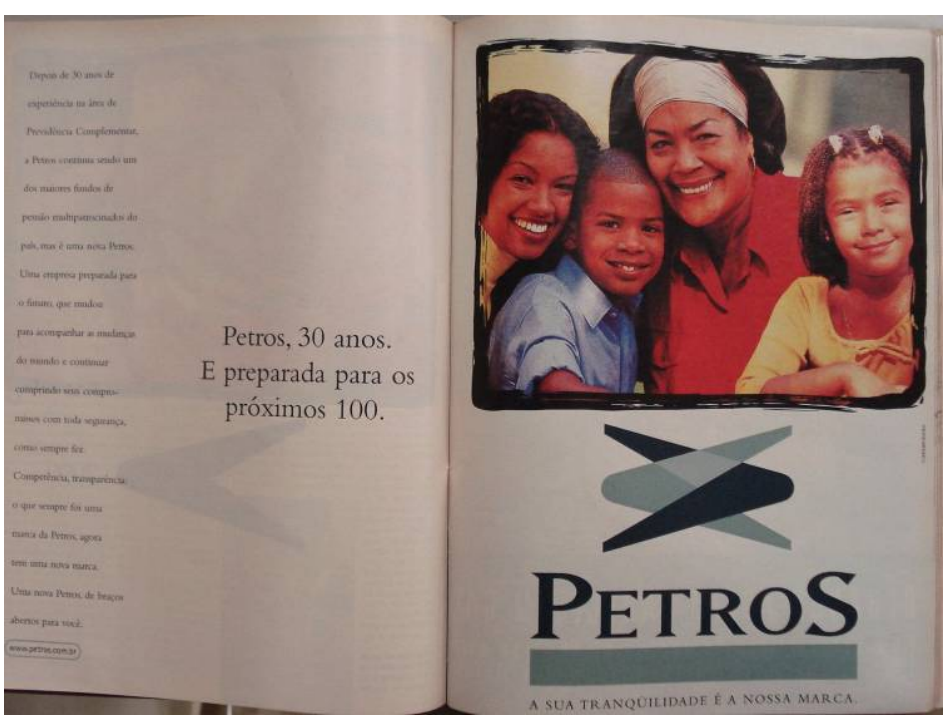

(Veja, 2000)

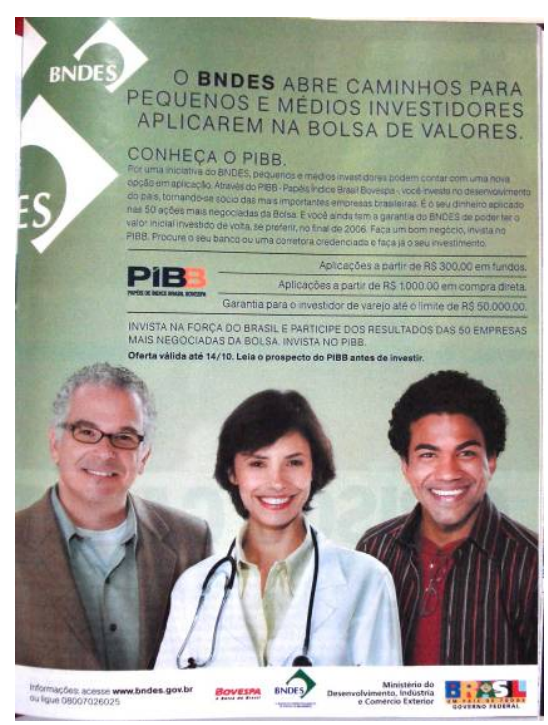

(Veja, 2005) 
Não se pode deixar de reconhecer que a utilização do negro como protagonista, ou com posição privilegiada, nos anúncios tem um lado positivo, vez que colocam o negro em evidência frente uma publicidade que o invisibiliza. Porém, em nossa concepção, a simples aparição do negro não equivale a uma valorização do negro em termos de discurso público.

\subsection{9 - Outros aspectos qualitativos}

Para concluirmos nossa análise qualitativa, gostaríamos de abordar aqui três aspectos que foram abordados rapidamente ou não foram abordados ainda: o negro em segundo plano, os efeitos especiais descaracterizantes e a questão do negro como consumidor.

O uso do negro em segundo plano, ou em posições pouco privilegiadas, é uma característica que apareceu de forma recorrente em nossa amostra. Nesses casos, o negro, representado ou não sob estereótipos é colocado no fundo da cena ou atrás de outros atores brancos, de modo que a percepção de sua presença acaba prejudicada ou nem mesmo notada.

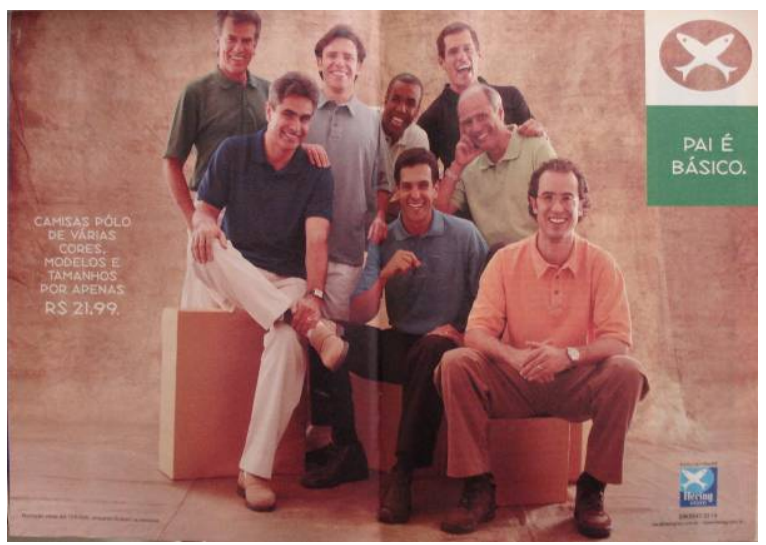

(Veja, 2000)

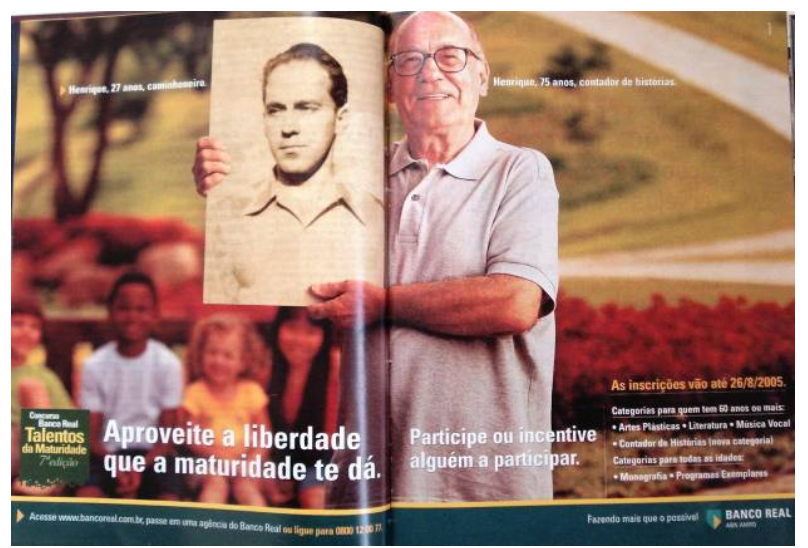

(Veja, 2005)

Os anúncios acima são exemplares. A peça da empresa de roupas Hering para o dia dos pais mostra um homem negro rodeado por outros oito homens brancos. Mas apesar de sua posição central, esse homem negro aparece encoberto por, sendo possível ver apenas sua cabeça e parte do tronco, enquanto a maioria dos homens brancos aparece de corpo inteiro (ou quase). O anúncio do Banco Real Talentos da Maturidade tem uma dupla tentativa de ocultação do negro: enquanto o protagonista, um senhor branco, aparece em destaque no centro do anúncio, um grupo de crianças, incluindo uma negra, aparece ao fundo e com o foco da imagem distorcido.

A propósito, as tentativas de disfarçar a presença do negro podem ocorrer mesmo em anúncios no qual ele é o protagonista. Como vemos no anúncio da Caixa Econômica Federal, a cor da jovem que estrela o anúncio é descaracterizada pelo efeito azul que se coloca na foto. 


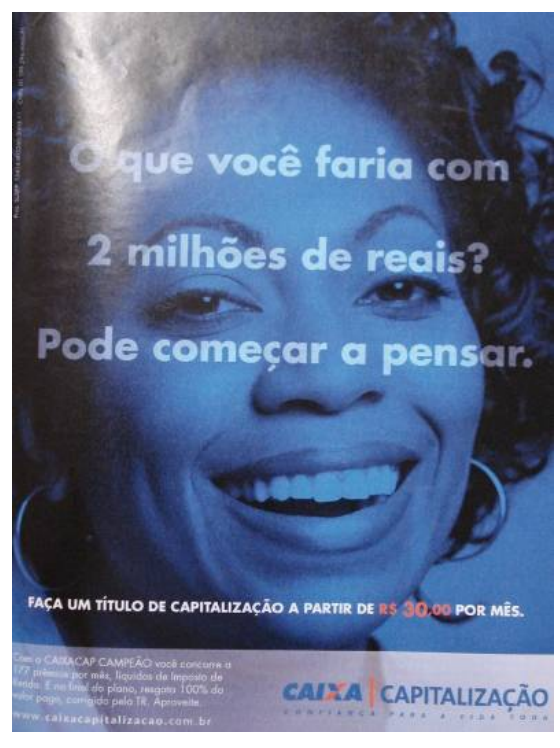

(Veja, 2000)

A utilização de efeitos especiais e trucagens eletrônicas utilizadas com o fim de disfarçar a pele escura de modelos gerou polêmica na imprensa internacional quando em agosto de 2008 (e aqui saio um pouco da amostra) a marca de produtos cosméticos L'óreal veiculou anúncio no qual a cantora estadunidense Beyoncé aparecia branqueada ${ }^{43}$ (abaixo, à esquerda).

Fato parecido, mas que não gerou tamanha repercussão, ocorreu com a atriz brasileira Camila Pitanga, garota-propaganda da joalheria H. Stern no ano de $2007^{44}$. Em diversos anúncios da empresa um efeito de computador alterava a imagem de Pitanga diminuindo o contraste entre o seu tom de pele e a pele de suas antecessoras, a exemplo da modelo britânica Kate Moss no ano de $2005^{45}$ (fotos do centro e da direita).
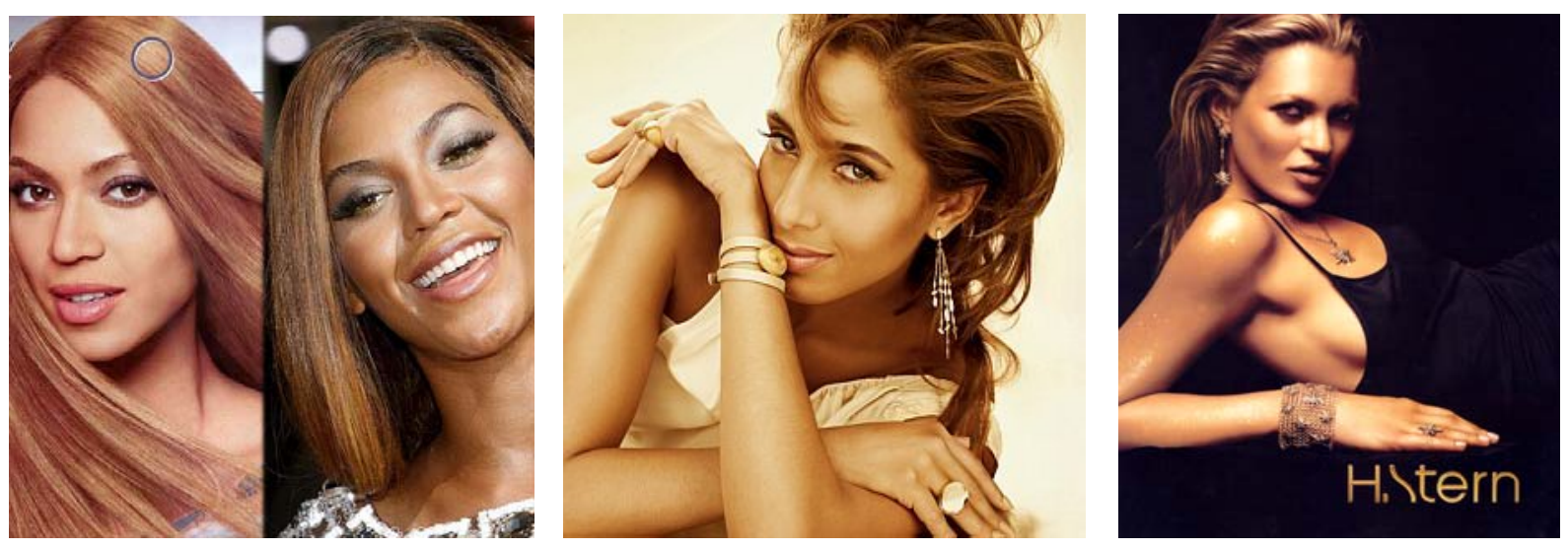

\footnotetext{
${ }^{43}$ http://www1.folha.uol.com.br/folha/ilustrada/ult90u430967.shtml

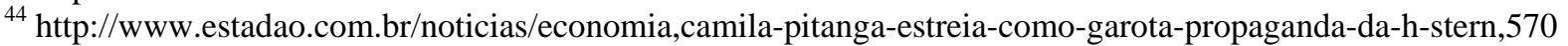
94,0.htm

${ }^{45}$ http://www.publicidadedesaia.blogger.com.br/2005_09_01_archive.html
} 
Voltando ao universo de nossa amostra, queremos destacar a dissociação que geralmente ocorre entre o negro que aparece no anúncio e o produto anunciado. Em muitas peças publicitárias há a presença de negros, contudo esse negro não está usufruindo diretamente do produto ou do serviço anunciado. Em outras palavras: o negro anuncia, mas não consome.

Abaixo apresentamos dois anúncios: um da revista Recreio e outro da Sadia. Podemos reparar que em ambos o personagem negro é um dos protagonistas, e aparecem de forma destacada no anúncio. Porém, nas duas peças, o negro não aparece em contato direito com o produto anunciado.

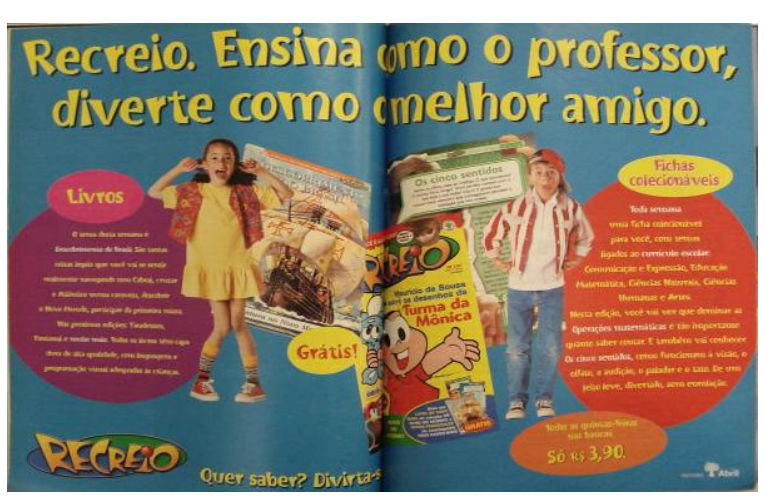

(Veja, 2000)

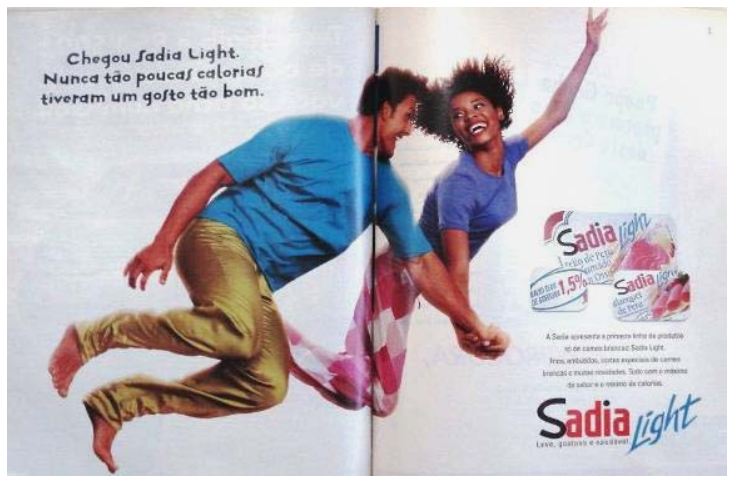

(Veja, 2005)

Segundo Hasenbalg trata-se de uma estratégia utilizada por anunciantes e publicitários para evitar aquilo que classificou como “contaminação”, isto é, “a associação direta entre o negro e produtos específicos” (HASENBALG, 1988, p.186-187).

De fato, foram poucos os anúncios em que o negro apareceu consumindo. Um dos

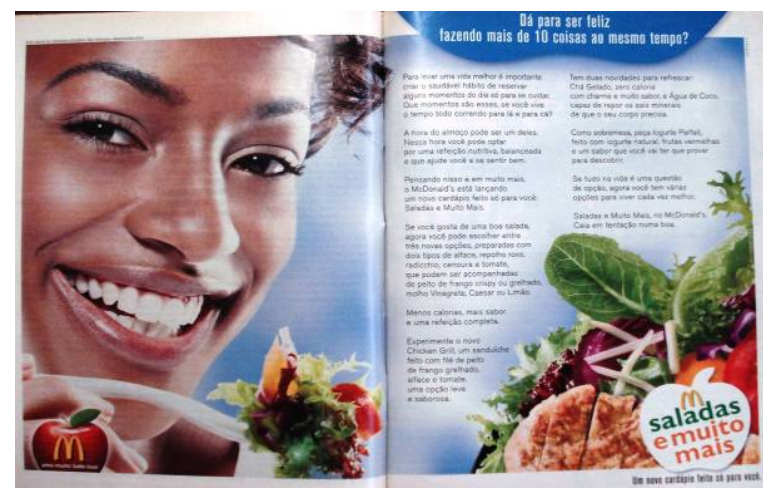

(Veja, 2005) raros exemplos encontrados foi essa peça da rede de lanchonetes McDonald's, na qual a modelo negra, a despeito de não estar numa das lojas da rede, aparece comendo a salada anunciada.

Naturalmente, muitas outras observações poderiam ser feitas a respeito dos anúncios aqui apresentados neste e nos demais tópicos - da mesma forma, poderíamos ter inserido mais anúncios ou apresentado outras divisões. Contudo, nossa proposta não é esgotar o universo pesquisado, sob pena de redundâncias e repetições desnecessárias. Procuramos inserir aqui os anúncios que, em nossa opinião, são os mais representativos de suas categorias, reconhecendo 
desde já que muitos deles poderiam estar em categorias diferentes, ou mesmo serem incluídos em mais de uma categoria.

Assim, acreditamos que os dados e discussões trazidos nesse capítulo sejam suficientes para tecermos algumas conclusões e considerações finais, o que passaremos a fazer no capítulo seguinte. 


\section{CONSIDERAÇÕES FINAIS}

Brancos em cima, negros embaixo, Ainda é normal, natural 400 anos depois,1992, tudo igual, Bem-vindos ao Brasil colonial e tal...

Racionais MC's

Pesquisas recentes, realizadas principalmente no início da década de 2000, apontam para o fato de que hoje negros e mestiços ocupam lugar de destaque na publicidade brasileira. Exemplo de trabalho nessa linha é o artigo $O$ apelo da cor: percepções dos consumidores sobre as imagens da diferença racial na propaganda brasileira, no qual Ilana Strozenberg afirma não haver dúvidas de que a "presença da diferença racial” na publicidade brasileira adquiriu importância inédita nesses últimos anos, e assevera que tal alteração não é apenas de ordem quantitativa, manifestando-se também nas características dos personagens e nos lugares que o negro ocupa nas imagens publicitárias (STROZENBERG, 2005, p.200).

De acordo com a autora, até meados da década de 1980 o negro só aparecia em papéis subalternos e coadjuvantes, situação que não seria aplicável à realidade hodierna. Para Strozenberg, na publicidade mais atual, modelos negros são utilizados para vender os mais diferentes produtos e serviços, de moda a eletrodomésticos, sendo que agora a diferença de cor aparece como característica positiva que agrega prestígio e sedução ao produto anunciado (STROZENBERG, 2005, p.200-201).

Hoje, muitos modelos negros disputam o mercado publicitário. Cada vez mais, rostos e corpos escuros ocupam lugar de destaque nos outdoors, nas páginas de revistas e jornais, nos comerciais de televisão, parecendo colocar em cheque a continuidade ou, pelo menos, a legitimidade inquestionada do ideal de embranquecimento que, tradicionalmente, sempre foi a tônica das concepções sobre as relações raciais no Brasil (STROZENBERG, 2005, p.209).

Sem querer contestar a validade desta e de outras pesquisas que seguem a mesma linha, os dados que apresentamos ao longo do trabalho não nos permite compartilhar de tamanho otimismo.

Obviamente, reconhecemos que dentro do período analisado houve sim alteração positiva na participação do negro no segmento publicitário. Se voltarmos aos aspectos quantitativos, verificaremos que a proporção de anúncios com a presença de negros subiu de 3\% do total em 1985 para 13\% em 2005, e que o número de personagens negras cresceu de 1\% em 1985 para 7\% em 2005.

Nesse mesmo sentido, veremos que a proporção de anúncios nos quais o negro aparece representado sob estereótipos subalternizantes caiu de 75\% em 1985 para 43\% em 2005, isso 
sem falar que em 1985 o negro aparecia sozinho em 12,5\% dos anúncios, número que foi de $28 \%$ em 2005.

Contudo, ainda que reconheçamos tais melhoras como conquistas da população negra e as tomemos como avanço, acreditamos serem elas extremamente modestas, de forma que não podem ser consideradas indícios de ruptura radical, ou mesmo de uma postura totalmente nova do segmento publicitário com relação às tradicionais formas de veiculação da imagem do negro.

Além de um crescimento que pode ser considerado lento (10\% em um intervalo de 20 anos), entendemos que a proporção de $13 \%$ de anúncios com negros não é suficiente para que possamos por de lado a questão da invisibilidade. Da mesma forma, os $43 \%$ de anúncios estereotipados que encontramos em 2005, são provas da forte persistência de certas representações ainda no século XXI.

Ademais, é importante ressaltar que a diminuição no número de anúncios estereotipados não ensejou aumento no número de anúncios valorizantes, mas veio acompanhada de crescimento na proporção de anúncios nos quais a imagem do negro foi considerada neutra. Enquanto o percentual de anúncios valorizantes cai pela metade se compararmos os anos inicial e final da nossa amostra, 12\% em 1985 e 6\% em 2005, os anúncios “neutros” sobem de $12 \%$ para 50\%, considerando o mesmo período.

Portanto, ao invés de falarmos em valorização, acreditamos ser mais correto falarmos em processo de neutralização da imagem do negro, uma vez que, segundo os dados, o número de anúncios neutros chega a superar os anúncios estereotipantes.

Naturalmente, poderíamos ser confrontados com o argumento de que uma imagem neutra seria menos deletéria que uma imagem negativa - e que isso por si só já representaria um avanço. Todavia, cabe aqui questionar até que ponto essa imagem "neutra” contribui para uma efetiva mudança da imagem pública do negro.

Alguns pesquisadores considerariam certos anúncios, neutros principalmente, como valorizantes ou até mesmo contra-intuitivos ${ }^{46}$ exatamente porque o negro aparece como protagonista, em posição destacada e algumas vezes no papel de consumidor. Porém, tais

\footnotetext{
46 "A propaganda com estímulos contraintuitivos é uma 'tentativa deliberada de romper com os antigos estereótipos com a produção que se pode chamar de cartazes contraintuitivos'. O antropólogo Peter Fry adota esta expressão para apontar as comunicações publicitárias, nas suas diversas formas, que rompem com a tradição ao expor em seus enredos representantes de grupos minoritários, principalmente o negro, em posições de prestígio social. (...) a propaganda contra-intuitiva avança na questão do apenas conter (inserir) um representante de um grupo minoritário em sua estrutura narrativa, nela o indivíduo alvo de estereótipos e preconceito social é alçado ao patamar de protagonista/antagonista e ou destaque do enredo publicitário, posições que antes eram restritas a determinados perfis sociais” (LEITE, 2008, p.131-141).
} 
pesquisadores se esquecem de observar esses anúncios à luz de um contexto mais amplo, no qual o branco não aparece neutro, e sim valorizado, isto é, não levam em conta a branquitude.

Longe da pretensão de aprofundar-nos no tema, gostaríamos apenas de colocar que, como afirma para Maria Aparecida Silva Bento, a construção de um imaginário negativo sobre o negro tem como outro lado da moeda justamente o fortalecimento da auto-estima e do auto-conceito do grupo branco, que assim como qualquer outro grupo social precisa de referenciais positivos sobre si próprio para fortalecer-se. A questão é que, dentro desse processo, pouco se percebe e pouco se discute o papel do branco na conformação das desigualdades raciais (BENTO, 2003).

O anúncio abaixo, da Portobello, é emblemático sobre essa questão. Veiculada em 1992 (e aqui saio mais uma vez da amostra), a peça trás à esquerda uma imagem que seria o presente, como indica a expressão "hoje” no alto. Nessa foto estão cinco crianças, três brancas, uma asiática e uma negra. À direita, contrastando com a página anterior, está uma foto do que seria o futuro, dada a expressão “amanhã”. Aí as crianças já se tornaram adultas e as roupas parecem definir suas ocupações: as crianças brancas tornaram-se executivo, donade-casa e atleta; a asiática tornou-se uma cientista; e o negro um frentista de posto de gasolina.

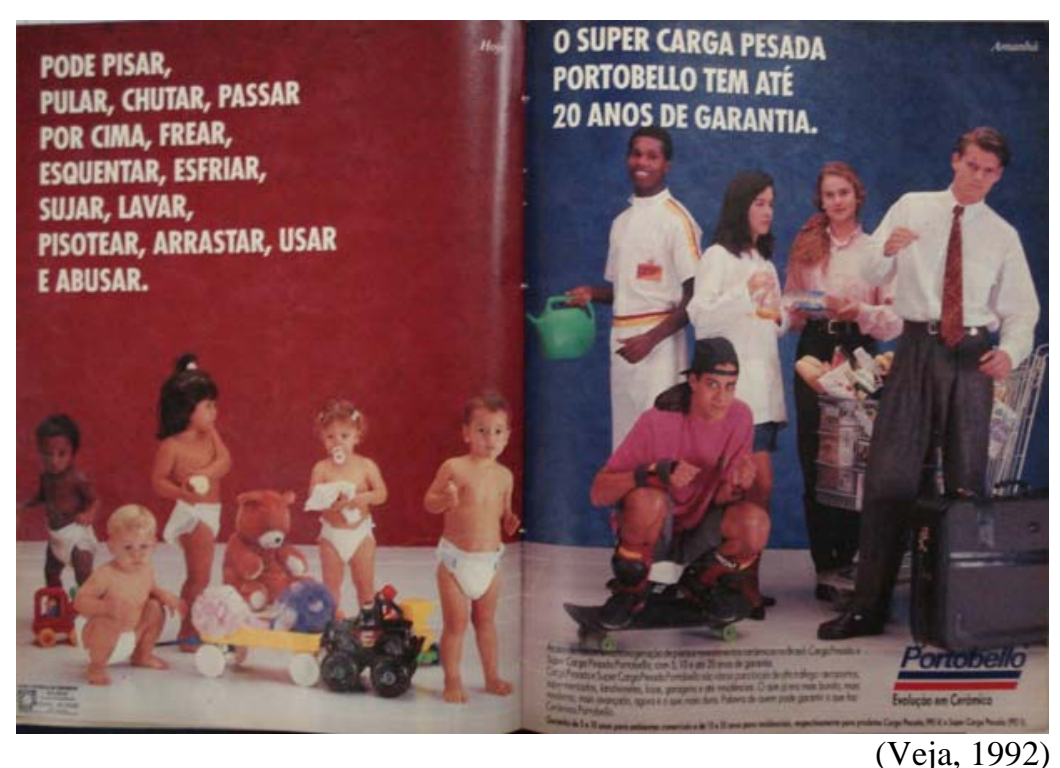

Importa destacar que nesse anúncio não temos apenas uma representação subalternizante do negro, mas temos também representações valorizantes do branco, ou seja, mais do que definir o lugar do negro, aponta-se também qual o lugar do branco na sociedade: o fatalismo nada sutil que “condena” a criança negra a ter uma profissão pouco prestigiosa na idade adulta, é o mesmo que vai prenunciar o "futuro promissor” das crianças brancas. 
Não se trata então de pensar somente nos papéis sociais do negro, mas sim ter em perspectiva os papéis sociais do negro em relação aos papéis dos brancos. E nesse sentido entendemos que os anúncios neutros pouco, ou nada, contribuem para a valorização do negro, podendo, ao contrário, serem encarados como uma nova forma de manifestação do racismo.

De acordo com Marcos Emanuel Pereira e Marcus Eugênio Lima, mudanças políticas e sociais ocorridas entre as décadas de 1940 e 1960, a exemplo da Declaração dos Direitos Humanos (1948), a luta pelos direitos civis nos EUA e o movimento feminista, fizeram mudar as formas de expressão do preconceito e do racismo, interferindo na expressão pública dos estereótipos contra as minorias (LIMA; PEREIRA, 2004, p.9).

Como conseqüência direta dessas mudanças históricas e das conquistas políticas das minorias, as formas de expressão do preconceito sofreram mudanças significativas. Uma série de pesquisas realizadas mediante o uso de metodologias tradicionais de coleta de dados ou medidas diretas de atitudes raciais, feitas em lugares e épocas diferentes, demonstram que as atitudes contra os negros, as mulheres, homossexuais, imigrantes e outras minorias estão mudando significativamente, ao nível das suas expressões públicas (LIMA; PEREIRA, 2004, p.10).

Considerando o contexto brasileiro, podemos pensar que a mobilização do movimento negro e outros setores da sociedade em torno da luta anti-racista nos últimos anos logrou trazer à ordem do dia reivindicações e denúncias a respeito das várias formas de discriminação sofridas pela população negra, o que teria suscitado uma atenção maior de órgãos governamentais e da sociedade civil como um todo.

No terreno midiático, a resposta das elites logotécnicas ${ }^{47}$ às reivindicações da população negra teria vindo na forma de uma inclusão que, de certa forma, afasta o negro das representações subalternizantes, mas por outro lado, não o insere no rol dos segmentos valorizados. Essa inserção "pro forma” do indivíduo escuro nas produções televisivas e publicitárias cumpriria assim com a função de evitar críticas e contemplar certas aspirações dos movimentos sociais.

Outra prova disso está na variação de certas representações ao longo do período estudado. Se observarmos os números ano a ano, perceberemos que a freqüência de certos estereótipos diminuiu (e até mesmo cessou), enquanto outros experimentaram pouca alteração.

O trabalhador braçal, por exemplo, correspondia, em 1985, a 50\% dos anúncios com negros, número que caiu para 3\% em 2005, e os estereótipos do africano e da mulata não são encontrados na amostra depois de 1995. Por outro lado, o estereótipo do atleta experimenta

\footnotetext{
${ }^{47}$ Sodré chama de "elite logotécnica” os profissionais dos blocos dirigentes dos meios de comunicação de massa - articulistas, editorialistas, cronistas, editores (SODRÉ, 1999, p.29).
} 
certo crescimento (de 14\% em 1985 para 19\% em 2005), ao passo que o carente social e o artista permanecem praticamente estáveis, ambos com variação de $14 \%$ para 12,5\% no mesmo período.

Isso significa que se de um lado alguns estereótipos foram praticamente “abandonados” ou desapareceram, de outro, certas representações conservaram suas médias praticamente inalteradas.

Assim, levando em conta que a presença de negros nos anúncios continuou baixa; que a proporção de anúncios valorizantes diminuiu; que os anúncios neutros aumentaram, mas não podem ser considerados propriamente positivos; e que a proporção de anúncios estereotipantes caiu, mas permaneceu expressiva, consideramos lícito pensar que a publicidade brasileira mais atual não abriu totalmente suas portas ao negro, e que as conclusões de pesquisadores como Strozenberg são passíveis de serem revistas.

E se formos um pouco mais além nessa questão, veremos que nossa hipótese de que a publicidade mais atual perpetua, de maneira atualizada, o mesmo tratamento marginalizador e subalternizante historicamente dispensado ao negro pelas diferentes formas de produção cultural tem validade.

Como procuramos discutir no decorrer do trabalho, além da invisibilidade, que ao longo do tempo vem “tirando o negro de cena” (parafraseando Hasenbalg), as imagens veiculadas pela publicidade seriam, em última análise, releituras dos mesmos estereótipos negativos sob os quais o negro vem sendo retratado desde o século XIX.

O estereótipo do trabalhador braçal ou trabalhador não-qualificado, por exemplo, tem forte relação com a imagem do escravo bruto, boçal, que considerado naturalmente desprovido de capacidade intelectual só poderia ser aproveitado por meio de sua força física, assim como o africano (primitivo, atrasado, exótico) e o atleta (que se destaca pelo vigor físico) também podem ser entendidos como uma atualizações da bestialidade atribuída ao cativo.

Já o carente social poderia ser associado ao escravo dependente (incapaz de se integrar ao modo de trabalho livre e sobreviver por conta própria) ou ao escravo vítima (indefeso frente à opressão que lhe aflige); o estereótipo do artista à visão do negro como objeto de consumo e fonte de divertimento; e o estereótipo da mulata significaria a continuidade de um olhar que valoriza a mulher escura apenas por seus atributos estéticos e por sua suposta voluptuosidade exacerbada.

Quando falamos em atualização, releitura ou continuidade, estamos partindo do pressuposto que a representação não é um “fenômeno estanque e cristalizado” que não admite 
transformação (SCHWARCZ, 2001, p.253). Schwarcz, citando Peter Fry, afirma que as representações não são um "retrato fixo”, ou seja, "não são um único conjunto que resiste às mudanças do tempo", e sim "imagens em movimento que guardam continuidade, mas que também admitem transformação (SCHWARCZ, 2001, p.250).

Não se constitui dessa forma um processo linear de substituição e introdução de novas idéias, sendo que as representações ganham sentido antes como grupo de variantes no interior de um contexto que lhes transcende e dá sentido, e não como individualidades isoladas e entendidas numa perspectiva atemporal (SCHWARCZ, 2001, p.250).

Nesse sentido, poderíamos entender que tanto a ausência como a estereotipação dos negros promovida pelos meios de comunicação de hoje são frutos daquilo que Sodré chama de traço, ou seja, um “signo presente de um passado ausente” (SODRÉ, 1999, p.118).

O traço seria "um conector histórico, uma espécie de fio intergeracional que preserva os valores éticos de um passado pronto a ser narrado”. Como argumenta o autor, as elites brasileiras vêm há tempos narrando uma história sobre o país cuja continuidade dá-se através de traços de uma mesma forma social; em outras palavras, "reinterpretam-se determinados traços (documentos, textos, idéias, atitudes) como uma ligação ética entre passado e presente” (SODRÉ, 1999, p.118-119).

Mas esse ethos, diz Sodré, não seria "puramente cultural ou exclusivamente simbólico": ele teria servido sempre, no interior de práticas políticas, como "filtro seletivo" para controlar o acesso dos segmentos subalternos à estrutura de poder, bem como utilizado “para polir as arestas das relações raciais e impedir reações radicais” (SODRÉ, 2009, p.124).

Portanto, pode-se dizer que da mesma forma que na passagem do século XIX para o século XX o registro branco do Brasil se consolidou enquanto reação à ascensão da população negra ao status isonômico de cidadão, a sua perpetuação até os dias de hoje, mesmo que sobre outras bases, é também uma resposta (ou um mecanismo de resistência) à luta da população negra por uma igualdade isotópica - isto é, a persistência do registro branco do Brasil significaria a persistência da funcionalidade política do racismo ${ }^{48}$.

E da mesma forma que as representações pejorativas do passado não podem ser vistas como uma estratégia deliberadamente montada pelas elites da época, a invisibilidade e as representações atuais - conquanto não sejam inocentes - também não podem ser encaradas como uma realidade intencionalmente forjada com base no eurocentrismo do passado.

\footnotetext{
${ }^{48}$ Sodré chama de isonomia a igualdade perante os sistemas jurídico e social, ou seja igualdade isonômica é a igualdade formal, a igualdade perante a lei. Isotópica seria a igualdade de acesso aos lugares, ou seja, igualdade na ocupação de postos de trabalho, de vagas nas instituições escolares, na mídia, entre outros (SODRÉ, 1999, p.262).
} 
Na verdade, essa reprodução das formas sociais anteriores é o que permite aos sujeitos do poder presente reencontrarem-se com os do passado histórico, e assim legitimarem-se (SODRÉ, 1999, p.119). Ou, como diria Canevacci:

A hegemonia expansionista eurocêntrica foi como que diluída, dissolvida e considerada aceitável nos países “outros” (...), salvando, pelo menos em parte, as tradições ancestrais de uma queda mnemônica. Enxertados, transplantados nas culturas do vencedor, os "arcaísmos" localistas puderam se vivificar; o animismo, não mais totalmente desarraigado de um novo conceito da alma vinda de fora, pôde tornar a animar-se (CANEVACCI, 1990, p.173, grifo do autor).

Fica claro, portanto, que a maior inserção de negros na publicidade não vem ocorrendo por conta de um reconhecimento de seu status de cidadão, tampouco tem a ver com respeito pela dignidade da pessoa humana - já que, como afirma Dalmo de Abreu Dallari, o direito de ser pessoa é desrespeitado "quando seres humanos sofrem violência de qualquer espécie, nascendo na miséria, sendo forçados a viver em situação degradante ou humilhante, ou sendo tratados com discriminação” (DALLARI, n/d, p.37, grifo nosso) - ou com igualdade de direitos e oportunidades.

Entretanto, seria um equívoco da nossa parte restringir as razões de tal avanço somente à pressão dos movimentos sociais, desprezando a motivação mercadológica, haja vista que a função primeira da publicidade é o estímulo ao consumo.

Até o final da década de 1980, muitos publicitários brasileiros, apesar de reconhecerem a existência de racismo no país, creditavam a invisibilidade do negro ao seu (suposto) baixo poder aquisitivo. Isso fica evidente, por exemplo, na declaração que o publicitários como Ênio Mainardi deu à Revista Propaganda em 1988, quando esta, por conta do Centenário da Abolição, publicou matéria especial sobre a situação do negro no segmento:

A propaganda não é revolucionária, ela vive de clichês sociais, dos preconceitos, só mostrando aquilo que as pessoas querem ver. Nos comerciais, as pessoas querem se ver representadas, numa verdadeira projeção psicanalítica, como lindas, ricas, poderosas. E os pretos são pobres meu amor (PIRES, 1988, p.15).

Na mesma reportagem, o também publicitário Washington Olivetto deu declaração na qual concordava que poderia existir um preconceito velado de agências e anunciantes no Brasil, contudo dizia que o problema fundamental estaria no fato de que grande parcela da população negra encontrava-se marginalizada economicamente: " $E$ a propaganda trabalha com o estereótipo da maioria das pessoas”, disse à época (PIRES, 1988, p.18).

A luta do negro pelo reconhecimento de seus direitos teve, portanto, que incluir a busca por seu reconhecimento como consumidor, já que, como nos deixam transparecer as 
declarações abaixo, não só sua cidadania, mas também sua existência enquanto componente social estavam, de certa maneira, atreladas ao seu poder aquisitivo.

O diretor de criação Clóvis Calia, por exemplo, dizia ser difícil determinar se a discriminação era racial ou social, mas afirmava que na publicidade o branco era o ponto de referência, e que pelo fato de "todo mundo" saber que o negro ambicionaria as coisas do branco é que o branco seria utilizado para vender para os negros (PIRES, 1988, p.12). E podemos citar também Jacqueline Haas, da agência Almap, que, segundo a revista, havia comprovado por meio de diversas entrevistas que as novas gerações de negros queriam ser brancos por não terem nenhum referencial negro pra se apoiarem (PIRES, 1988, p.14).

Assim, a população negra buscou se afirmar perante o meio publicitário como público consumidor, luta que acabou por gerar resultados: em 1995, a agência Grottera publicou a pesquisa Qual é o pente que te penteia: o perfil do consumidor negro no Brasil ${ }^{49}$. No texto, a agência diz que a população negra, “um segmento de mercado de relevância econômica”, tem dinheiro, tem sonhos de consumo, mas não tem atenção das empresas brasileiras (GROTTERA, 1995, p.2).

Frases como “... do ponto de vista dos negócios, ignorar o negro não é uma questão de preconceito. É burrice” (GROTTERA, 1995, p.2) são encontradas no texto da pesquisa, que apresenta números, tabelas e o resultado de entrevistas para comprovar as suas três "teses": a população negra é quantitativamente grande e tem tido (sic) crescimento significativo na sua renda e poder de consumo; há uma consolidação da classe média negra; e as empresas estão perdendo muitas oportunidades de negócios por não estarem atentas a essa realidade (GROTTERA, 1995, p.3).

Ao longo do texto são inúmeras as referências mercadológicas ao negro, todavia não há nenhuma que aluda à cidadania ou à igualdade. Mas tal característica não é exclusividade dessa pesquisa. Em seu artigo Cabelo, cabeleira, cabeluda, descabelada: Identidade, Consumo e Manipulação da Aparência entre negros brasileros, Ângela Figueiredo apresenta trechos de matérias jornalísticas que trazem como destaque justamente a importância das relações de consumo da população negra (FIGUEIREDO, 2002, p.7-8):

- Jornal da Tarde, 13/10/1996: “... o negro é um consumidor voraz. Ele gasta, por exemplo, mais dinheiro com roupas do que os brancos porque precisa sinalizar a sua condição social...”;

\footnotetext{
${ }^{49}$ A pesquisa da Grottera pode ser considerada um divisor de águas, já que foi a primeira a conferir tamanha importância ao negro enquanto consumidor. Entretanto, pesquisadores como Ângela Figueiredo atribuem a "descoberta do consumidor negro" ao lançamento da Revista Raça, em 1996: "o novo contexto é influenciado pelo lançamento da revista Raça Brasil e, conseqüentemente, pela descoberta do consumidor negro" (FIGUEIREDO, 2002, p.7).
} 
- Carta capital, 26/11/1997: “A cor do dinheiro: As empresas estão investindo nos consumidores negros. Eles são mais de 7 milhões e formam um nicho quase intocado";

- Diário do Comércio, 15/11/2000: “Classe média negra impulsiona a venda de produtos étnicos: A valorização do potencial de consumo dessa parcela da população vai na contramão das suas conquistas sociais. (...) Apesar da desigualdade, o mercado está atento à demanda crescente de uma classe média negra estimada em 8 milhões de pessoas, que gira US\$ 50 bilhões anuais”.

Somos levados então a concordar com Sodré quando este afirma que "houve mesmo, na verdade, a descoberta pelos publicitários de um filão novo de mercado” (SODRÉ, 1999, p.252).

Para o autor, essa “modernização” da publicidade é uma simulação que tem como base a detecção por parte do mercado de "bolsões de renda concentrada", que não significaria uma “verdadeira e digna integração socioeconômica dos descendentes de africanos": "Fora dessa esfera mercadológico-mediática, continua preocupante a condição social dos afrodescendentes, marcada pela desigualdade nos níveis de renda e acesso a serviços de educação, saúde e habitação” (SODRÉ, 1999, p.251).

Essa publicidade “modernizada” apresentaria um discurso sobre o negro mais estético do que político ou ético (SODRÉ, 1999, p.254), de maneira que, se por um lado “detecta-se aspectos integradores na assimilação social do indivíduo escuro baseada na satisfação de desejos de consumo”, por outro "permanece inatacado o problema, o mal-estar civilizatório, do racismo” (SODRÉ, 1999, p.257).

Com efeito, toda essa encenação mercadológica da diferença - onde se assiste à reduplicação do Mesmo hegemônico através do Outro subalterno é fundamentalmente racista. A moral do mercado não engendra a continuidade ético-política do ser, isto é, uma parceria social plena, criadora de respeito em vez de tolerância, entre o afro-descendente e os descendentes privilegiados do patrimonialismo europeu (SODRÉ, 1999, p.257).

Assim, podemos concluir que as constatações que Hasenbalg apresenta em seu artigo pioneiro publicado originalmente em 1982 (As imagens do negro na publicidade), são, guardadas as diferenças de cada período, válidas para o período mais atual:

a) A publicidade não é alheia à dinâmica simbólica que rege as relações raciais no Brasil. Por ação e omissão, ela é instrumento eficaz de perpetuação de uma estética branca carregada de implicações racistas. Nela o negro aparece sub-representado e diminuído como consumidor e como segmento da população do país, reforçando-se assim a tendência fazer dele um ser invisível, "retirado de cena".

b) Nas suas escassas incursões na publicidade, o negro tende a ser dissociado de produtos específicos, o que sugere a estratégia publicitária de evitar a contaminação da imagem desses produtos. Além do mais, suas aparições 
tendem a ficar diluídas e amenizadas pela presença conjunta de representantes do grupo racialmente dominante.

c) A publicidade reproduz os estereótipos culturais sobre o negro, assim contribuindo para delimitar, no plano ideológico, "seus lugares” apropriados. Esses lugares esgotam-se na polaridade trabalho desqualificado/entertainer, “objeto de consumo” (HASENBALG, 1988, p. 187-188).

Por fim, é importante ter em conta que o registro branco do Brasil que vem sendo perpetuado pelo grupo racial hegemônico - segmento que compõe majoritariamente nossa elite logotécnica - é extremamente prejudicial à construção da identidade individual e coletiva dos indivíduos escuros.

Ao permitir que o negro ocupe determinados espaços na mídia (e nos demais espaços de representação), ao mesmo tempo em que o apaga dos demais, nossas elites delimitam simbolicamente quais são os lugares do negro na sociedade. E o confinamento do indivíduo escuro em papéis subalternizantes termina por criar um modelo de identificação deturpado que prejudica sua formação.

Na fase de busca e constituição da identidade a que parcelas expressivas do grupo negro se encontram atualmente, quando a grande massa negra ainda se vê através do espelho ideológico do branco, esta imagem interiorizada pelos próprios membros do grupo é altamente deletéria (BORGES PEREIRA, 1983, p.142).

Da mesma forma, o registro branco do Brasil também concorre para a naturalização do racismo. Uma vez que a estereotipação/invisibilização do negro é constante nos espaços de representação simbólica, os discursos sociais acabam “disciplinados” de tal forma que ambos os grupos são incapazes de perceber a si próprios de maneira diferente à comumente apresentada.

Torna-se então natural que os brancos figurem em posições de prestígio e negros apareçam em posições subalternizadas, e a desigualdade passa a ser vista como algo inato, normal, e não como uma faceta conflitiva da sociedade que precisa ser pensada.

A publicidade e mídia como um todo atuariam, portanto, negativamente no que concerne à auto-estima e à identidade da parcela negra da população, dificultando a formação de um modelo identitário que permita ao grupo negro pensar sua inserção na estrutura social brasileira em pé de igualdade com o grupo branco. 


\section{REFERÊNCIAS BIBLIOGRÁFICAS}

ANDERSON, Benedict. Comunidades Imaginadas. São Paulo: Cia. Da Letras, 2008.

ANDREWS, George. Negros e Brancos em São Paulo (1888-1988). Bauru: EDUSC, 1998.

ARAÚJO, Joel Zito. A Negação do Brasil: o negro na telenovela brasileira. São Paulo: SENAC, 2000.

A força de um desejo: a persistência da branquitude como padrão estético audiovisual.Revista USP, São Paulo, nº 69, p.72-79, 2006.

AZEVEDO, Aloísio. O cortiço. Rio de Janeiro, 1890. Disponível em: <www.dominiopubl ico.gov.br/pesquisa/DetalheObraForm.do?select_action=\&co_obra=1723> Acesso em: 10 mar. 2009.

AZEVEDO, Célia Maria Marinho de. Abolicionismo: Estados Unidos e Brasil, uma história comparada - século XIX. São Paulo: Annablume, 2003.

Onda Negra, Medo Branco: o negro no imaginário das elites - século XIX. São Paulo: Annablume, 2004.

BACCI, Massimo Livi. 500 Anos de Demografia Brasileira: uma resenha. Revista Brasileira de Estudos de População, v.19, n.1, 2002. Disponível em: <http://www.abep. nepo.unicamp.br/docs/rev_inf/vol19_n1_2002/vol19_n1_2002_8pontodevista_141_159.pdf> Acesso em: 08 jan. 2009.

BASTIDE, Roger. O negro na imprensa e na literatura. São Paulo: ECA-USP, 1972.

BIGAL, Solange. O que é criação publicitária (ou o estético na publicidade). São Paulo: Nobel, 1999.

BOBBIO, Norberto; MATEUCCI, Nicola; PASQUINO, Gianfranco. Dicionário de Política. Brasília: UNB, 1998.

BORGES PEREIRA, João Baptista. Comunicação social e representação étnica. Revista Comunicação e Sociedade, São Bernardo do Campo, nº 9, p. 138-145, 1983.

Cor, Profissão e Mobilidade: o negro e o rádio de São Paulo. 2a ed. São Paulo: EDUSP, 2001.

BOSI, Ecléa. Entre a opinião e o estereótipo. In: O tempo vivo da memória. São Paulo: $Æ$ Editorial, 2004.

BROOKSHAW, David. Raça \& cor na literatura brasileira. Porto Alegre: Mercado Aberto, 1983.

CAMARGO, Alberto Mesquita. Antologia Literária. São Paulo: IAMC, 1993. 
CANCLÍNI, Néstor Garcia. Consumidores e Cidadãos: conflitos multiculturais da globalização. Rio de Janeiro: Editora UFRJ, 2001.

CANEVACCI, Massimo. Antropologia da Comunicação Visual. São Paulo: Brasiliense, 1990.

CORRÊA, Laura Guimarães. De corpo presente: o negro na publicidade. Dissertação de Mestrado. Universidade Federal de Minas Gerais, 2006.

COUCEIRO DE LIMA, Solange Martins. O Negro na Televisão de São Paulo: um estudo de relações raciais. São Paulo: FFLCH-USP, 1983.

Mulher e Família Negras: realidade e representação na obra de Nina Rodrigues. Tese de Doutorado. ECA-USP, São Paulo, 1984.

. Preconceito anunciado. Comunicação e Artes, São Paulo, nº 27, p. 17-19, 1992.

1995.

A Publicidade e os símbolos raciais. Revista Comunicação e Educação, p. 91-93, ....até canibal vira vegetariano. Revista USP, São Paulo, nº 69, p.44-59, 2006.

D’ADESKY, Jacques. Pluralismo Étnico e Multi-Culturalismo: racismos e anti-racismos no Brasil. Rio de Janeiro: Pallas, 2001.

DALLARI, Dalmo de Abreu. Direitos Humanos e Cidadania. $2^{\text {a }}$ Ed. São Paulo: Moderna. $\mathrm{n} / \mathrm{d}$.

DOMINGUES, Petrônio. Uma história não contada: negro, racismo e branqueamento em São Paulo no pós-abolição. São Paulo: SENAC, 2003.

FIGUEIREDO, Ângela. Cabelo, cabeleira, cabeluda, descabelada: Identidade, Consumo e Manipulação da Aparência entre negros brasileiros. In: Reunião da Associação Nacional de Pós-Graduação e Pesquisa em Ciências Sociais, XXVI. Anais... Caxambu: ANPOCS, 2002.

FREYRE, Gilberto. O escravo nos anúncios de jornais brasileiros do século XIX. São Paulo: Castelo Branco e Associados Propaganda, 1984.

GOFFMAN, Erving. Estigma. 2a ed. Rio de Janeiro: Zahar, 1978.

HALL, Stuart. Quem precisa da identidade. In: SILVA, Tomaz Tadeu (org). Identidade e Diferença: a perspectiva dos Estudos Culturais. Petrópolis: Vozes, 2000. p. 103-133.

A identidade Cultural na Pós-Modernidade. 10ª ed. São Paulo: DP\&A, 2005.

2006.

Da diáspora: identidades e mediações culturais. Belo Horizonte: Editora UFMG,

HASENBALG, Carlos A. As imagens do negro na publicidade. In: ; SILVA, Nelson Valle. Estrutura Social, Mobilidade e Raça. São Paulo: Vértice, 1988. p. 183-200. 
JACCORD, Luciana. Racismo e República: o debate sobre o branqueamento e a discriminação racial no Brasil. In: THEODORO, Mário (org.). As políticas públicas e a desigualdade racial no Brasil 120 anos após a abolição. Brasília: IPEA, 2008.

JANCSÓ, Istvan; PIMENTA, João Paulo G. Peças de um mosaico. Revista de História das Idéias. Coimbra, Vol. 21, 2000.

KELLNER, Douglas. A Cultura da Mídia. Bauru: EDUSC, 2001.

LEITE, Francisco Vanildo. Comunicação e cognição: os efeitos da propaganda contraintuitiva no deslocamento de crenças e estereótipos. Ciências \& Cognição, v.13, p.131-141, 2008. Disponível em: <http://www.cienciasecognicao.org/pdf/v13/cec_v13-1_m318223.pdf> Acesso em: 21 out. 2009.

LIMA, Marcus; PEREIRA, Marcos (org.). Estereótipos, Preconceitos e Discriminação: perspectivas teóricas e metodológicas. Salvador: EDUFBA, 2004.

LOPES, Maria Immacolata Vassalo de. Pesquisa em Comunicação. $8^{a}$ ed. São Paulo: Loyola, 2005.

MARTINS, Maria Cristina da Silva. A Personagem Afro-Descendente no Espelho Publicitário de Imagem Fixa. Tese de Doutorado. PUC-SP, São Paulo, 2000.

MENDES, Miriam Garcia. A personagem negra no teatro brasileiro. São Paulo: Ática, 1982.

MÉRIAN, Jean-Yves. O negro na literatura brasileira versus uma literatura afro-brasileira: mito e literatura. Navegações, Porto Alegre, v.1, $\mathrm{n}^{0}$ 1, p.50-60, 2008. Disponível em: $<$ http://revistaseletronicas.pucrs.br/ojs/index.php/navegacoes/article/viewFile/3684/2834> Acessado: 04 jun. 2009.

MOEHLECKE, Sabrina. Ação Afirmativa: história e debates no Brasil. Cadernos de Pesquisa, São Paulo n. 117, 2002. Disponível em: <http://www.scielo.br/pdf/cp/n117/ 15559.pdf> Acesso: 20 mai. 2008.

MOURA, Clóvis. Sociologia do Negro Brasileiro. São Paulo: Ática, 1988.

MUNANGA, Kabengele. Rediscutindo a Mestiçagem no Brasil. Petrópolis: Vozes, 1999.

NABUCO, Joaquim. O Abolicionismo. 1883. Disponível em: <http://www.bibvirt.futuro. usp.br/index.php/content/view/full/1854> Acesso em: 28 jan. 2009.

ORLANDI, Eni. As Formas do silêncio. Campinas: UNICAMP, 1997.

ORTIZ, Renato. A Moderna Tradição Brasileira. 5ª ed. São Paulo: Brasiliense, 2001.

PINHEIRO, Luana et al. Retrato das desigualdades de raça e gênero. $3^{\mathrm{a}}$ ed. Brasília: IPEA, 2008. 1 CD-ROM. 
PIRES, Renato. O negro como modelo publicitário. Revista Propaganda, São Paulo, $\mathrm{n}^{\circ}$ 40, p.10-18, 1988.

PROENÇA FILHO, Domício. A trajetória do negro na literatura brasileira. Estudos Avançados, São Paulo, $\mathrm{n}^{\circ}$ 18, p. 161-193, 2004. Disponível em: <http://www. scielo.br/pdf/ea/v18n50/a17v1850.pdf> Acessado: 05 mar. 2009.

QUEIROZ JÚNIOR, Teófilo. Preconceito de Cor e a Mulata na Literatura Brasileira. São Paulo: Ática, 1975.

RAMOS, Silvia (org). Mídia e Racismo. Rio de Janeiro: Pallas, 2002.

RODRIGUES, João Carlos. O Negro e o Cinema Brasileiro. Rio de Jandeiro: Pallas, 2001.

SANTOS, Gislene Aparecida dos. A Invenção do Ser Negro: um percurso das idéias que naturalizaram a inferioridade dos negros. São Paulo: Pallas, 2002.

SCWARCZ, Lilia Moritz. Retrato em Branco e Negro: jornais, escravos e cidadania em São Paulo ao final do século XIX. São Paulo: Cia das Letras, 2001.

O Espetáculo das Raças: cientistas, instituições e a questão racial no Brasil 1870/1930. São Paulo: Cia das Letras, 2008.

Romantismo tropical ou o Imperador e seu círculo ilustrado. XXII Colóquio ANPOCS, XXII. Anais Eletrônicos... Caxambu: ANPOCS, 1998. Disponível em: <http://bibliotecavirtual.clacso.org.ar/ar/libros/anpocs/moritz.rtf> Acesso em: 02 jan. 2009.

SEYFERTH, Giralda. João Batista de Lacerda: a antropologia física e a tese do branqueamento da raça no Brasil (mimeo).

SILVA, Tomaz Tadeu. A produção social da identidade e da diferença. In: (org.). Identidade e Diferença: a perspectiva dos estudos culturais. Petrópolis: Vozes, 2000.

SODRÉ, Muniz. Claros e Escuros: identidade, povo e mídia no Brasil. Petrópolis: Vozes, 1999.

STROZENBERG, Ilana. O apelo da cor: percepções dos consumidores sobre as imagens da diferença racial na propaganda brasileira. Comunicação, Mídia e Consumo, São Paulo, $n^{0} 4$, p. 199-220, 2005.

SUBERVI-VELEZ, Federico A.; OLIVEIRA, Omar Souki. Negros (e outras etnias) em comerciais da televisão brasileira: uma investigação exploratória. Revista Comunicação e Sociedade, São Bernardo do Campo, nº 17, 1991.

THEODORO, Mário. A formação do mercado de trabalho e a questão racial no Brasil. In: THEODORO, Mário (org.). As políticas públicas e a desigualdade racial no Brasil 120 anos após a abolição. Brasília: IPEA, 2008.

TOSCANI, Oliviero. A Publicidade É um Cadáver que Nos Sorri. $2^{\text {a }}$ ed. Rio de Janeiro: Ediouro, 1996. 


\section{IMAGENS}

Figura 1 - Illustration of Gall's phrenological system. In: BARKER II, Fred. Phineas among the phrenologists... Journal Neurosurg, volume 82, p. 672-682. Abril-1995. Disponível em: <http://www.jnsonline.org/jns/issues/v82n4/pdf/n0820672.pdf> Acesso em: 05 jan 2009.

Figura 2 - SCHWARCZ, Lilia. Moritz. O Espetáculo das Raças: cientistas, instituições e a questão racial no Brasil - 1870/1930. São Paulo: Cia das Letras, 2008.

Figura 3 - FREYRE, Gilberto. $O$ escravo nos anúncios de jornais brasileiros do século XIX. São Paulo: Castelo Branco e Associados Propaganda, 1984. 